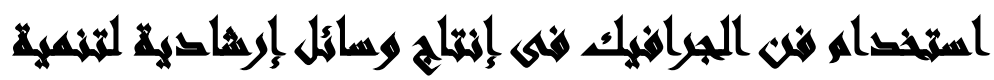

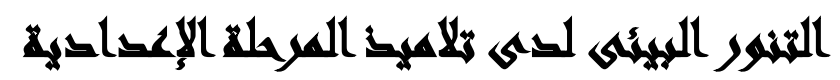

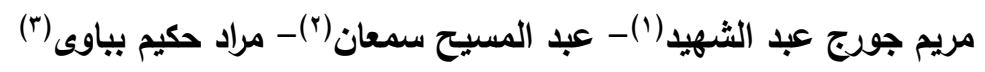

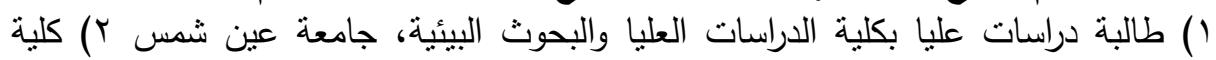

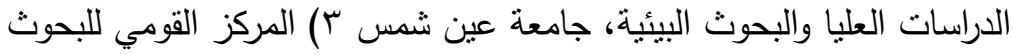

\section{المسترلت}

هدف البحث إلى تتمية التتور البيئى من خلاد استخدام فن الجرافيك لتلاميذ المرحلة

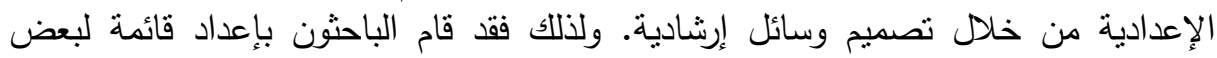

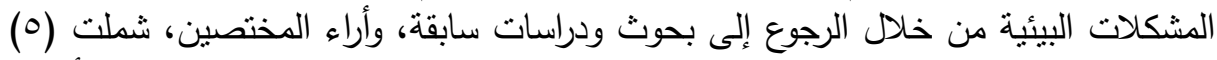

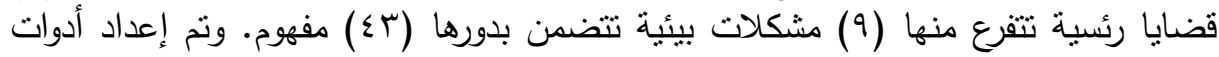

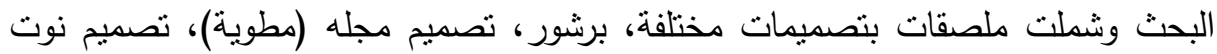

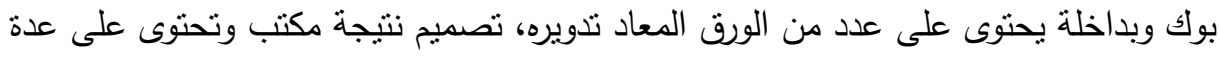

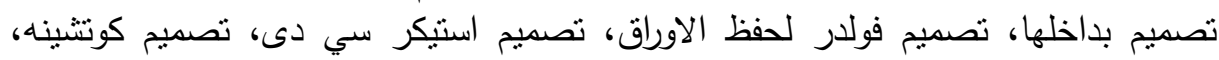

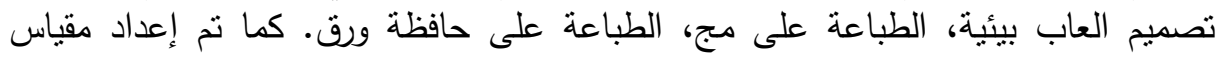
للتنور البيئي اشتمل على (اختبار المعلومات البيئية، ومقياس للاتلجاهاتيات البياتئية ومقياس

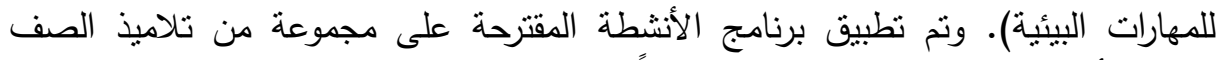

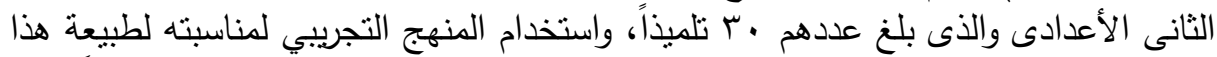

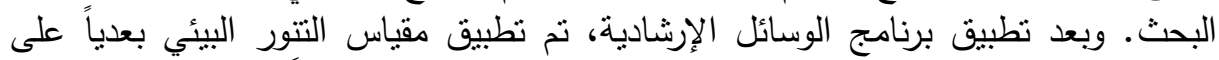

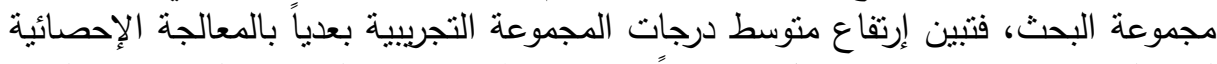

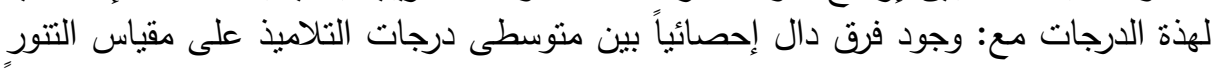

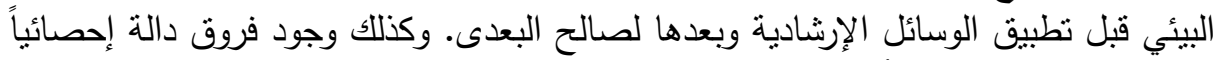

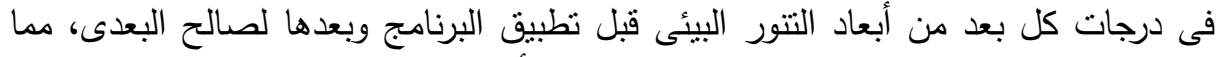

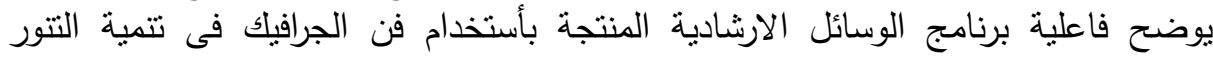

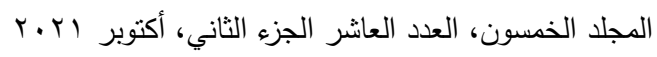

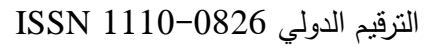

$$
\begin{aligned}
& \text { الترقيم الدولي الموحد الإلكتروني 3178-2636-26 }
\end{aligned}
$$




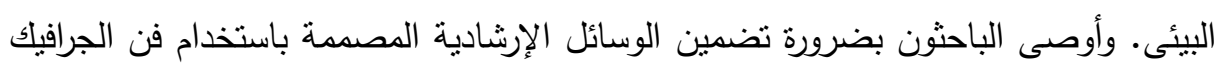

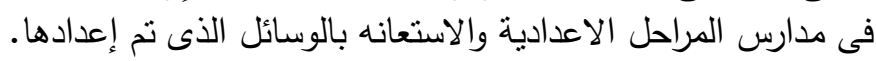
الكلمات المفتاحية: فن الجرافيك - التنور البيئى - الوسائل الإنياتئل الأشادية.

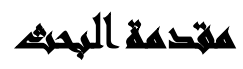

يتميز العصر الذى نعيش فيه بالتغيرات السريعة والتطورات المتلاحقة فى كافة مجالات

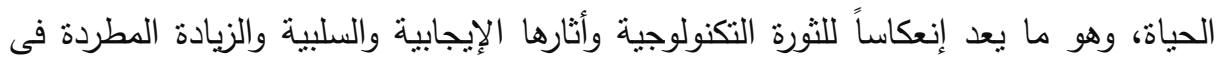
المعرفة العلمية، وهذا ما يشير الى مدى التقدم السريع الذى يعيشه الإنسان، والذى يلقى بظلاله على البيئة بدرجة من الخطورة،مما يؤثر على بقاء الإنسان وصحته وإنتاجه وموارده،

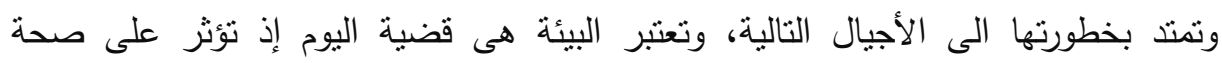

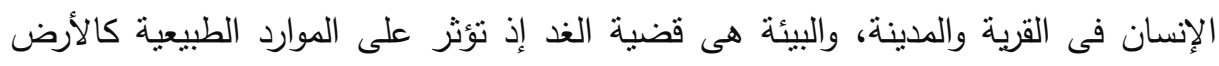

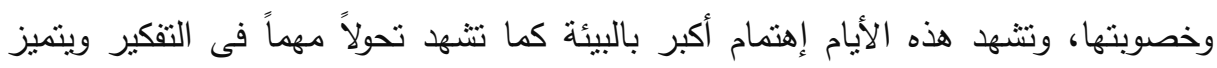
العصر الحالى بتزايد المتغيرات التى تحدثها الثورة العلمية والتكنولوجية فى البيئة، وتعدد أثارها

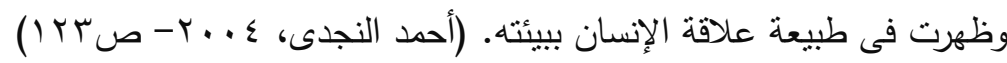
فلابد للإنسان أن يحقق علاقة منوازنة بين التتمية والبيئة، فتسير التتمية وفق الئنس المعدلات المطلوبة، وفى نفس الوقت لا تحدث هذه التتمية أية مشكلات أو أضرار بالبيئة، إنها المعادلة

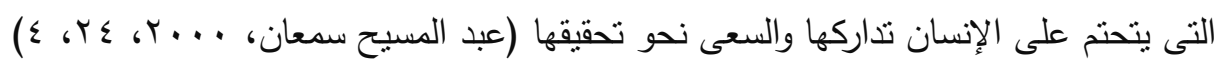
ويهدف النتور البيئى إلى تزويد الفرد بالمفاهيم والمهارات والقيم التى تساعده على على مواجهة المواقف البيئية وذلك بإعتباره مطلباً عصريا يكون فيه كل مواطن قادراً على مواجهة تحدياته

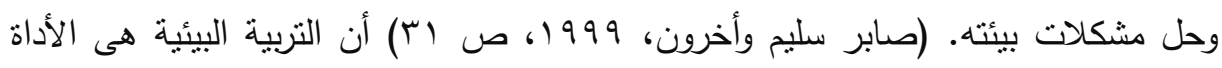
لتحقيق التتور البيئى، وحدد عناصر التتور البيئى التى ينبغى تتميتها فى (الإحساس البيئى -

المعرفة - المهارات - الأتجاهات - القيم -المسئولية الثخصية (Weiser, 2011, p. 65) 386

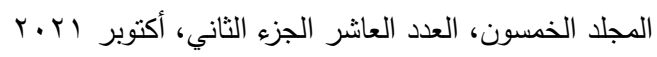

$$
\begin{aligned}
& \text { الترقيم الدولي 0826-1110 } \\
& \text { الترقيم الدولي الموحد الإكتروني 3178-2636 }
\end{aligned}
$$


وتعتبر الأنشطة ركيزة أساسية من ركائز العملية التعليمية فى بناء شخصية التلميذ عبر المسيرة التعليمية فهى تهدف الى تتمبة الفرد عقليا ووجدانياً وجسمياً واجنماعياً لإعداده للحياة

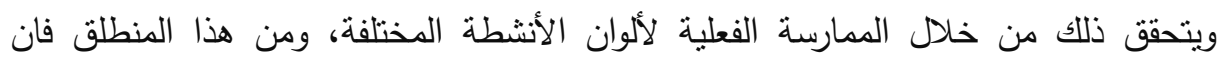

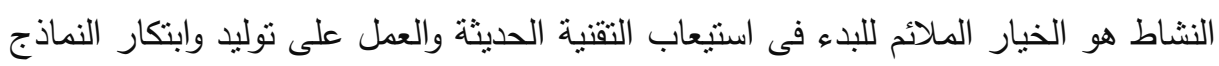
الجديدة وفق منطلبات الحياة فى المجنمع، وبهذا الصدد يشار إلى الأنشطة أنها تلك البرامج

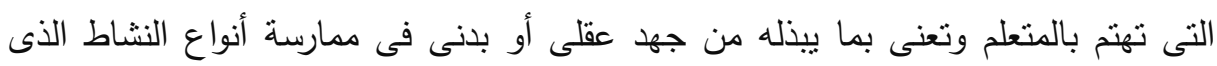

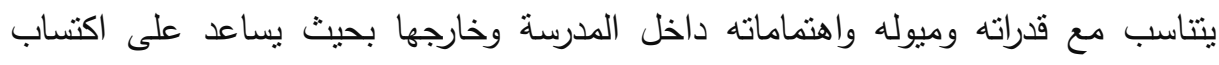

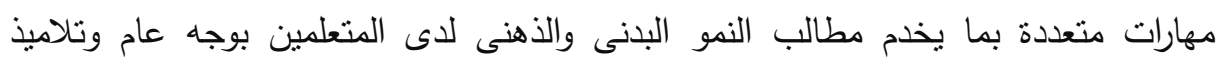

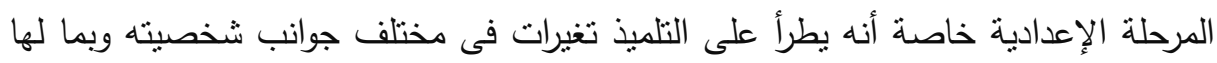
من انعكاس واضح على سلوكه وأفعاله يجعل منها مرحلة مناسبة لاكسابه معارف وسلوكيات

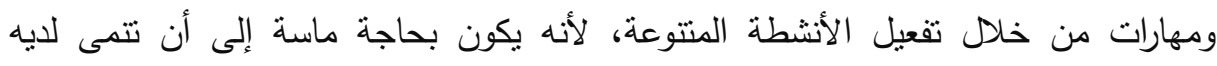

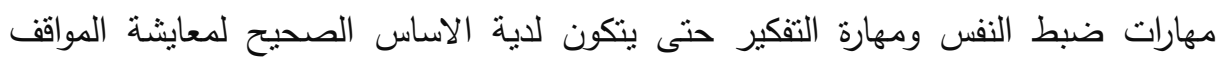

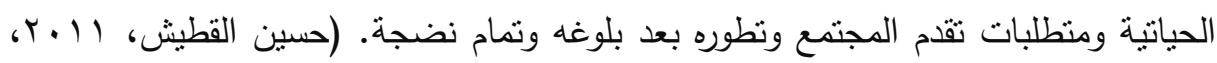

ويعد فن الجرافيك من الفنون التى تساعد على الحس والإدراك المجتمعى للبيئة المفترض

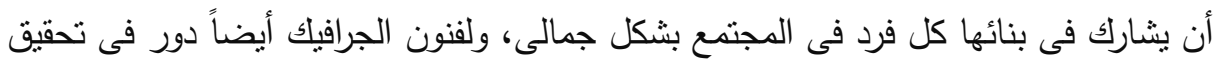
التتور البيئى لدى الإنسان ومجتمعه وذلك عن طريق الأنغماس فى العملية الفنية حيث يبدأ

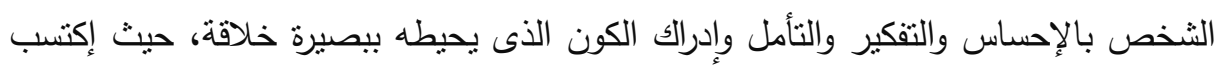

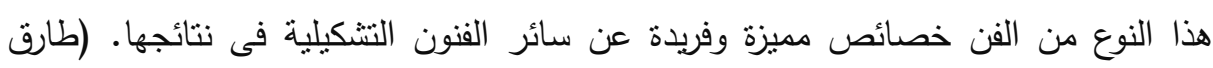

$$
\begin{aligned}
& \text { المجلد الخمسون، العدد العاشر الجزء الثاني، أكتوبر ب r.r. }
\end{aligned}
$$

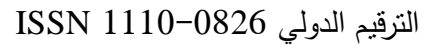

$$
\begin{aligned}
& \text { الترقيم الدولي الموحد الإلكتروني 3178-2636-26 التربي }
\end{aligned}
$$


ويؤدى المصمم فى هذا المجال دوراً بالغ الأهمية، بحيث بمكن أن يكون حافزاً إيجابياً

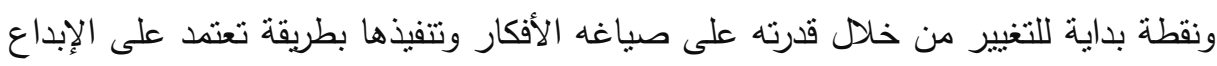

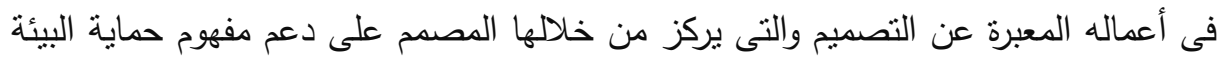

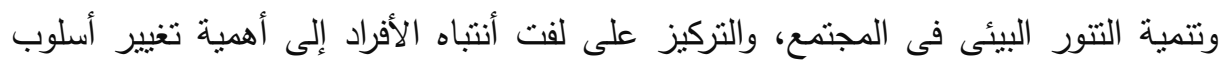

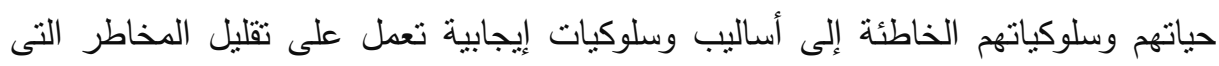

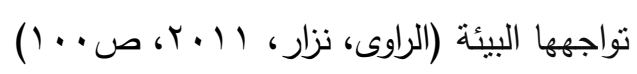

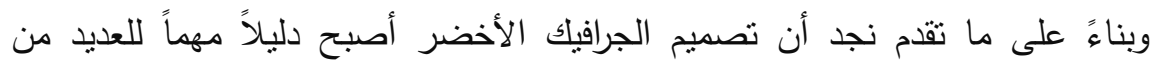

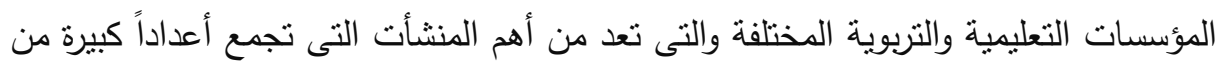

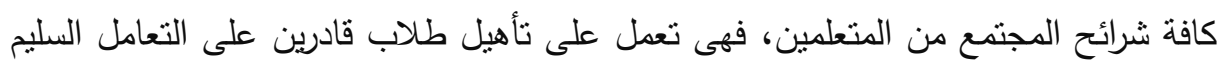

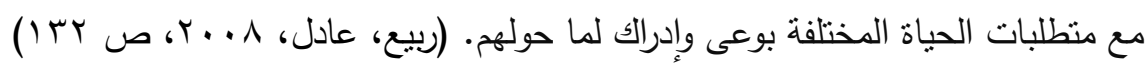

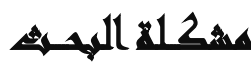

قام الباحثون باجراء دراسة أستطلاعية بتطبيق مقياس التتور البيئى (ميلاد وليم -

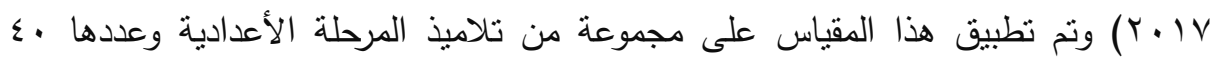

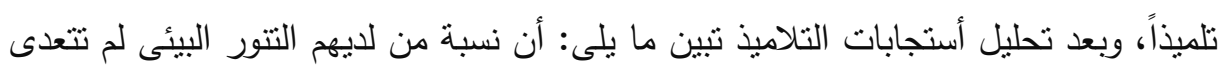

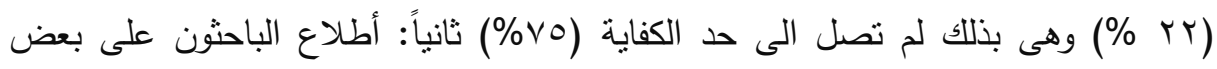

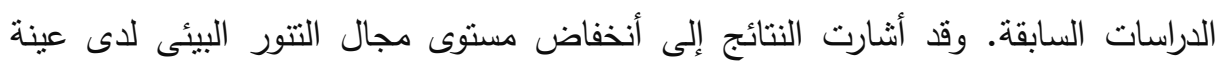

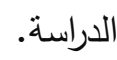

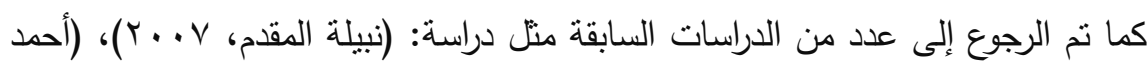

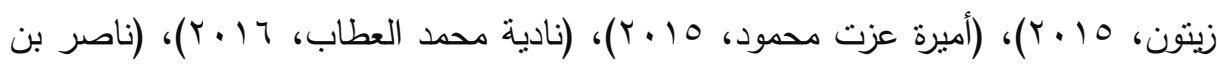

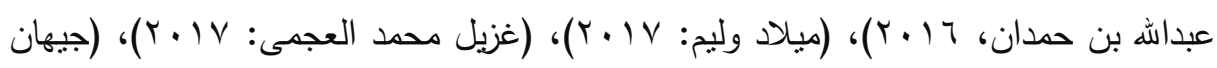

$$
\begin{aligned}
& \text { المجلد الخمسون، العدد العاشر الجزء الثاني، أكتوبر ب r.r. } \\
& \text { التزقيم الدولي 0826- ISSN 1110 } \\
& \text { الترقيم الدولي الموحد الإكتروني 3178-2636 }
\end{aligned}
$$




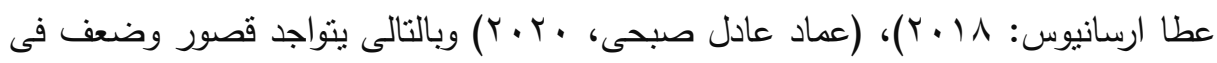
التنور البيئي لدى تلاميذ المرحلة الإعدادية.

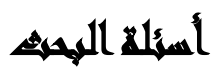

ما فاعلية إستخدام فن الجرافيك من إنتاج وسائل إرشادية على تتمية التتور البيئى لدى تلاميذ المرحلة الأعدادية؟ مأبه

ويتفرع من هذا السؤال الأسئلة التالية: ا ـ ما القضايا البيئية التى يجب أن ينت التتور بها لإى تلاميذ المرحلة الأعدادية؟

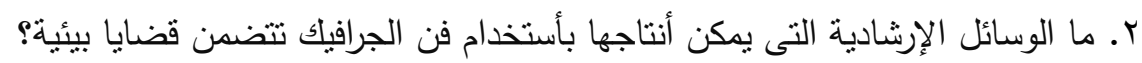

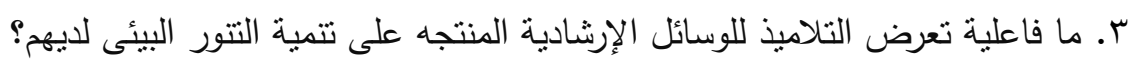

\section{هورغ الهميث}

الفرض الرئيسي: يوجد فرق دال إحصائياً بين متوسطى درجات تلاميذ المجموعة التجريبية (عينة البحث) فى مقياس التنور البيئى قبل ويعد تعرضهم لبرنامج الوسائل

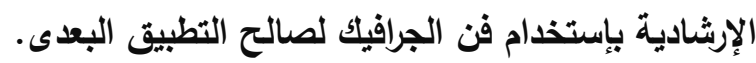

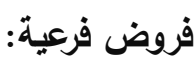
أ- يوجد فرق دال إحصائياً عند مستوى دلالة (0. . •) بين منوسطى درجات اختبار المعارف

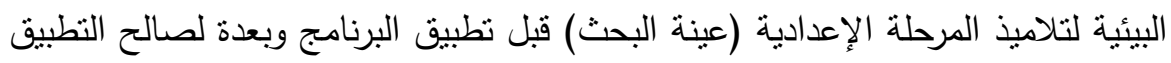

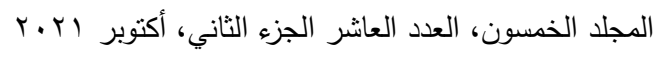

$$
\begin{aligned}
& \text { الترقيم الدولي 0826-1110 } \\
& \text { الترقيم الدولي الموحد الإلكتروني 3178-2636-26 }
\end{aligned}
$$


ب- بوجد فرق دال إحصائياً عند مستوى دلالة (0., ·) بين متوسطى درجات مقياس

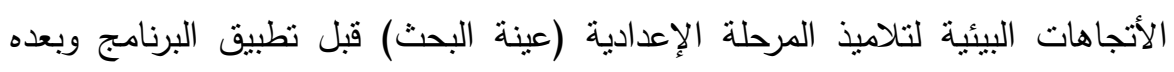

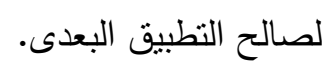

ج- يوجد فرق دال إحصائياً عند مستوى دلالة (0.,.) بين متوسطى درجات مقياس

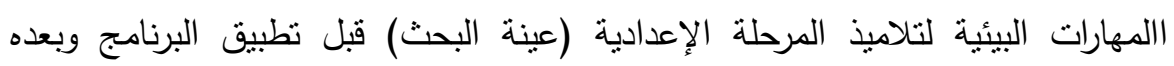

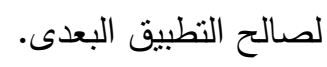

\section{هـ}

يهدف البحث الحالى إلى: تتمية التتور البيئى لتلاميذ المرحلة الإعدادية من خلال الوسائل الأشنادية بأستخدام فن الجرافيك.

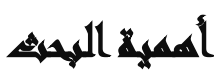

ترجع أهمية البحث الحالى إلى مدى أستفادة الفئات التالية منه:

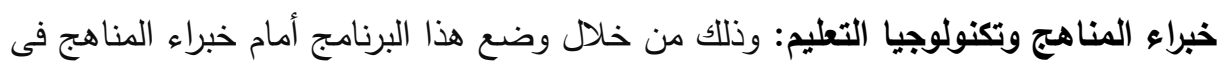

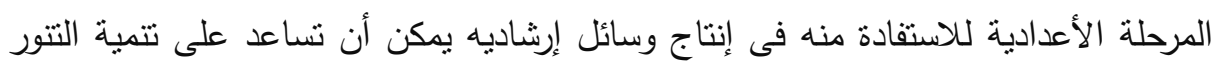
البيئى لدى التلاميذ. المعلمون: وذلك من خلال إستفادتهم فى كيفية تتمية بعض عناصر التتور البيئى لاى التناميذ. الباحثون: وذلك من خلال إستفادتهم مما يقدمه البحث الحالى من أدوات التجريب (الوسائل الأرشادية من خلال برامج الجرافيك) وأدوات القياس وتتمنل فى مقياس النتور البيأى.

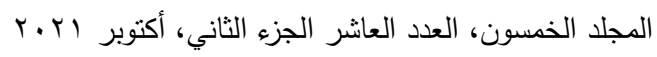

$$
\begin{aligned}
& \text { الترقيم الدولي 0826-1110 } \\
& \text { الترقيم الدولي الموحد الإلكتروني 3178-2636-26 }
\end{aligned}
$$


مجلة العلوم البيئية

كلية الدراسات العليا والبحوث البيئية - جامعة عين شمس البئة

مريم جورج عبد الثهيد وآخرون

\section{مسوت اللهمهر}

حدود بشــرية: نلاميذ الصف الثانى بالمرحلة الإعدادية. حدود موضوعية: استخدام برنامج جرافيك (فوتوشوب) • r، (اليستريتور)، (وورد). حدود مكــانية: مدرسة سويت هوم الإعدادية إدارة شبرا التعليمية.

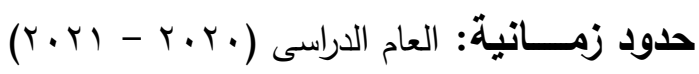

\section{منهمج المهيث}

المنهج التجـريبي: وذللك لتجريب الوسائل الإرشادية على مجموعة من تلاميذ الصف الثانى الإعدادى وذللك بأستخدام التصميم التجريبي القائم على تصميم مجموعة تجريبية واحدة وإجراء النطبيق القبلى والبعدى لآدوات القياس ممثلة فى (مقياس المعلومات البيئية - مقياس الاتجاهات البيئية - مقياس المهارات البيئية).

\section{مسطلحاهي الهمبث}

فن الجرافيك: أنه مجموعة التقنيات المستخدمة لتحليل وتفسير الحقائق من خلال الخطوط

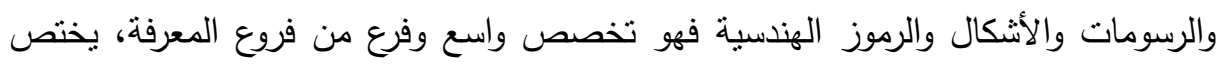

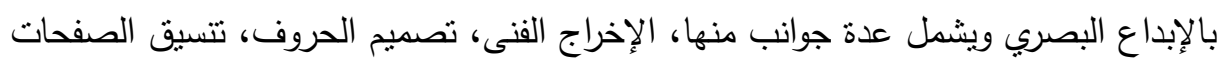

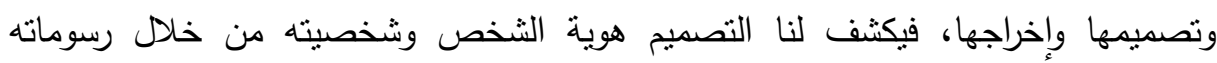

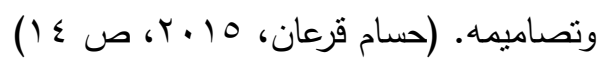
الوسائل الإرشادية: كل نشاط يقوم به المدرس سواء كان هذا النشاط داخل المدرسة أو أو خارجها، طالما أنه يتم تحت إثراف المدرسة وبتوجيه منها ويقع هذا النشاط فى صميم المنهج

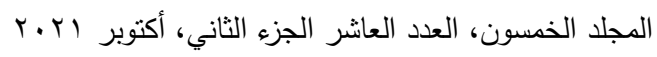

$$
\begin{aligned}
& \text { الترقيم الدولي 0826-1110 } \\
& \text { الترقيم الدولي الموحد الإلكتروني 3178-2636-26 التربي }
\end{aligned}
$$


وليس على هامثه، إذ أنه يهيئ للطلاب خبرات منتوعة، كما أنه يزيد خبرات المنهج وضوحاً

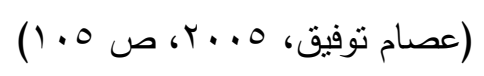

التصميم الجرافيكى: هو نشاط إتصالى مرئى يتحقق عبر خبرة المصدم فى التعبير والقدرة على التصور والتخيل والأبتكار عن طريق المهارة فى التعبير عن الأفكار والرؤى المختلفة

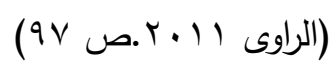

التتور البيئى: انه إكتساب المعلم لقدر من المعارف عن البيئة ومفاهيمها ونظمها ومثكلاتها، تؤدى به إلى تكوين وعى وإتجاهات إيجابية ليتعامل مع البيئة ويتخذ قرارات

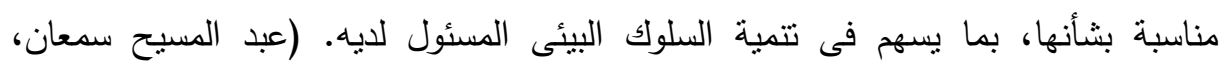

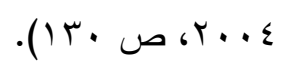

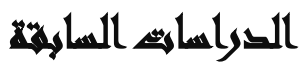

نم تتاولها من خلال المحاور التالية: المحور الأول: التتور البيئي:

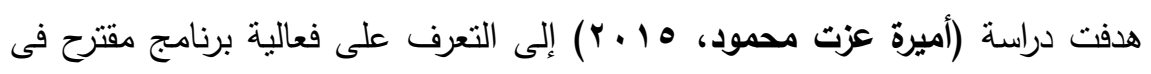

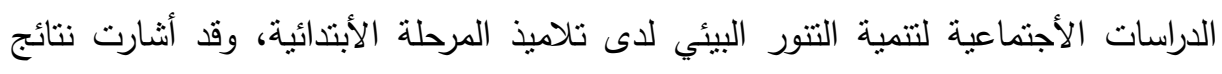

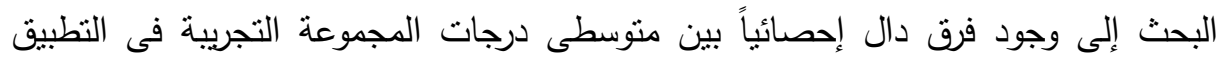
القبلى والبعدى لمقياس التتور لصالح التطبيق البعدى، مما يؤكد على فعالية البرنامج المقترح فى الدراسات الأجتماعية لتتمية التتور البيئي لدى تلاميذ المرحلة الأبتدائية.

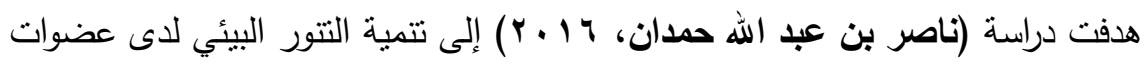

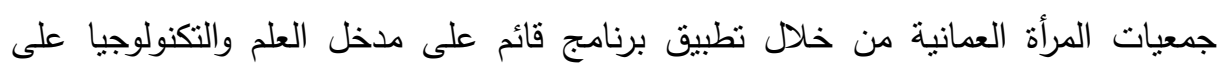

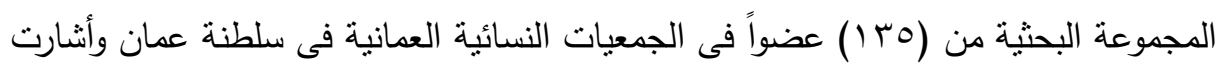
392

$$
\begin{aligned}
& \text { المجلد الخمسون، العدد العاشر الجزء الثاني، أكتوبر ب r.r. }
\end{aligned}
$$

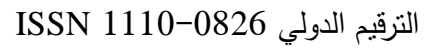

$$
\begin{aligned}
& \text { الترقيم الدولي الموحد الإلكتروني 3178-2636 }
\end{aligned}
$$


نتائج البحث إلى أن البرنامج المقترح يعتمد على فاعلية مدخل العلوم والتكنولوجيا والمجتمع

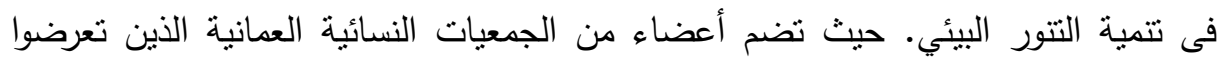
للبرنامج.

وتتاولت دراسة (نادية محمد العطاب، 17 • ب) فعالية مقرر التربية البيئية فى تحقيق أهداف التتور البيئي من خلال مقياس للمفاهيم البيئية الذى طبق على عينة قوامها (70) مفردة، وجاءت نتائج التطبيق فى الفرق بين المتوسطين لدرجات المقياس لصالح التطبيق

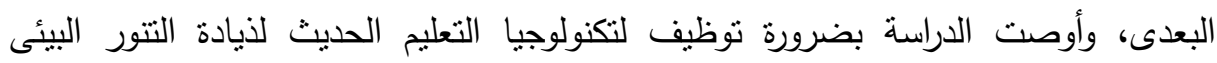
والوعى بالقضايا البيئية.

دراسة (Emmanuel Chukwuemeka, 2017)

تم جمع البيانات من طلاب جامعتين حكوميتين وجامعتين خاصتين ثم اختبار عينة من

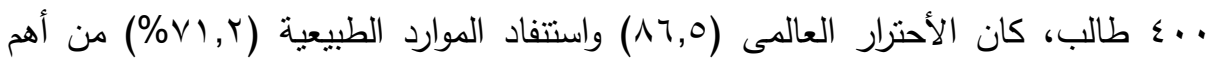

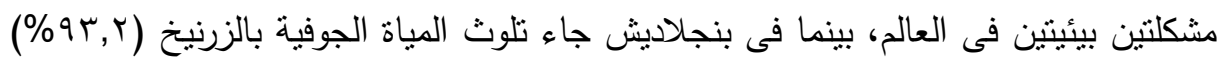

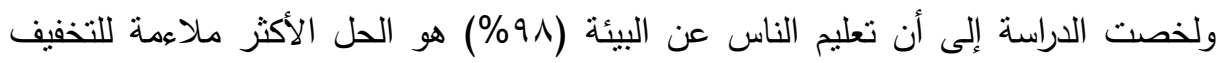

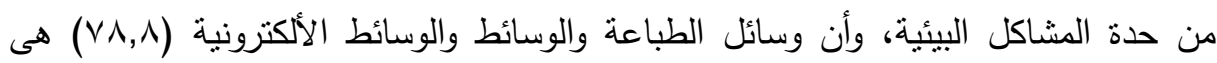

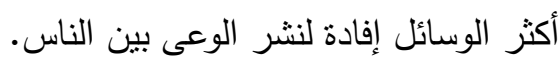
كشفت دراسة ( Lioyd-Strovas et al., 2018

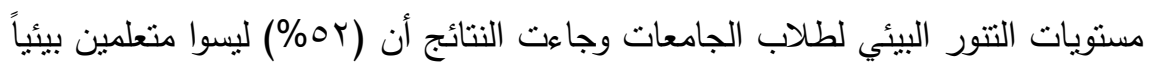

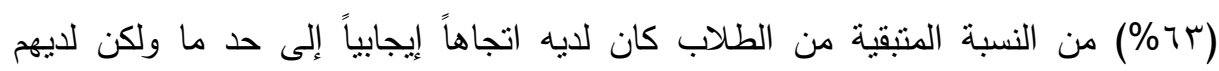
مستويات منخفضة من التتور البيئى والمعرفة (

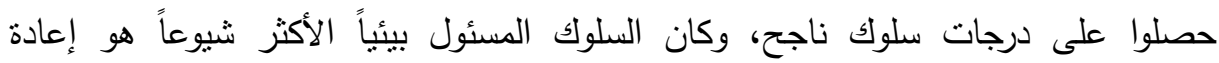

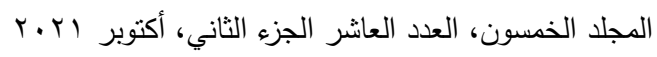

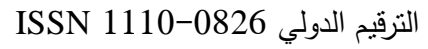

$$
\begin{aligned}
& \text { الترقيم الدولي الموحد الإلكتروني 3178-2636-26 }
\end{aligned}
$$


التدوير، والأكثر ندرة هو رفض قبول اكياس التسوق البلاستيكية ولخصت الدراسة على أنه من

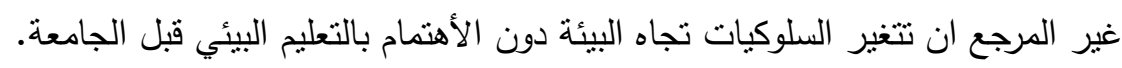

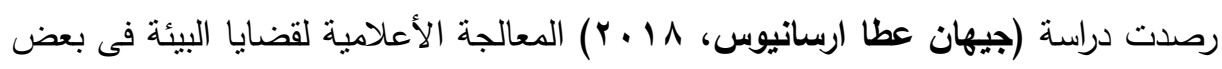
المواقع الألكترونية للمؤسسات الصحفية، حيث تم تطبيق مقياس المسئولية البيئية على عينة

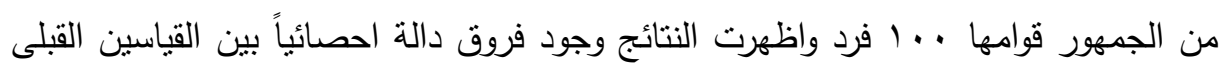

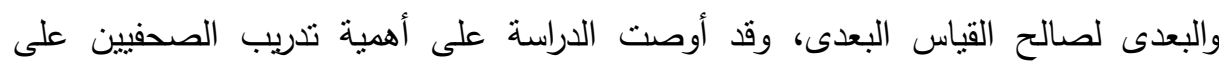

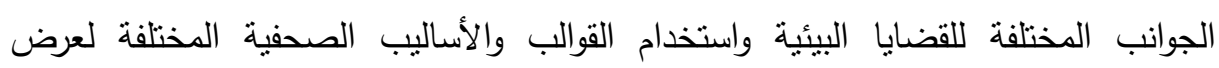
القضايا بطرق أكثر ثأثيراً.

(Emam Gheit, 2019)

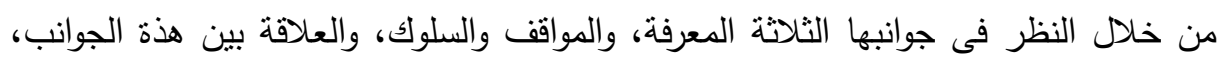

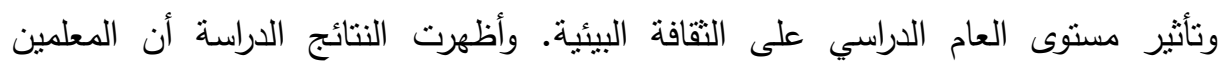

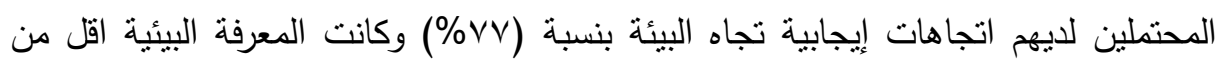
المستوى المقبول حيث بلغت (V,V) كما أن مستوى السلوك البيئي كان أقل من المستوى

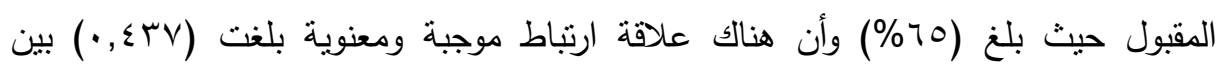
اتجاهات الطلاب تجاه البيئة وسلوكهم.

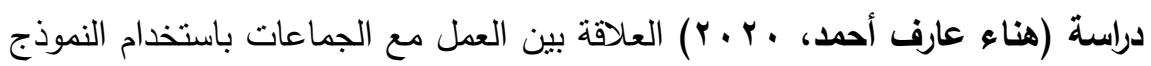

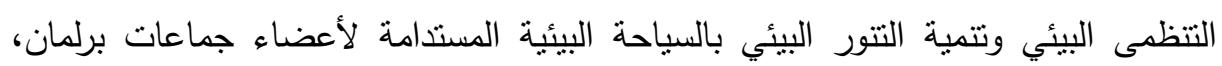

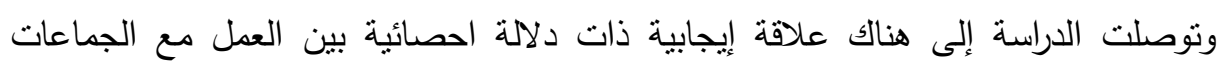
بأستخدام النموذج التتظيمى البيئي وتتمية الجانب (المعرفى، القيمى، المهارى).

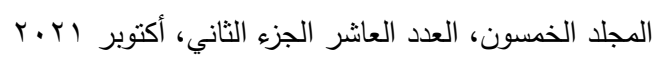

$$
\begin{aligned}
& \text { الترقيم الدولي 0826-08S 1110 } \\
& \text { الترقيم الدولي الموحد الإكتروني 3178-2636 }
\end{aligned}
$$




\section{مجلة العلوم البيئية \\ كلية الدراسات العليا والبحوث البيئية - جامعة عين شمس لهـ \\ مريم جورج عبد الثهيد وآخرون}

المحور الثانى: الاراسات المتعلقة بالأنشطة: هدفت الدراسة إلى اشتراك التلاميذ فى الأنشطة المصاحبة (Jennifer Gibbons, 2016)

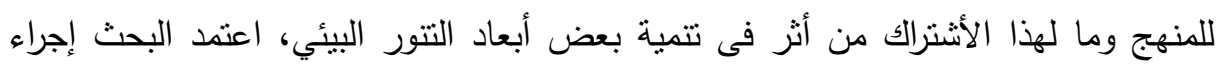

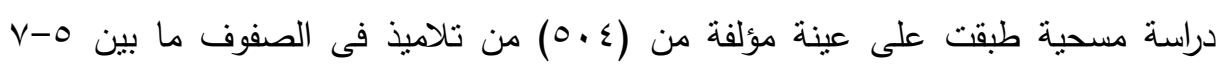

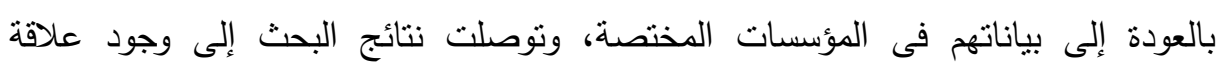

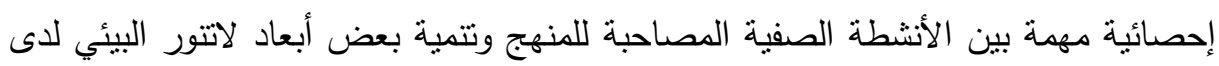
تلاميذ المراحل الدراسية المتوسطة.

أثنار البحث إلى تعرف أثز مشاركة تلاميذ الرحلة (David, J. Shermaff, 2018) المتوسطة فى برامج الأنشطة خارج المدرسة على مستوى خبراتهم الذاتية والاكاديمية واستخدام

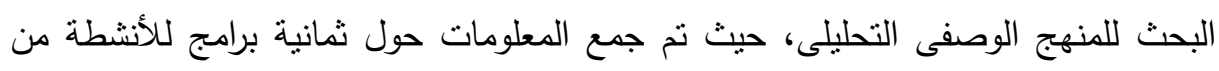

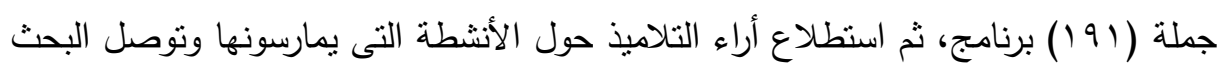

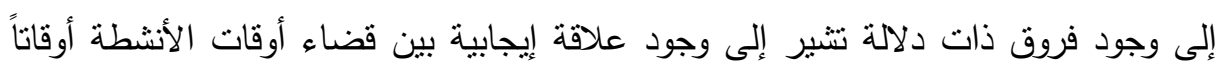

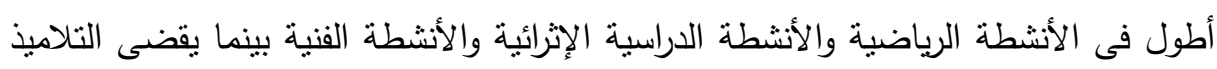

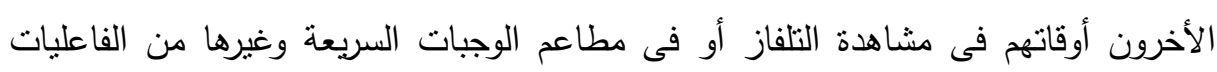

المشابهة.

المحور الثالث: الدراسات المتعلقة بفن الجرافيك:

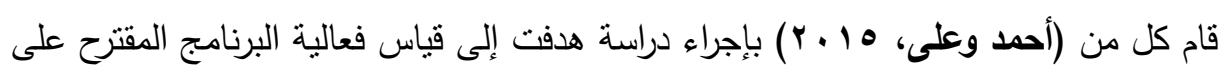
تتمية بعض مهارات تصميم ملصق إعلانى للوعى البيئي وإبراز دور الملصق الإعلانى

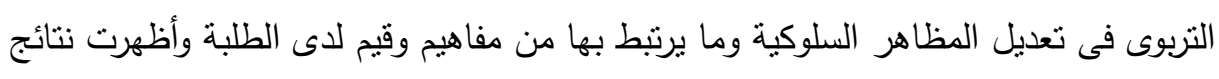

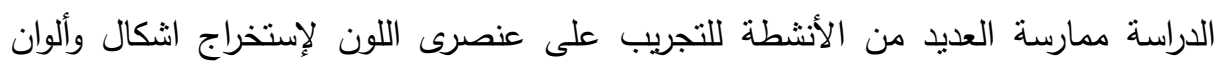

$$
\begin{aligned}
& \text { المجلد الخمسون، العدد العاشر الجزء الثاني، أكتوبر ب.r.r. } \\
& \text { الترقيم الدولي 0826- ISSN 1110 } \\
& \text { الترقيم الدولي الموحد الإلكتروني 3178-2636 }
\end{aligned}
$$


وكتابات مبتكرة تثير الانتباه نحو السلوكيات والقضايا البيئية وقد تحقق ذلك من خلال البرنامج

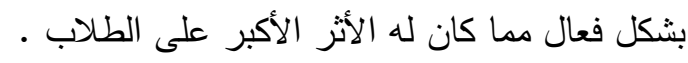
(Shirey, 2011) توصيل المعلومات أن تؤثز على فهم المشاهد وسلوكهم تجاه البيئة وكيف يمكن إستغلال القوة

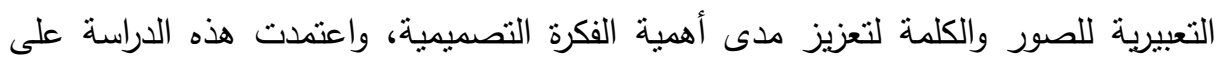

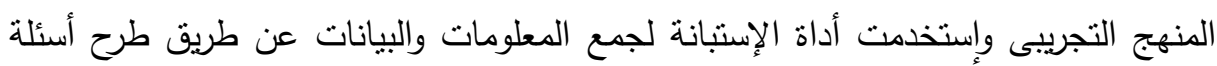
متعلقة بالقضايا البيئية، بالاضافة إلى إستخدام المحاضرات والفيديوهات التنقيفية ووسائل

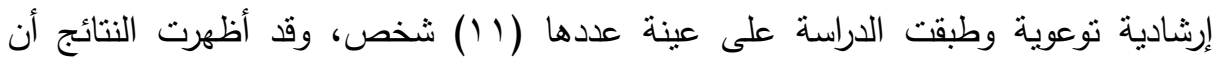
السلوك البيئى تحكمة الحياة البومية، وعادات البشر السيئة تجاة البيئة لذا فإن تحسين السلوك الييئى يعتمد على الحد من هذه العادات السيئة لذا فإن توفير الصنابير يقلل من استخدام المياة المعبئة بالقارورة واظهر الافراد رغبتهم فى تحسين سلوكهم البيئى ورغبتهم فى تنبى نقافة

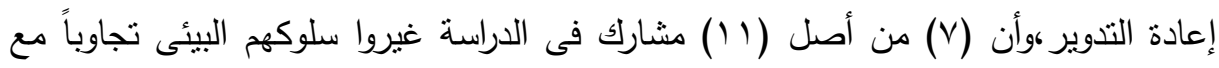
طرق العرض التفاعلية مثل الوسائل الإرشادية.

\section{الإسار النظظرى السواهما}

أولاً: التنور البيئى: التتور كمفهوم، لا يمكن أخذه بشكل مطلق، بل إنه قابل للتغير فى صيغته ومضمونه تبعاً للظروف الأجتماعية فى حقبة معينة من الزمن، فقد تتطلب حقبة تتوراً

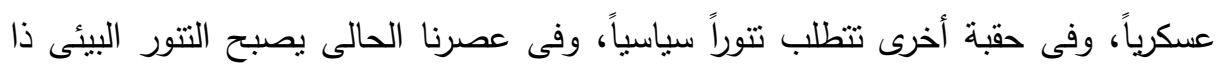

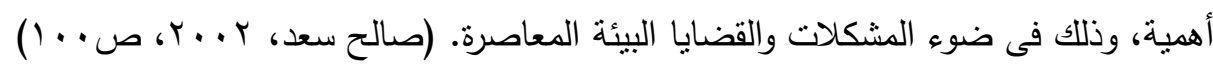

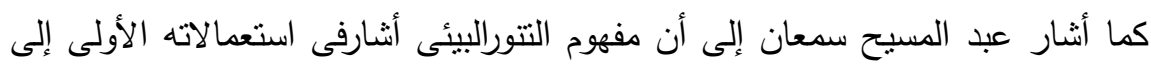

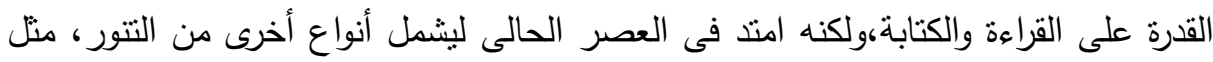
396

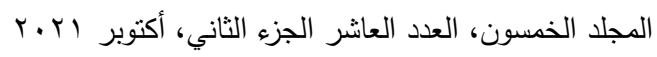

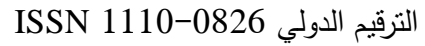

$$
\begin{aligned}
& \text { الترقيم الدولي الموحد الإلكتروني 3178-2636-26 }
\end{aligned}
$$




\section{مجلة العلوم البيئية \\ كلية الدراسات العليا والبحوث البيئية - جامعة عين شمس لبئه \\ مريم جورج عبد الثهيد وآخرون}

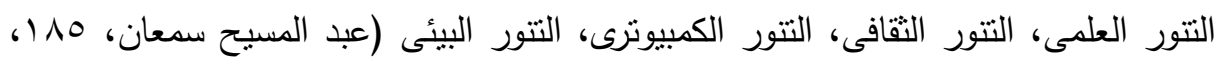
(r) r r...

كما أصبح العالم قرية صغيرة بفضل تطور وسائل الاتصال والمواصلات، وبالتالى أصبح التتور ضرورة ملحة للمواطن والمعلم والمتعلم .

وهذا يعنى أننا بحاجة إلى المواطن المتتور فى كل مكان وعمل ومهنة ليس على ولى

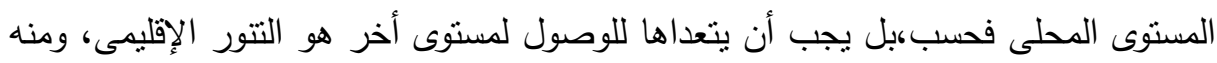
إلى مستويات التتور العالمى، وهذا يتماشىى مع طبيعة التتور البيئى (الجمعية المصرية

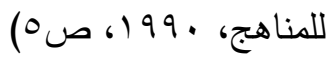

كما أن المفهوم المعاصر للتنور يتطلب من المتعلم ان بتماثبي مع طبيعة الحياة نفسها، وأن يكون لديه قدرا مناسبا من المعرفة والمهارات المتتوعة والمتعددة، ومعرفة عميقة بالاتجاهات والقيم، وان ينعكس كل ذلك على تصرفانه لتهن كمواطن.

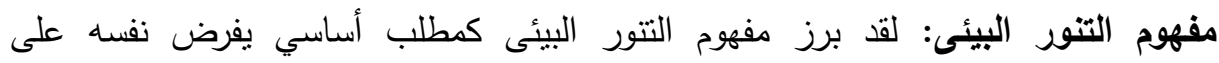

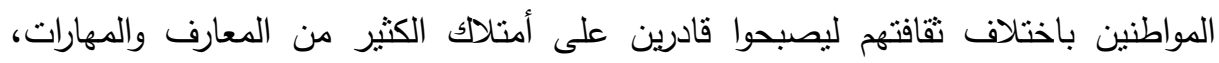

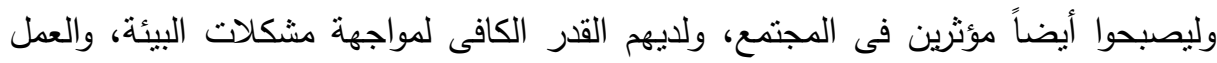

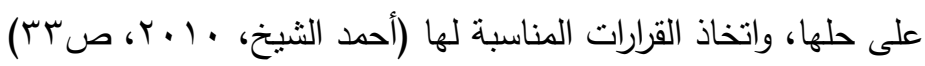

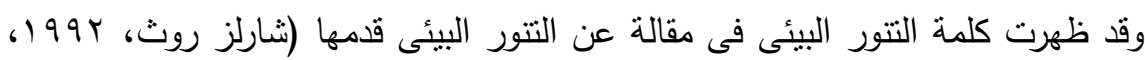

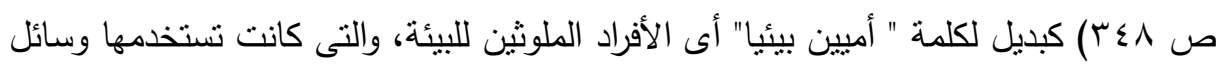

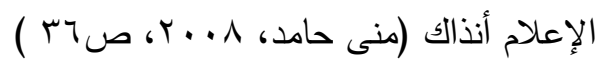

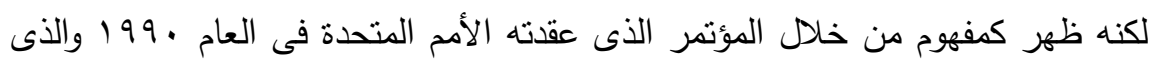

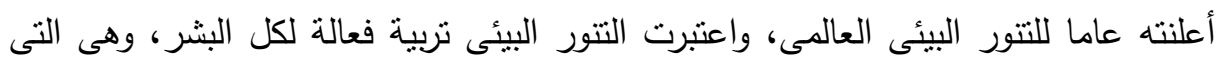

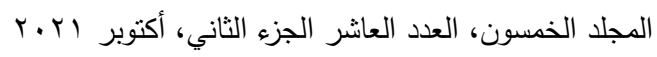

$$
\begin{aligned}
& \text { التزقيم الدولي 0826- ISSN 1110 } \\
& \text { الترقيم الدولي الموحد الإلكتروني 3178-2636-26 التربي }
\end{aligned}
$$


تمد الفرد بالمعرفة الأساسية والمهارات والدوافع لمواجهة احتياجات البيئة والمساهمة فى التتمية

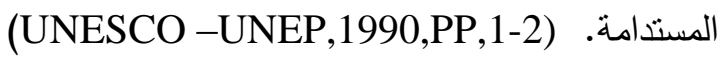

ومن مفاهيم التتور البيئى التى توصل إليها العديد من الباحثين فى مجال التربية البيئة

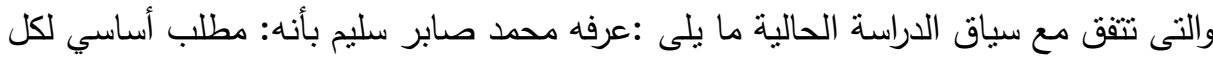
مواطن يعيش هذا العصر بكفاءة، قادرا على مواجهة تحدياته، ومتفوقا على مشاكل البيئة،

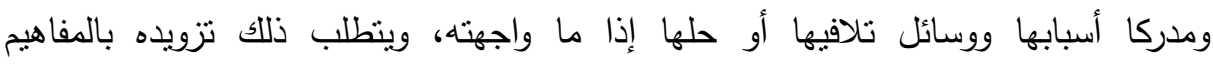

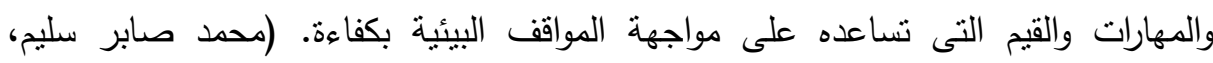
(r) 1990

وعرفه عبدالمسيح سمعان بأنه : تتمية للجوانب المعرفية والوجدانية والمهارية والسلوكية للأفراد لإدراك وفهم البيئة، والتعامل معها بشكل يحافظ على نظامها، واتخاذ مواقف إيجابية، والمشاركة فى حل مشكلاتها، والعمل على صيانتها، وذلك فى إطار تتمية تتواصل بشكل دائم

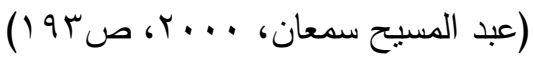
كما عرفه تتين جانج هس بأنه : ما يجب اكتسابه من خلال سلوكيات الأفراد بصفة عامة مع التحكم فى المسئوليات والأحداث البيئة ووجود استعدادات سلوكية مكتسبة يتم تقديمها من خلال أنشطة وبرامج معدة لهؤلاء الأفراد والعمل على تتميتها فى المستقبل . (SHIN JANG HSU ,2004,PP37-48) وتعددت أبعاد عناصر التنور البيئى: المعارف البيئية: تعرف بأنها المعلومات الأساسية المرتبطة بالبيئة ومكوناتها والتى تزود الفرد بخبرات متتوعة تؤدى الى فهم بيئته الإسهام فى حل قضاياها ومشكلاتها (Cattrell, 1993) 
التأثثر ويتضمن: الأتجاهات: الموقف الذى يتخذه الفرد تجاه موضوع او قضية معينة إما

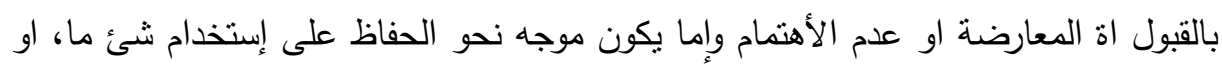
الحد من مشكلة معينة. الرغبة فى التصرف: يشير إلى استعداد الفرد والتزامة اللفظى على أساس المعتقدات او

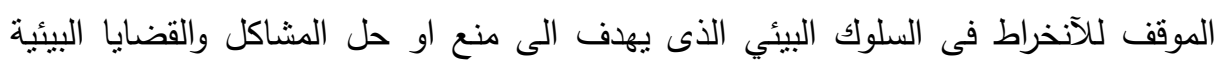
(Momroe et al: 2004) التصرف: تللك السلوكيات البيئة التى يشجع فيها الأفراد ويناشدون الأخرين للمساعدة فى منع أو حل المشكلات والقضايا البيئية ( Humgerfard, H.: 1980). السلوك المؤيد للبيئة: السلوكيات الرامية إلى تجنب الإهدار والحفاظ على الموارد والحد من التأثنير وتخفيف الأضرار البيئية وايجاد حلول وعمليات مبتكرة جديدة، وتتثمل هذة الفئة الفئة السلوكيات الأجتماعية التى تدعم وتحفز وتتجع السلوكيات المستدامة للأفراد الأخرين (Bamberg, Moser, 2007, p.17) المهارات العقلية: وتتضمن القدرة على تحليل وتوليف وتقييم المعلومات لإيجاد حلول للمشكلات البيئية على أساس الأدلة التجريبية والقيم الثخصية، والقدرة على تلى تحديد استراتيجيات العمل المناسبة، ووضع خطط العمل وتقيمها وتتفيذها. (محمد درويش المرزوقى، (Y.. T

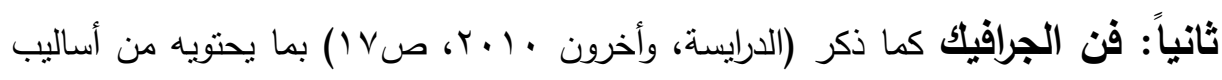

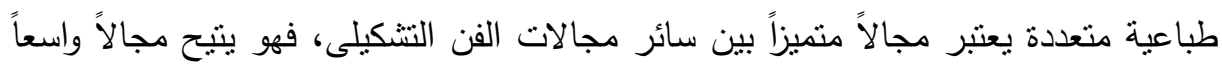

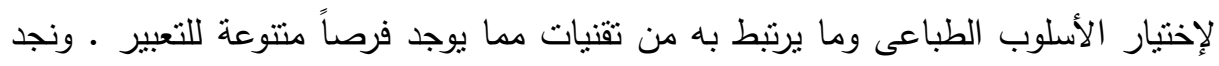

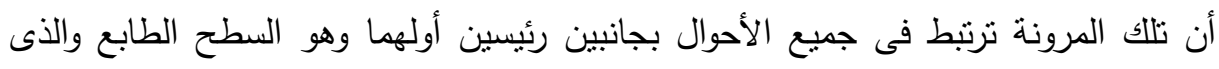

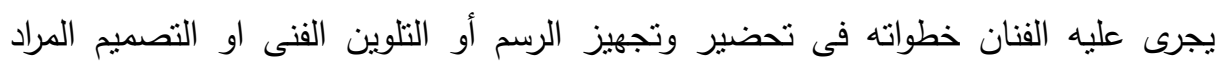

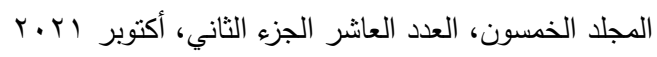

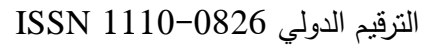

$$
\begin{aligned}
& \text { الترقيم الدولي الموحد الإلكتروني 3178-2636-26 }
\end{aligned}
$$




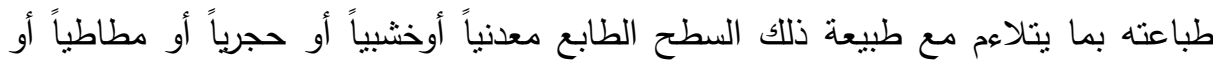

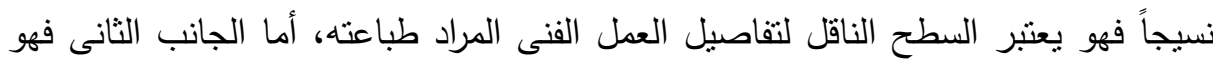

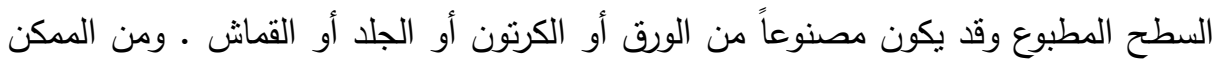

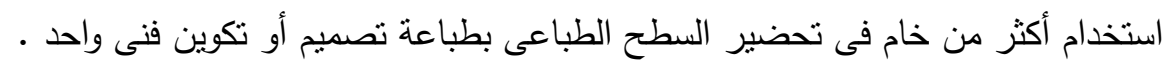
تعريف فن الجرافيك: فن الجرافيك هو مصطلح يشير إلى الرسومات والصور التي ينم التعامل معها من خلال الحاسب مثل الصور والدصلقات الإعلانية والنشرات والرسومات الترات البيانية.

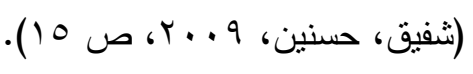

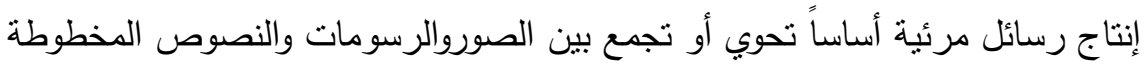

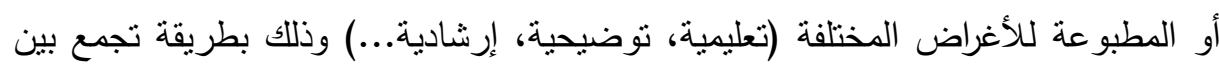

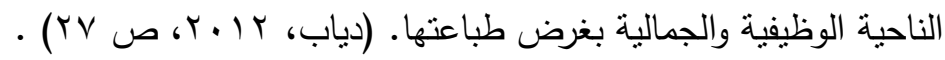

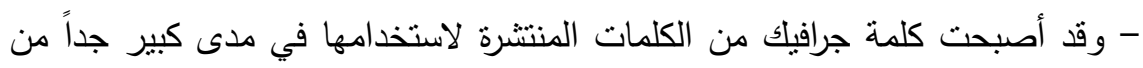
التخصصات العلمية والفنية، وقد ازداد هذا الانتشار في السنوات الماضية في مجالات أكثات أكثر

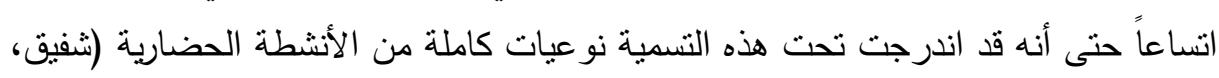

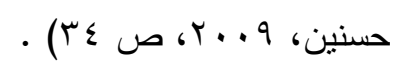

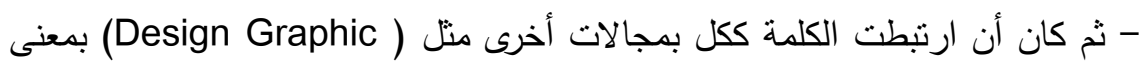

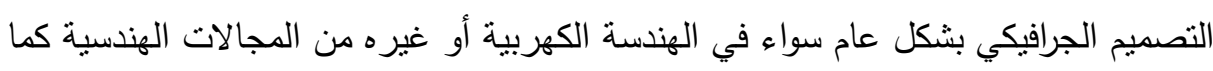

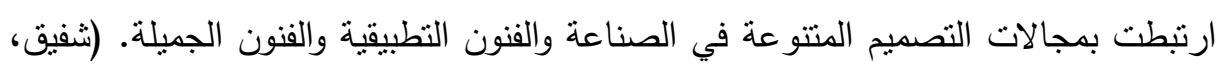

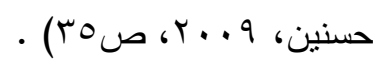
ثالثاً: الأنثطة (الوسائل الأرشادية): اتعددت مسميات وتعريفات الأنثطة الددرسية

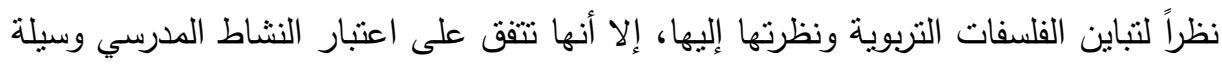

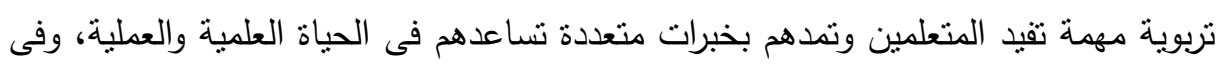
400

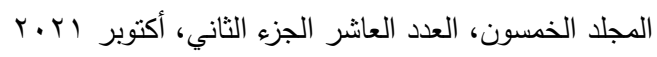

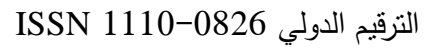

$$
\begin{aligned}
& \text { التزقيم الدولي الموحد الإلكتروني 026-3178-2636 }
\end{aligned}
$$




\section{مجلة العلوم البيئية \\ كلية الدراسات العليا والبحوث البيئية - جامعة عين شمس لهـ \\ مريم جورج عبد الثهيد وآخرون}

تحقيق التربية المنوازنة فى كافة الجوانب وذللك من خلال برامج متكاملة مع البرنامج التعليمى تخطط لها المؤسسات التربوية وتوفر لها الإمكانيات المادية والبشرية وتنشرك فيها المتعلمين

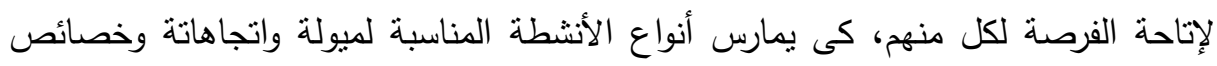

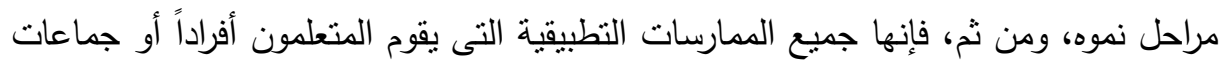

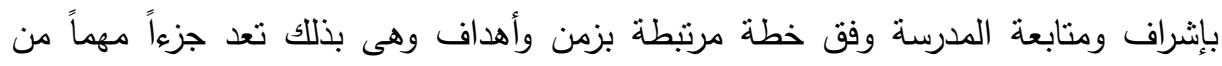

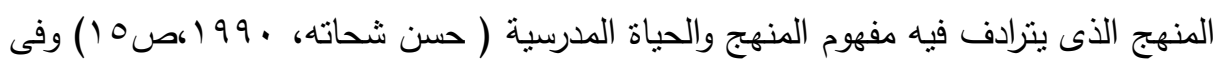
إطار كون الأنشطة تمثل العنصر الثالث من عناصر المنهج ( الأهداف - المحتوى -

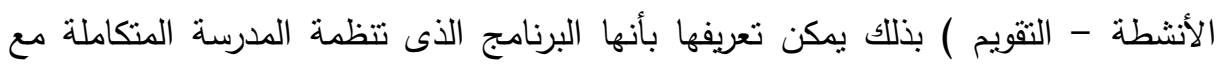

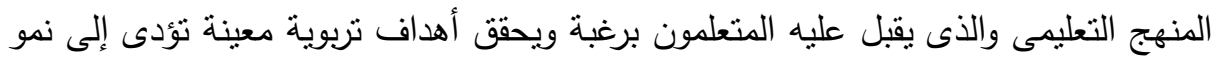

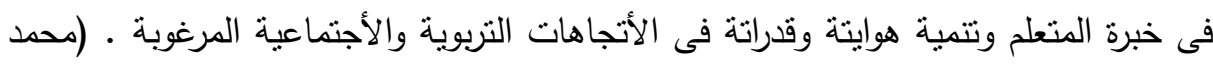
المنيف،

وتصنف الأنثطة فى مجالين واسعين هما النشاط المصاحب للمنهج ويتمثل الجانب النطبيقى للمواد الدراسية ويتفقد معها بطريقة مباشرة. النشاط الحر وهو يعالج ما قد يكون فى ولى فين

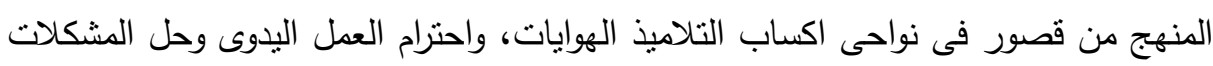
وقت الفراغ، وتوجيه السلوك، بناء الثخصية. ويتصل بالمقرارات الدراسية اتصالاً غير مباشرة

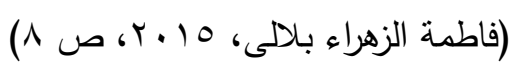
وتصنيف اللأنشطة الحرة تصنيفات كثيرة منها : أنشطة تعلمبة اذا مورست من المعلم،

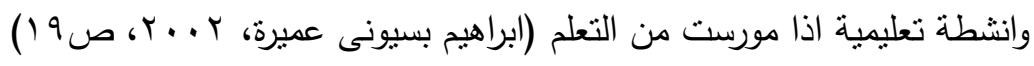

$$
\begin{aligned}
& \text { المجلد الخمسون، العدد العاشر الجزء الثاني، أكتوبر ب r.r. }
\end{aligned}
$$

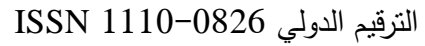

$$
\begin{aligned}
& \text { الترقيم الدولي الموحد الإلكتروني 3178-2636-26 التربي }
\end{aligned}
$$




\section{إلجراءائ المهمث}

منهج البحث: يستخدم البحث الحالى المنهج التجريبى للتعرف على اثر المتغير المستقل

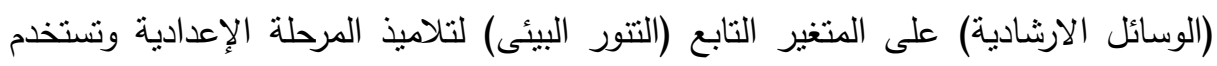

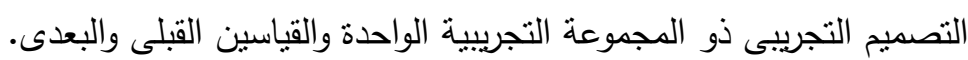

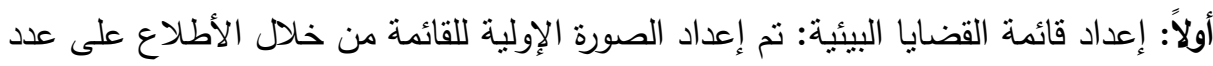

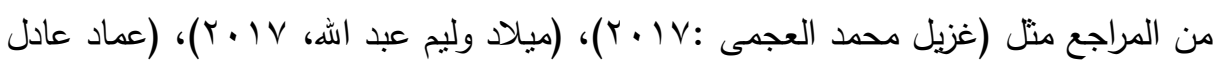

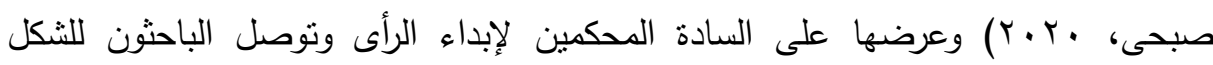

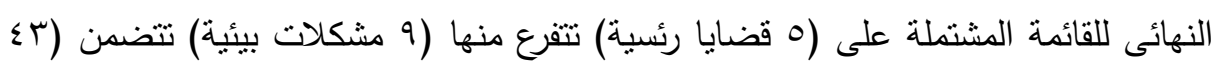

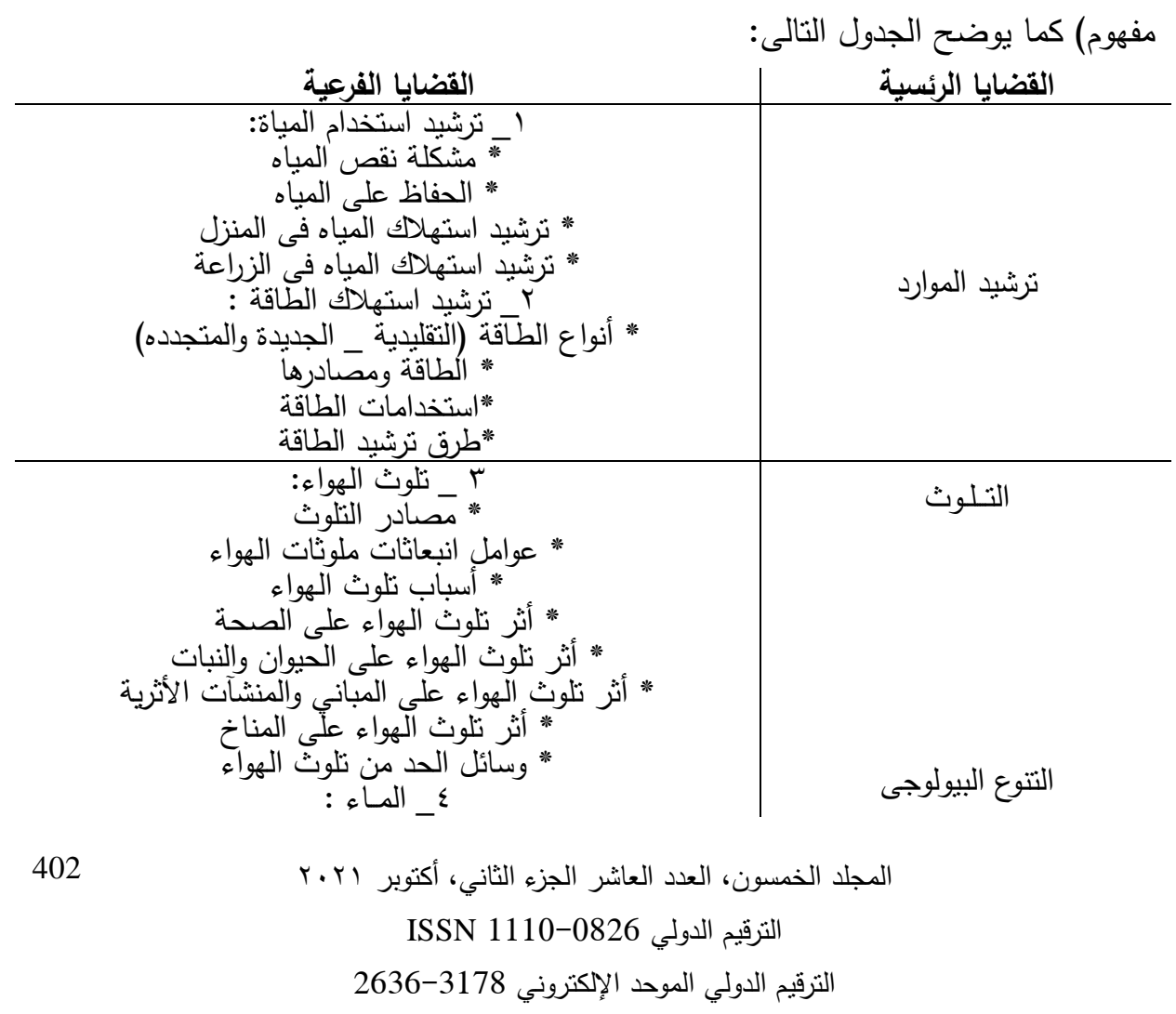




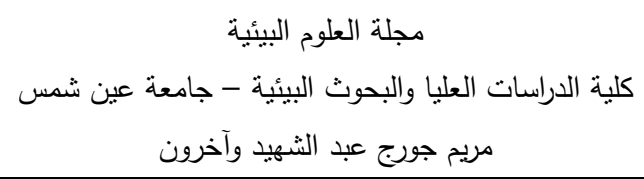

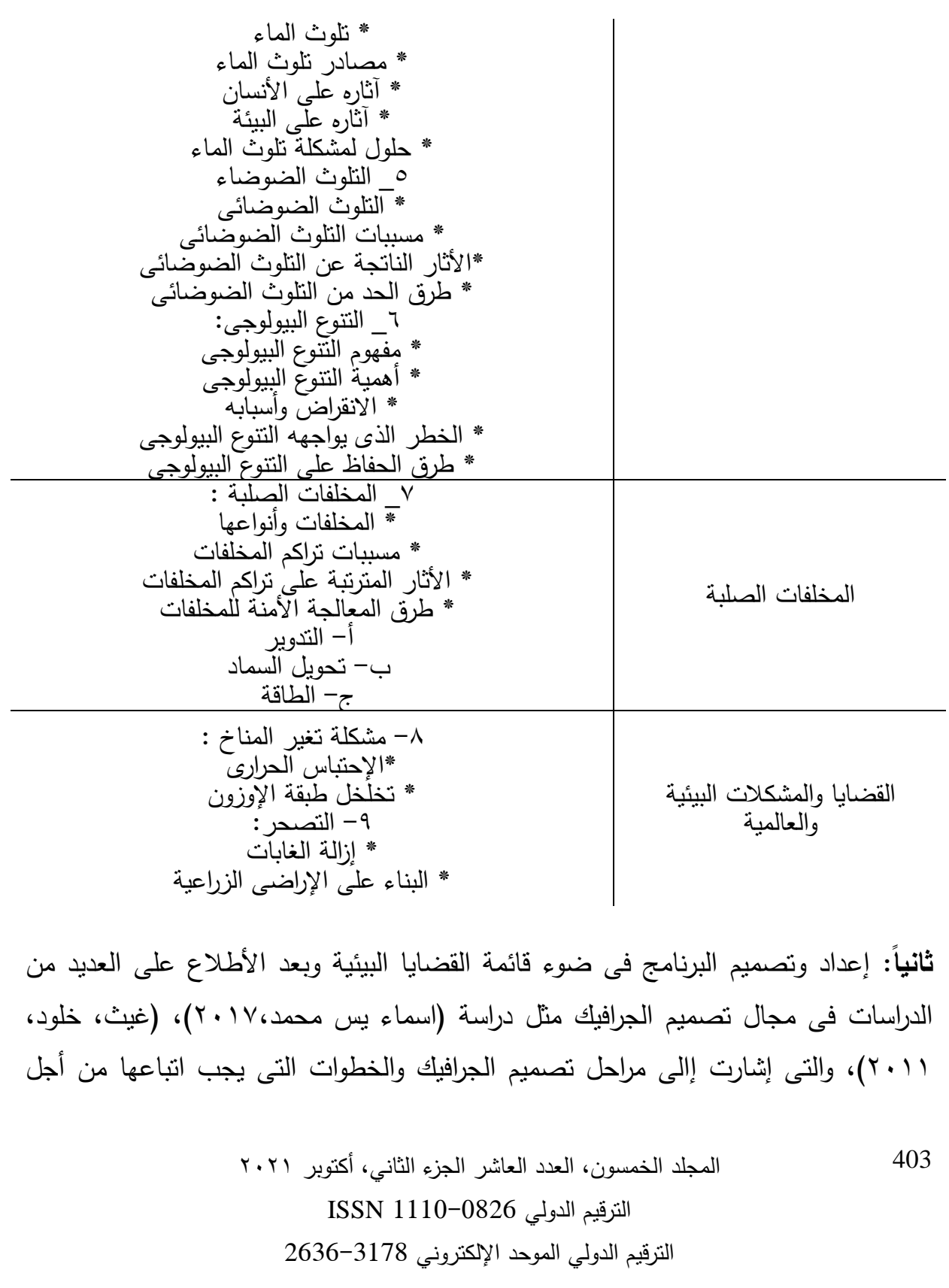




\section{مجلة العلوم البيئية \\ كلية الدراسات العليا والبحوث البيئية - جامعة عين شمس لهـ \\ مريم جورج عبد الثهيد وآخرون}

الحصول على الصورة النهائية للبرنامج والتى تثمل جميع عناصر البرنامج لتحقيق الهدف

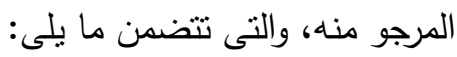
مقدمة عن البرنامج: - يقدم البرنامج المقترح مضمونه فى قالب عصري حديث والإستفادة من نطبيقات الحاسوب وامكانياته الهائلة فى العملية التعليمية وتوظيف فن الجرافيك فى إنتاج الوسائل الإرشادية لتتمية التتور البيئي لاى تلاميذ المرحلة الآعدادية.

\section{تصبد الأهداف للبرنامج المستخدم:}

1- اكتساب التلاميذ المفاهيم والمعارف البيئية ذات الصلة بالتتور البيئي والتى نساعدهم على البى فهم البيئة وبعض القضايا البيئية وأهمية البيئية.

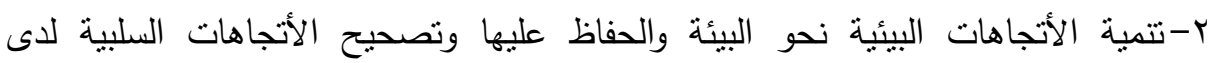
التناميذ. r-تتمية المهارات البيئية من خلد تحديد المشكلات البيئية واقتراح بعض الحلول للمشكلات البيئية.

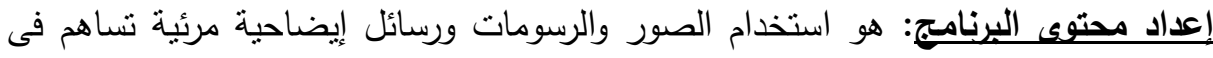

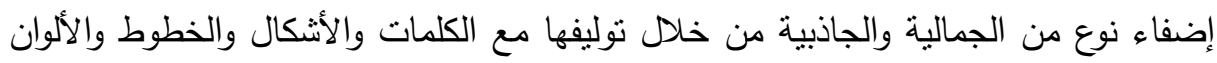
والآنطباعات التصويرية والمكتوبة لإعطاء التصميم او الوسيلة الأرشادية شكلها النهائى وكأنها وحدة واحدة او كيان واحد) ان الأخراج والتصميم عمل ابتكارى يتمتع بشقين رئيسينتين: KOTLER.P يتجسد على ارض الواقع من خلال مزج ابتكارى بين الواقع والخيال لينتج عنهما واقع ابداعى الهى

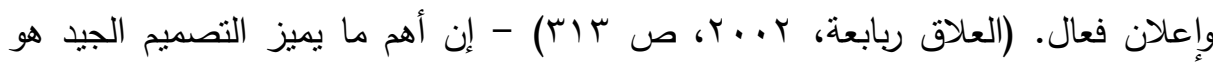

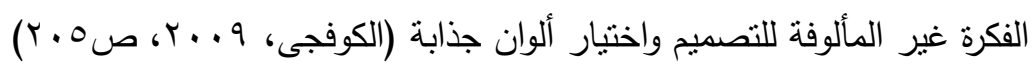

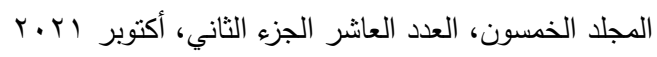

$$
\begin{aligned}
& \text { الترقيم الدولي 0826- ISSN 1110 } \\
& \text { التزقيم الدولي الموحد الإلكتروني 3178-2636-26 }
\end{aligned}
$$


يقصد بالمحتوى المادة العلمية بكل ما تشملة من معلومات وحقائق ومفاهيم وقوانين ونظريات ومهارات واتجاهات وقيم فى ضوء ما تم التوصل إلية من الأهداف الأجرائية (فارعة معليم

حسن محمد، • (1) وقد توافر الثروط التالية فى اختيار البرنامج: • ان يتضمن محتوى البرنامج قائمة الموضوعات والمشكلات البيئية التى ينبغى تضمينها فى لئ محتوى الوسائل الأششادية. • أن يكون متسقاً مع الأهداف السلوكية للبرنامج. • • • • • • • أن تكون صباغة المحتوى سلسة ومنطقية. • ان يكون المحتوى انعكاساً فعلياً لاحتياجات التلاميذ فى تتمية بعضية بعض عناصر النتور البيئى لديهم.

الأدوات المستخدمة لتنفيذ البرنامجج:

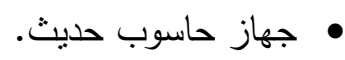

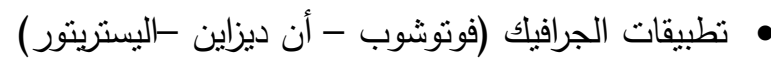
Net work • تطبيقات مايكروسوفت أوفس.

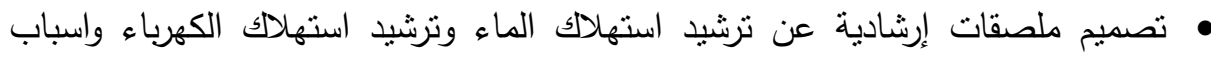
واخطار التلوث الضوضائى. تصميم استيكر يتتاول بعض القضايا البيئية منل إعادة التدوير وترشيد الكهرباء والمحافظة

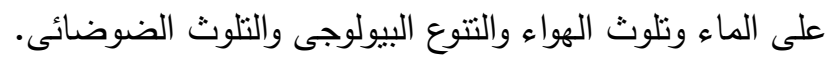


تصميم برشور عن تلوث الهواء ومصادر التلوث وتاثير تلوث الهواء على صحة الانسان

$$
\text { وبعض الحلول. }
$$

• تصميم مجلات عن أهمية المياه وأهمية المحافظة على التتوع البيولوجى.

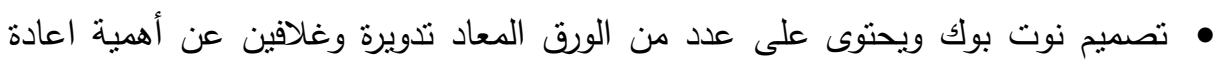

$$
\text { التدوير }
$$

تصميم نتيجة مكتب وتحتوى على T ا تصميم لتلوث الهواء واهمية الماء وترشيدها وترشيد

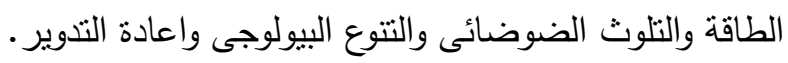
• • تصميم استيكر سي دى عن اخطار الاحتباس الحرارى.

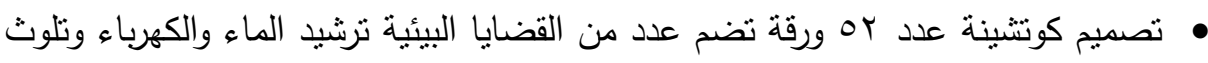
الماء والهواء والتلوث الضوضائى والتنوع البيولوجى واهمية اعادة التدوير والاحتباس الهن الحرارى والتصحر وازالة الغابات.

• تصميم العاب بيئية عن نرشيد الكهباء والتتوع البيولوجى واعادة التدوير والمحافظة على وابى

$$
\text { الماء من التلوث. }
$$

• تصميم والطباعة على مج عن تلوث الماء وطرق الترشيد وطرق ترشيد الكهباء وأهمية

$$
\text { اعادة التدوير • }
$$

• تصميم وطباعة على حافظة ورق للمحافظة على الماء من التلوث.

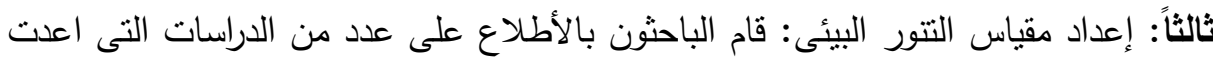

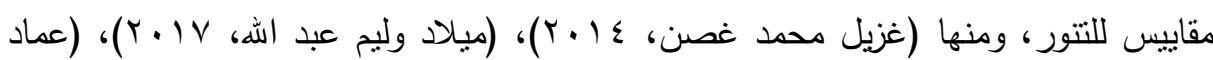

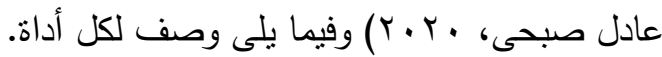

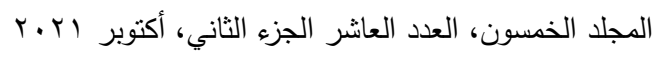

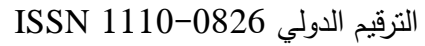

$$
\begin{aligned}
& \text { الترقيم الدولي الموحد الإلكتروني 3178-2636-26 }
\end{aligned}
$$




\section{اختبار المعارف البيئة:}

1- تحديد الهلف من الأختبار : التعرف على المعارف البيئية موضوع البحث لدى تلاميذ

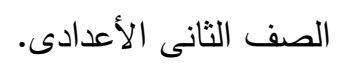

r- تحديد القضايا التى يتضمنها الأختبار : ثم تحديد قضايا البيئة فى ضوء ما أنتهت إلية قائمة قضايا التتور البيئي فى صورتها النهائية النيان

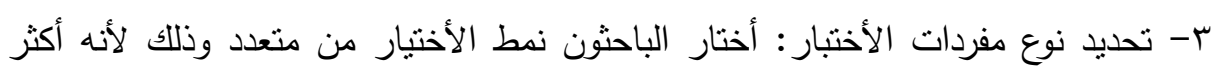

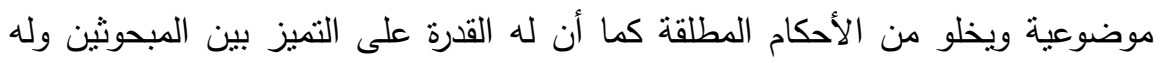

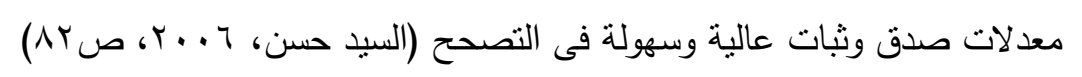

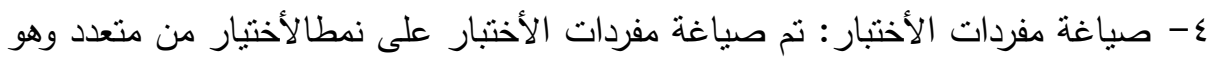

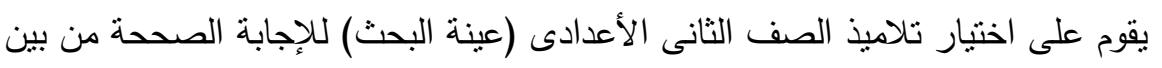

$$
\text { عدة إجابات. }
$$

0- الصورة المبئية للأختبار : نم بناء الأختبار مع مراعاة الأسس التى سبق الأشارة إليها

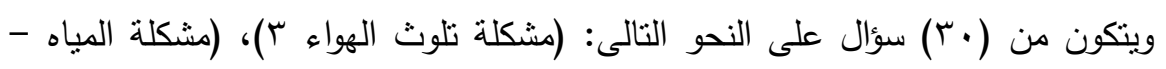

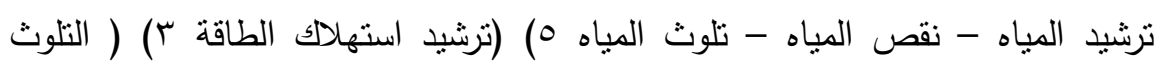

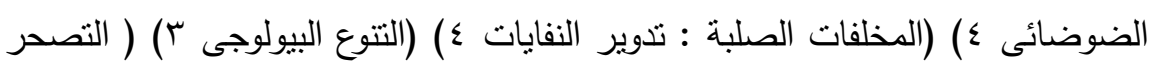

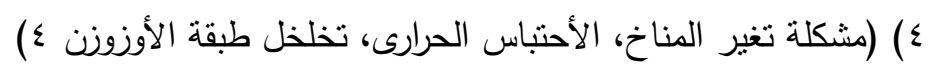

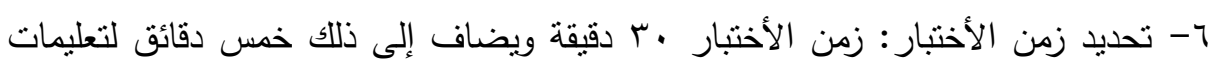

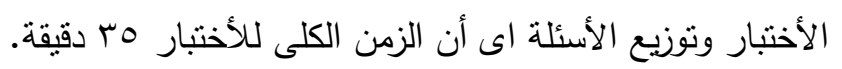

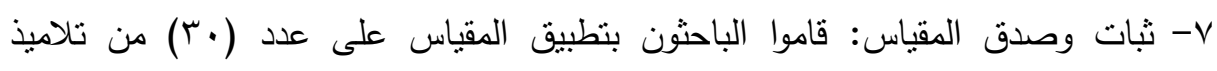
الصف الثانى الإعدادى وتتوافر فيهم شروط الأختبار وتم إعادة التطبيق بعد خمسة عشر الثر

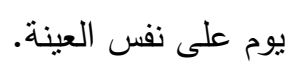

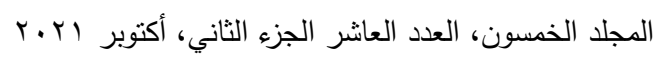

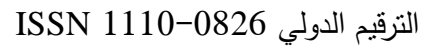

$$
\begin{aligned}
& \text { الترقيم الدولي الموحد الإلكتروني 3178-2636-26 }
\end{aligned}
$$


ᄉ- ثبات الأختبار : اى أن يعطى نفس النتائج إذا قاس نفس الثـئ مرات متعددة، وقد استخدم الباحثون (ALPHA Cronbachs) معامل ألفا كرونباخ لقياس ثبات عبارات اختبار المعلومات البيئية والجدول التالى ( () يوضح ذلك. جدول (1): ثبات عبارات اختبار المعلومات البيئية

\begin{tabular}{|c|c|c|}
\hline قيمة ألفا & عدد العبارات & أبعاد الاختبار \\
\hline$\cdot, 777$ & $r$ & مشكلة تلوث الهواء \\
\hline$\cdot, 77 \varepsilon$ & 0 & مشكلة المياه \\
\hline., $0 \wedge \mathrm{V}$ & $r$ & ترشيد استهلاك الطاقة \\
\hline$\cdot, \pi 7 \pi$ & $\varepsilon$ & التلوث الضوضائي \\
\hline$\cdot, 7 r V$ & $\varepsilon$ & المخلفات الصلبة (تدوير النفايات) \\
\hline$\cdot, 7 \leqslant$. & $r$ & التتوع البيولوجى \\
\hline., 770 & $\varepsilon$ & التصحر \\
\hline$\cdot, \mathrm{VTY}$ & $\varepsilon$ & مشكلة تغير المناخ \\
\hline$\cdot, 109$ & $r$. & الدرجة الكلية اختبار المعلومات البيئية \\
\hline
\end{tabular}

تبين من نتائج معادلة ألفا كرونباخ (Alpha Cronbach) لتبات اختبار المعلومات

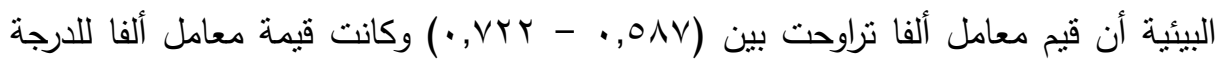

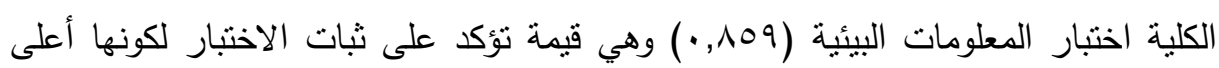

$$
\text { من (0) }
$$

9- صدق الاختبار: نم النأكد من صدق المحكمين وقد وجد أتفاق كبير فى أراء المحكمين

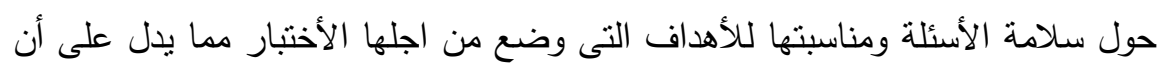
الأختبار يحظى بمعدل صدق منطقى. 
مجلة العلوم البيئية

كلية الدراسات العليا والبحوث البيئية - جامعة عين شمس البئة

مريم جورج عبد الثهيد وآخرون

جلول (Y): صدق أبعاد اختبار المعلومات البيئية

\begin{tabular}{|c|c|c|}
\hline الدلالة المعنوية & معامل ارتباط بيرسون & أبعاد المقياس \\
\hline,$\ldots$, & $\cdot, \vee, \cdot$ & مشكلة تلوث الهواء \\
\hline$\cdot, \ldots 1$ & $\cdot, \vee \vee 99$ & مشكلة المياه \\
\hline$\cdot, \ldots$, & $\cdot, 7 \vee 0$ & ترشيد استهلالك الطاقة \\
\hline$\cdot, \ldots 1$ & $\cdot, \mathrm{\vee} \wedge \wedge$ & التلوث الضوضائي \\
\hline$\cdot, \ldots 1$ & $\cdot, \vee \vee \neg$ & المخلفات الصلبة (تدوير النفايات) \\
\hline$\cdot, \ldots 1$ &., 70. & التتوع البيولوجى \\
\hline$\cdot, \ldots 1$ & $\cdot, \vee 09$ & التصحر \\
\hline.,$\ldots 1$ & $\cdot, \mathrm{VT}$. & مشكلة تغير المناخ \\
\hline
\end{tabular}

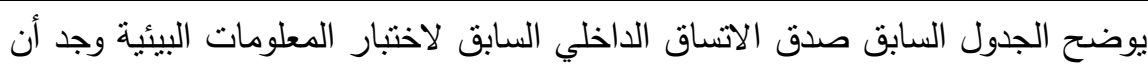

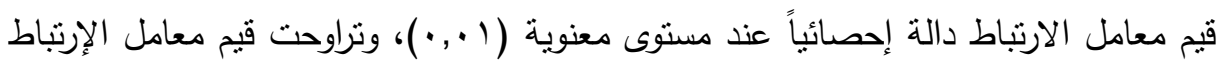

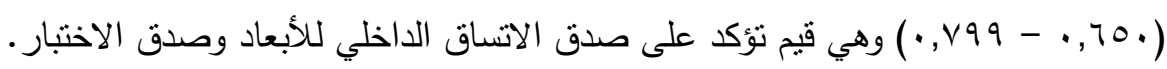

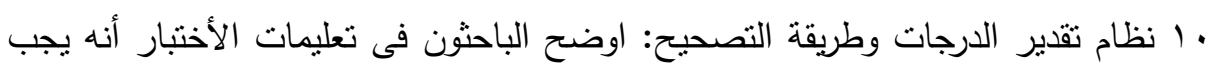

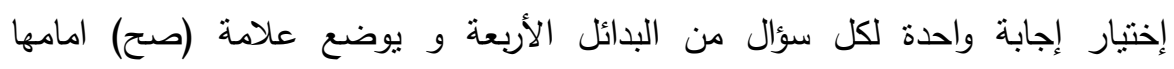
وخصص الباحثون درجة لكل إجابة صحيحة وصفر إذا كانت الأجابة خاطئة وكانت الت الته

$$
\text { العظمى ( • (ب) والصغرى (صفر) ). }
$$

1)- الصورة النهائية للإختبار : بعد الإجراءات السابقة أصبح الأختبار فى صورته النهائية

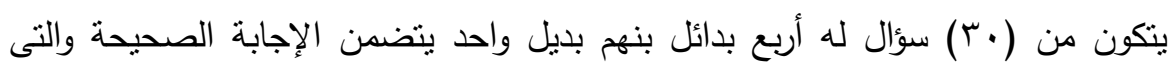

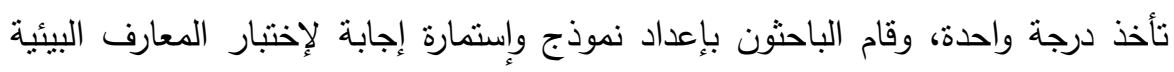

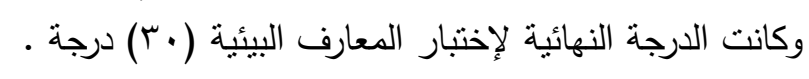

مقياس الاتجاهات: بعد الرجوع إلى عدد من الدراسات السابقة منها دراسة (نصر محمد على

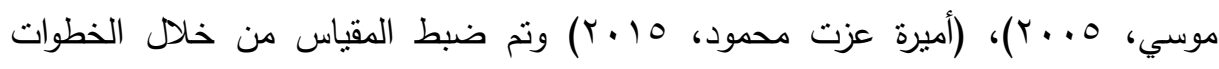
التالية:

$$
\begin{aligned}
& \text { المجلد الخمسون، العدد العاشر الجزء الثاني، أكتوبر ب r.r. }
\end{aligned}
$$

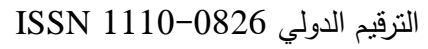

$$
\begin{aligned}
& \text { الترقيم الدولي الموحد الإلكتروني 3178-2636 }
\end{aligned}
$$


1-تحديد الهدف من المقياس: يهدف المقياس إلى قياس الأتجاهات البيئية لاى تلاميذ الصف

الثانى الإعدادى، كمقياس قبلى، ومقياس بعدى لقياس مدى الأختلاف بين اتجاهات (عينة البحث) بعد تطبيق البرنامج.

r-تحديد القضايا التى يتضمنها المقياس: نم تحديد القضايا البيئية فى ضوء مانجاء أنتهت إلية قائمة قضايا التتور البيئي فى صورتها النهائية. ب-صياغة مفردات المقياس: تم صباغة المقياس على أساس المواقف السلوكية وقد تضمن فئن

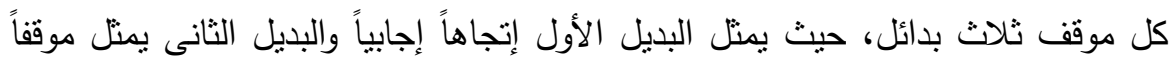

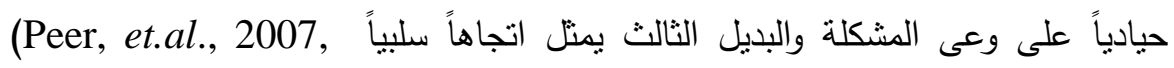
p.423-431)

ع - إعداد الصورة المبئية للمقياس: بعد الأنتهاء من إعداد المقياس تم عرضة على محكمين

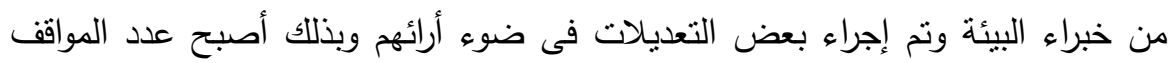

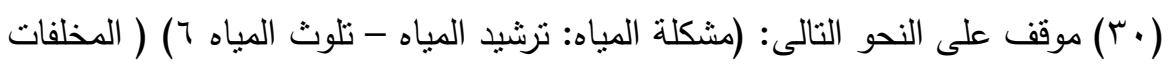

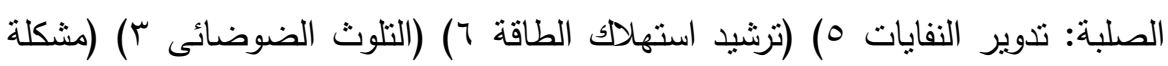

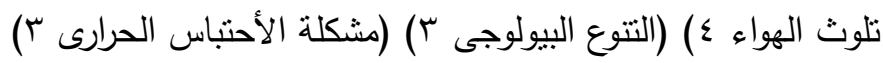

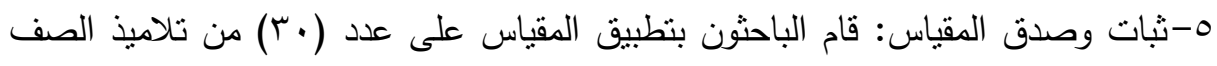

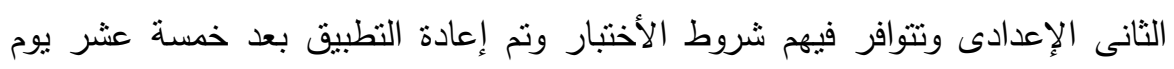
على نفس العينة. ج-ثبات المقياس: يقدر الثبات بتحديد نسبة التغير المنتظم فى المقياس من خلال حساب مدى الأرتباط بين درجات المقياس التى يحصل عليها عبر النطبقات المختلفة للمقياس،

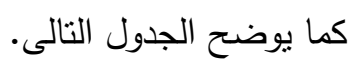

$$
\begin{aligned}
& \text { المجلد الخمسون، العدد العاشر الجزء الثاني، أكتوبر ب r.r. }
\end{aligned}
$$

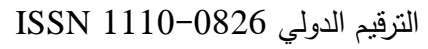

$$
\begin{aligned}
& \text { الترقيم الدولي الموحد الإلكتروني 3178-2636-26 التربي }
\end{aligned}
$$


مجلة العلوم البيئية

كلية الدراسات العليا والبحوث البيئية - جامعة عين شمس البئة

مريم جورج عبد الثهيد وآخرون

جدول (ץ): ثبات عبارات مقياس الاتجاهات البيئية

\begin{tabular}{|c|c|c|}
\hline قيمة ألفا & عدد العبارات & أبعاد المقياس \\
\hline$\cdot, \Lambda I V$ & 7 & مشكلة المياه \\
\hline$\cdot, \vee \vee 1)$ & 0 & المخلفات الصلبة (تدوير النفايات) \\
\hline$\cdot, V \leq \varepsilon$ & 7 & ترشيد استهلالك الطاقة \\
\hline$\cdot, T / Y$ & $r$ & التلوث الضوضائى \\
\hline$\cdot, V Y \leq$ & $\varepsilon$ & مشكلة تلوث الهواء \\
\hline$\cdot, \vee \vee 97$ & $r$ & التتوع البيولوجى \\
\hline$\cdot, \lambda \mid Y$ & $r$ & مشكلة الاحتباس الحرارى \\
\hline$\cdot, 97$. & $r$. & الدرجة الكلية لمقياس الاتجاهات البيئية \\
\hline
\end{tabular}

تبين من نتائج معادلة ألفا كرونباخ (Alpha Cronbach) لثبات مقياس الاتجاهات

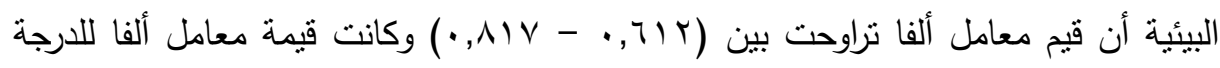

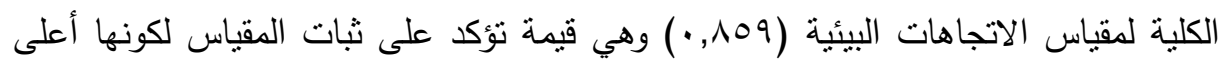

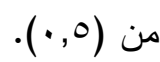

V- صدق المقياس: قام الباحث بإجراء صدق المحكمين حيث وجد أتفاق كبير فى أرائهم حول سلامة

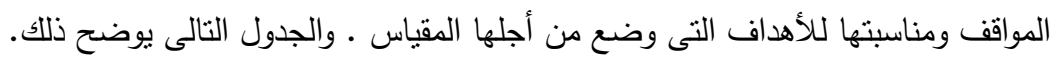

$$
\text { جدول (؛): صدق أبعاد مقياس الاتجاهات البيئية }
$$

\begin{tabular}{|c|c|c|}
\hline الدلالة المعنوية & معامل ارتباط بيرسون & أبعاد المقياس \\
\hline$\cdot, \cdots 1$ & $\cdot, 9 \leq \varepsilon$ & مشكلة المباه \\
\hline$\cdot, \cdots 1$ & $\cdot, 9.9$ & المخلفات الصلبة (تدوير النفايات) \\
\hline$\cdot, \cdots 1$ & $\cdot 947$ & ترشيد استهلالك الطاقة \\
\hline$\cdot, \cdots 1$ & $\cdot, \wedge \vee q$ & التلوث الضوضائيى \\
\hline$\cdot, \cdots 1$ & $\cdot 949$ & مشكلة تلوث الهواء \\
\hline$\cdot, \cdots 1$ & $\cdot, 9.0$ & التتوع البيولوجى \\
\hline$\cdot, \cdots 1$ & $\cdot, 91 \varepsilon$ & مشكلة الاحتباس الحرارى \\
\hline
\end{tabular}

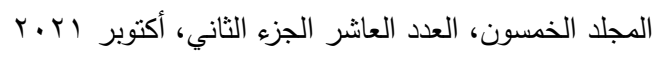

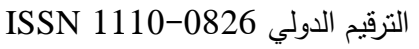

$$
\begin{aligned}
& \text { الترقيم الدولي الموحد الإلكتروني 3178-2636-26 }
\end{aligned}
$$


يوضح الجدول السابق صدق الاتساق الداخلي السابق لمقياس الاتجاهات البيئية وجد أن

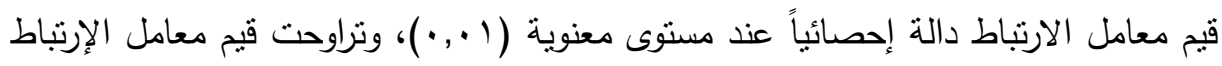

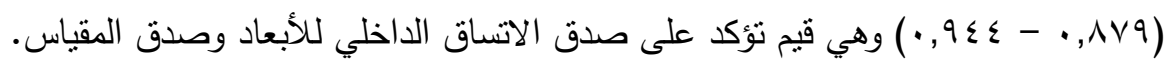

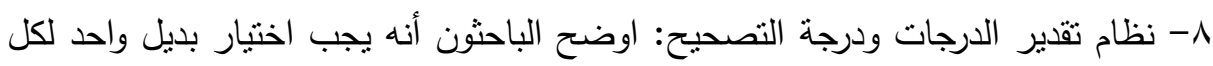

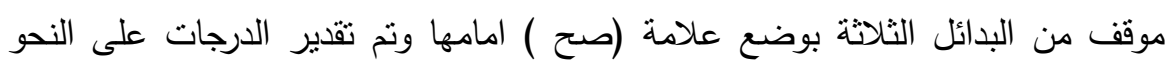

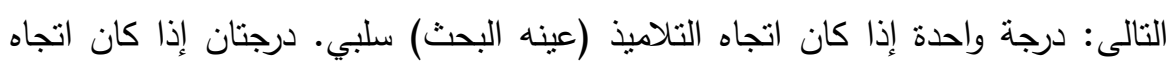

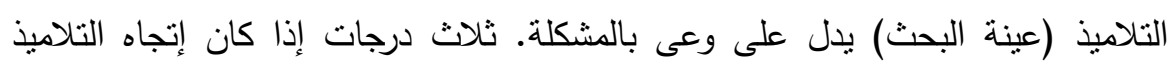

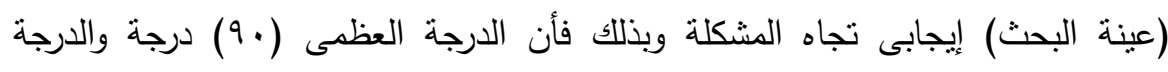

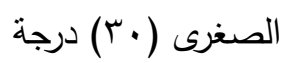

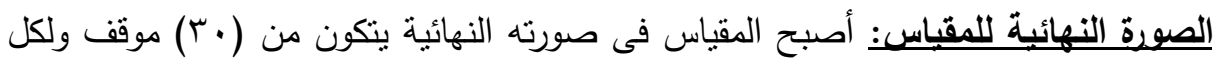

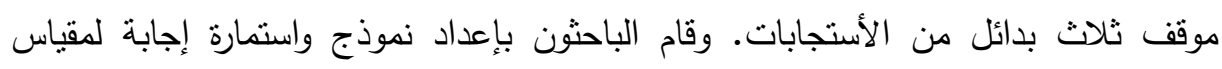

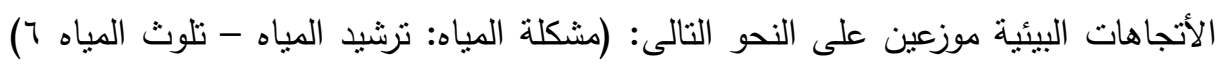

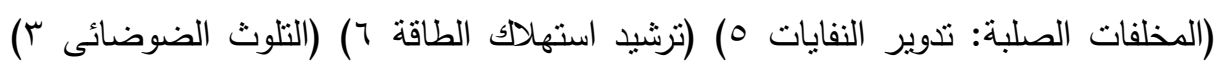

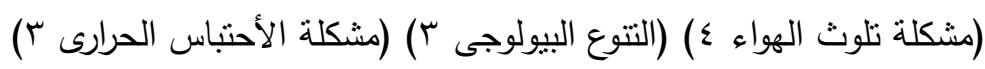
مقياس المهارات البيئية: الأساس المرجعى للمقياس: تصنيف مهارات إقتراح الحلول التى حددها كل من ستامب،

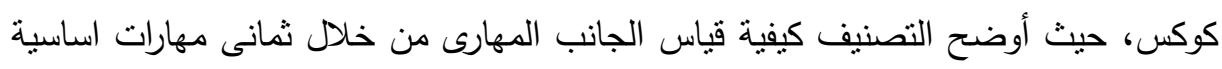

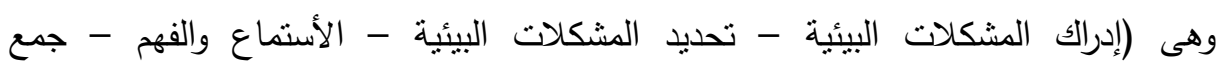

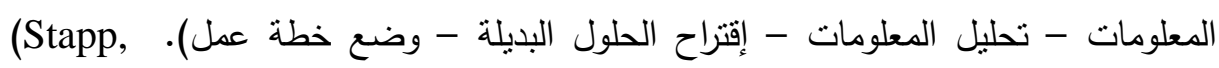

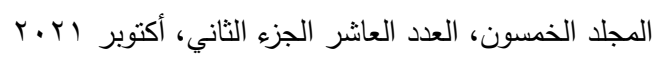

$$
\begin{aligned}
& \text { الترقيم الدولي 0826- ISSN 1110 } \\
& \text { الترقيم الدولي الموحد الإكتروني 3178-2636 }
\end{aligned}
$$




$$
\begin{aligned}
& \text { مجلة العلوم البيئية } \\
& \text { كلية الدراسات العليا والبحوث البيئية - جامعة عين شمس لئة } \\
& \text { مريم جورج عبد الثهيد وآخرون }
\end{aligned}
$$

الهدف من البحث: يهدف هذا المقياس إلى قياس مدى نوافر المهارات البيئية لدى عينة البحث.

تحدبد القضايا التى بتضمنها المقياس: نم تحديد القضايا البيئية فى ضوء ما انتهت إلية قائمة قضايا التنور البيئي فى صورتها النهائية وقد تم وضع مفردات المقياس وفقاً لمحورين

$$
\text { المئيسين هما: المحور الأول: مهارة تحديد المشكلات البيئية }
$$

تحدبد نوع مفردات المقياس: صمم الباحثون مقياس المهارات البيئية بعد مراجعة العديد من

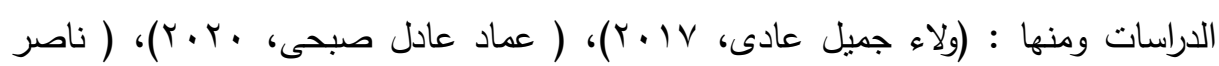
العبري، 17 (ب)

الصورة المبئية للمقياس: بعد الإنتهاء من إعداد المقياس قام الباحث بعرضة على السادة

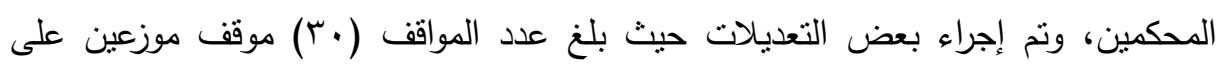

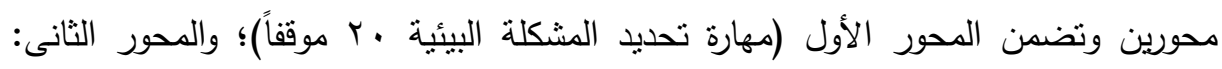
مهارة اقتراح الحلول (· ( ) مواقف. تحدب زمن المقياس: تبين من نتيجة التجريب الأستطلاعى ان الزمن المناسب للمقياس (ب0) دقيقة تشمل توزيع المقياس على المبحوثين. ثيات وصدق المقياس: قاموا الباحثون بتطبيق المقياس على عدد (·r) من تلاميذ الصف

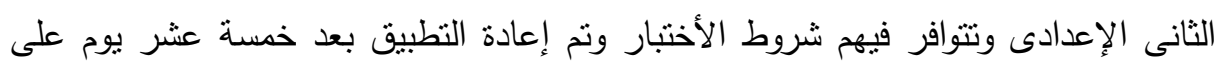
نفس العينة. ثبات المقياس: تبين من نتائج معادلة ألفا كرونباخ (Alpha Cronbach) لثبات مقياس

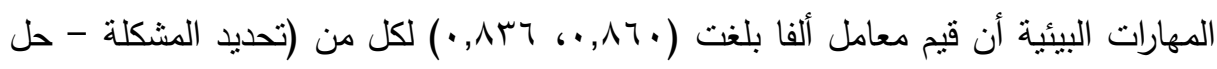

$$
\begin{aligned}
& \text { المجلد الخمسون، العدد العاشر الجزء الثاني، أكتوبر ب r.r. } \\
& \text { التزقيم الدولي 0826- ISSN 1110 } \\
& \text { الترقيم الدولي الموحد الإلكتروني 3178-2636-26 التربي }
\end{aligned}
$$


المشكلة) على التوالي، وكانت قيمة معامل ألفا للارجة الكلية لمقياس المهارات البيئية

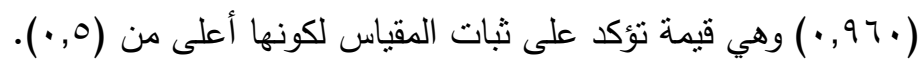

جدول (•): ثبات عبارات مقياس المهارات البيئية

\begin{tabular}{|c|c|c|}
\hline قيمة ألفا & عدد العبارات & أبعاد المقياس \\
\hline.,$\wedge \uparrow$. & r. & تحديد المشكلة \\
\hline 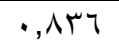 & 1. & حل الششكلة \\
\hline., 97. & $r$. & الدرجة الكلية لمقياس المهارات البيئية \\
\hline
\end{tabular}

صدق المقياس: يوضح الجدول التالى صدق الاتساق الداخلي السابق لمقياس المهارات البيئية

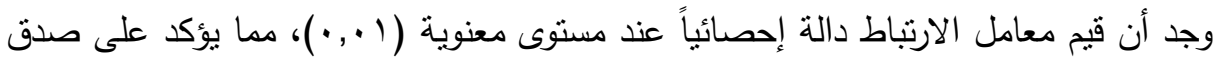

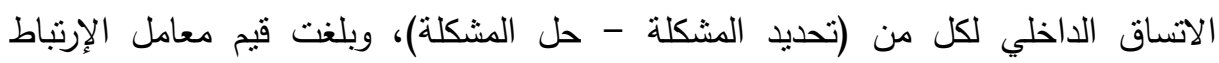

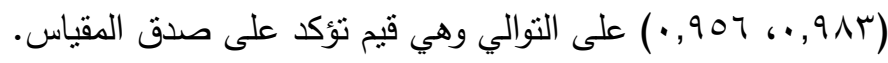
جدول (†): صدق أبعاد مقياس المهارات البيئية

\begin{tabular}{|c|c|c|}
\hline الدلالة المغنوية & معامل ارتباط بيرسون & أبعاد المقياس \\
\hline$\cdot, \ldots 1$ & $\cdot, 9 \wedge r$ & تحديد المشكلة \\
\hline.,$\ldots 1$ &., 907 & حل المشكلة \\
\hline
\end{tabular}

تقبير الارجات وطريقة التصحبح: نم تقدير درجات مقياس المهارات البيئية وفقاً للأتى: المحور الأول: أثتنمل على (·r) مفردة ثم حساب درجة واحدة لكل إجابة صحيحة، صفر لكل إجابة خاطئة (الدرجة النهائية لهذا المحور (· (†) درجة والصغرى (صفر ) ).

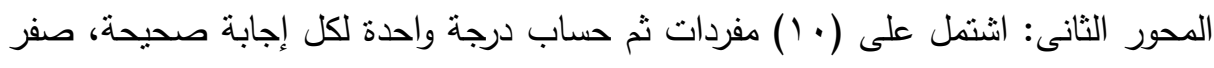
لكل إجابة خاطئة والدرجة النهائية لهذا المحور ( • (1) درجات والصغرى (صفر ). الصورة النهائبة للمقياس: بعد قيام الباحثون بالإجراءات السابقة اصبح المقياس فى صورته

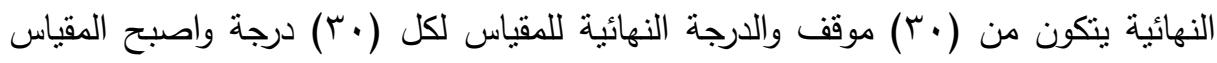
جاهز للنطبيق، وتم إعداد نموذج واستمارة إجابة لمقياس المهارات البيئية.

$$
\begin{aligned}
& \text { المجلد الخمسون، العدد العاشر الجزء الثاني، أكتوبر ب r.r. } \\
& \text { التزقيم الدولي 0826- ISSN 1110 } \\
& \text { الترقيم الدولي الموحد الإلكتروني 3178-2636-26 }
\end{aligned}
$$


رابعاً: تحديد واختيار عينة البحث: نم التطبيق على مجموعة البحث من تلاميذ الصف الثانى الأعدادى بمدرسة سويت هوم الإعدادية التابعة لإدارة شبرا التعليمية ـ وعددهم (•r). خامساً: إجراء تطبيق البرنامج وأدوات البحث: الهُف من البرنامج: التعرف على مدى فاعلية (الوسائل الإرشادية، كمتغير مستقل) على الهى

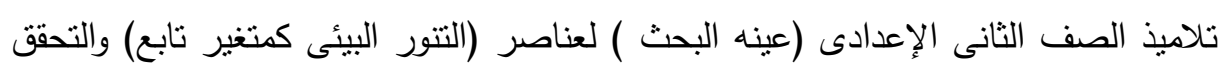
من فروض البحث.

تحديد التصميم التجريبى: نم استخدام المنهج التجريبى للتصميم التجريبي للمجموعة التجريبية الواحدة وإستخدام التطبيق القبلى والبعدى. • التطبيق القبلى لأدوات البرنامج التجريبى: قام الباحثون بالتطبيق القبلى لأدوات التقويم (اختبار المعلومات البيئية - مقياس الأتجاهات البيئية - مقياس المهارات البيئية) على بلى لإنى

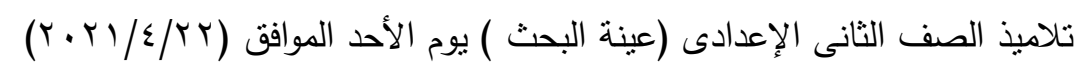

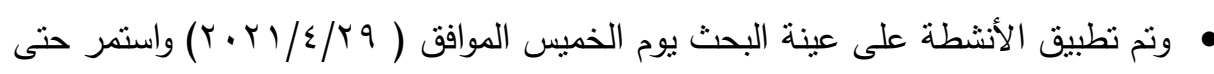
$(r \cdot r) / 0 / 0)$ • ثم تم التطبيق البعدى للمقياس ( اختبار المعلومات البيئية - مقياس الأتجاهات البيئية -

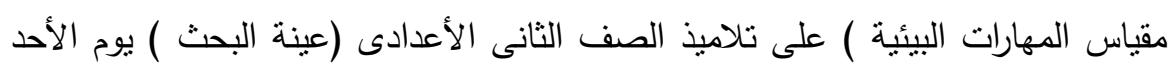

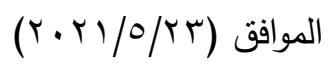

التصحيح ورصد النتائج: بعد التطبيق للمقياس قبلياً وبعدياً، قام الباحثون بتصحيح

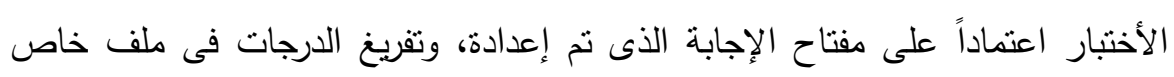
وإعدادة للمعالجة الإحصائية.

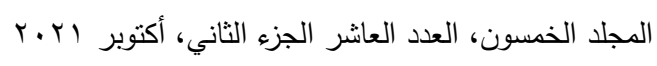

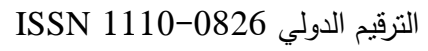

$$
\begin{aligned}
& \text { الترقيم الدولي الموحد الإلكتروني 3178-2636 }
\end{aligned}
$$


خامساً: البرنامج الأحصائى لبيانات البحث: نم تفريغ البيانات عن طريق البرنامج

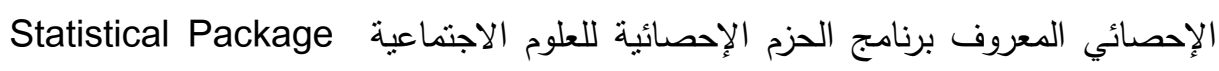
For Social Sciences الحزم الإحصائية SPS V. 25 وتعد هذه الخطوة - خطوة تمهيدية لتبويب البيانات وتحليلها إحصائيًا، ومن خلاله نم استخدام الاختبارات التالية: • اختبار معامل ألفا كرونباخ Alpha Cronbachs لاختبار ثبات مقاييس البحث. • معامل الارتباط بيرسون للتحقق من صدق التكوين لمقاييس البحث. إختبار ت للتحقق من صحة فروض البحث. • حجم التأثير وايتا تربيع.

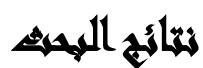

اختبار المعلومات: الفرض الأول: يوجد فرق دال إحصائيا عند مسنوي (ه.,.) بين متوسطى درجات اختبار المعارف البيئية لتلاميذ المرحلة الإعدادية (عينة البحث) قبل تطبيق البرنامج وبعده لصالح التطبيق البعدي.

$$
\begin{aligned}
& \text { المجلد الخمسون، العدد العاشر الجزء الثاني، أكتوبر اب.r } \\
& \text { الترقيم الدولي 0826-08S 1110 } \\
& \text { الترقيم الدولي الموحد الإلكتروني 3178-2636 }
\end{aligned}
$$


مجلة العلوم البيئية

كلية الدراسات العليا والبحوث البيئية - جامعة عين شمس البئة

مريم جورج عبد الثهيد وآخرون

جدول (V): نتائج اختبار (ت) لحساب دلالة الفروق بين متوسطي درجات عينة البحث في التطبيقين القبلي والبعدي اختبار المفاهيم البيئية

\begin{tabular}{|c|c|c|c|c|c|c|c|}
\hline \multirow{2}{*}{ مستوى } & \multirow{2}{*}{ قيمة (ت) } & \multicolumn{2}{|c|}{ 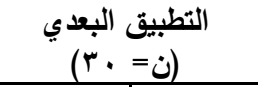 } & \multicolumn{2}{|c|}{ 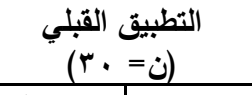 } & \multirow{2}{*}{ الكلية } & \multirow{2}{*}{ المتغيرات } \\
\hline & & الانحراف & المتوسط & الانحراف & المتوسط & & \\
\hline ' & $\Lambda, \vee 01$ & $\cdot, 77$ & $r, I V$ & $\cdot, 99$ & $\cdot, \wedge T$ & r & مشكلة تلوث الهواء \\
\hline 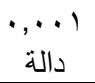 & $\wedge, 00$ & $\cdot, 99$ & $r, 1$. & 1,1 . & $1, r r$ & 0 & مشكلة المياه \\
\hline ( & $\Lambda, \leq \leq 9$ & $\cdot, 70$ & $1, v \cdot$ & $\cdot, \wedge 1$ & זד, • & r & ترشيد استهلاك الطاقة \\
\hline ( & 9, & $\cdot, \wedge \wedge$ & $r, r$. & $\cdot, \lambda r$ & $\cdot, \vee \vee$ & $\varepsilon$ & التلوث الضوضائى \\
\hline ( & רוזים & $\cdot, \vee \vee q$ & r,, . & $\cdot, \mathrm{V}$ & $\cdot, \vee \vee \top$ & $\varepsilon$ & المخلفات الصلبة \\
\hline ( & $\Lambda, \Sigma T r$ & • & $1,7 \mathrm{~V}$ & שזד, • & $\cdot, 0 \mathrm{~V}$ & $r$ & التتوع البيولوجى \\
\hline ( & $1 \cdot, I V r$ & $\cdot, \mathrm{VO}$ & $r, I V$ & $\cdot, 7 \uparrow$ & $\cdot, \leqslant \vee$ & $\varepsilon$ & التصحر \\
\hline | & $9,7 \wedge 0$ & $\cdot, 94$ & $r, \varepsilon$. & $\cdot, \wedge \wedge$ & $\cdot, T V$ & $\varepsilon$ & مشكلة تغير المناخ \\
\hline | & r), $9 \wedge$. & $r, 74$ & $I V, V$. & r, rq & 0,97 & $r$. & الدرجة الكلية اختبار \\
\hline
\end{tabular}

اتضح من الجدول السابق لحساب دلالة الفروق بين متوسطي درجات عينة البحث في التطبيقين القبلي والبعدي لاختبار المعلومات البيئية ما يلي: • توجد فروق ذات دلالة إحصائية بين متوسطي درجات عينة البحث لمشكلة نلوث الهواء

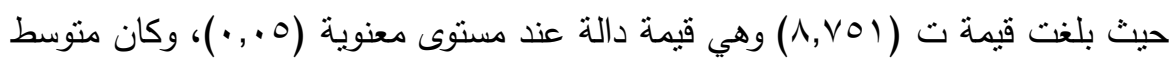

$$
\begin{aligned}
& \text { المجلد الخمسون، العدد العاشر الجزء الثاني، أكتوبر ب r.r. }
\end{aligned}
$$

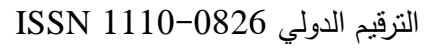

$$
\begin{aligned}
& \text { الترقيم الدولي الموحد الإلكتروني 3178-2636-26 التربي }
\end{aligned}
$$




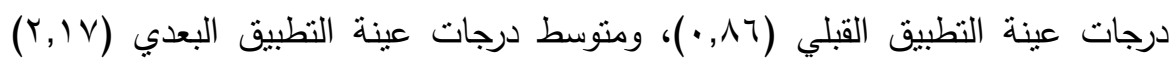
لصالح التطبيق البعدي.

توجد فروق ذات دلالة إحصائية بين متوسطي درجات عينة البحث لمشكلة المياه حيث

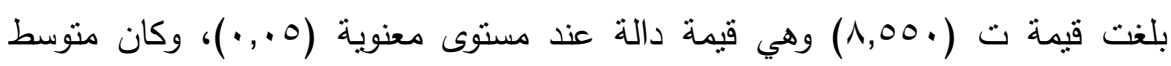

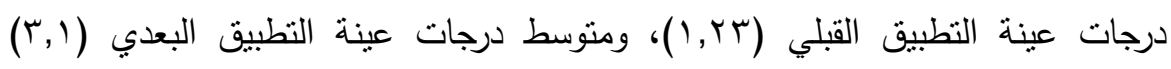
لصالح التطبيق البعدي. توجد فروق ذات دلالة إحصائية بين منوسطي درجات عينة البحث لترشيد استهلاك الطاقة

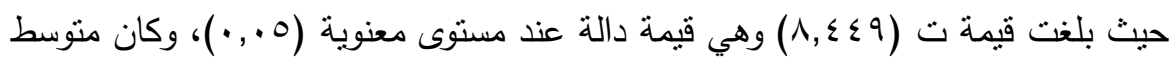

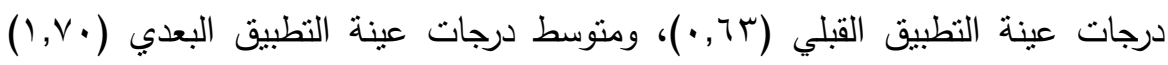
لصالح التطبيق البعدي. •توجد فروق ذات دلالة إحصائية بين متوسطي درجات عينة البحث للتلوث الضوضائى

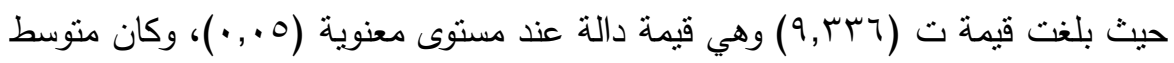
درجات عينة التطبيق القبلي (VV), ·,)، ومتوسط درجات عينة التطبيق البعدي (r,r) لصالح التطبيق البعدي. توجد فروق ذات دلالة إحصائية بين متوسطي درجات عينة البحث للمخلفات الصلبة

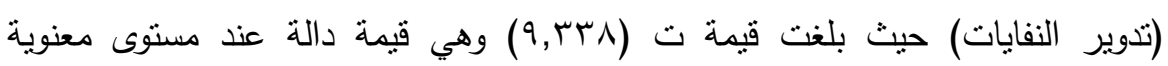

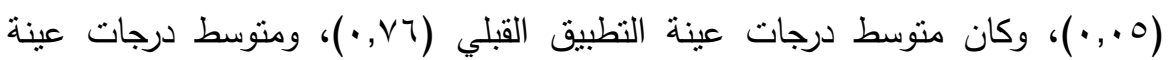
التطبيق البعدي (؟, r) لصالح التطبيق البعدي. توجد فروق ذات دلالة إحصائية بين منوسطي درجات عينة البحث للتنوع البيولوجى حيث

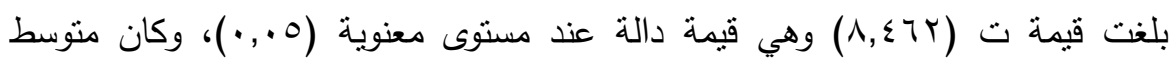




\section{مجلة العلوم البيئية \\ كلية الدراسات العليا والبحوث البيئية - جامعة عين شمس البئة

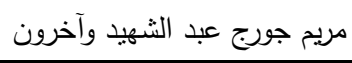

درجات عينة التطبيق القبلي (OV,·)، ومتوسط درجات عينة التطبيق البعدي (VT, ( ) لصالح التطبيق البعدي.

• توجد فروق ذات دلالة إحصائية بين منوسطي درجات عينة البحث للتصحر حيث بلغت

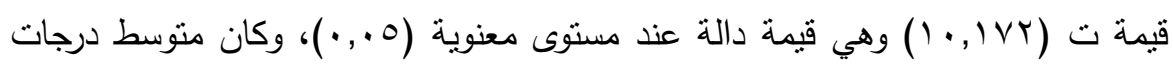

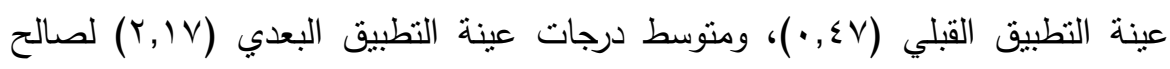
التطبيق البعدي. • توجد فروق ذات دلالة إحصائية بين منوسطي درجات عينة البحث لمشكلة تغير المناخ

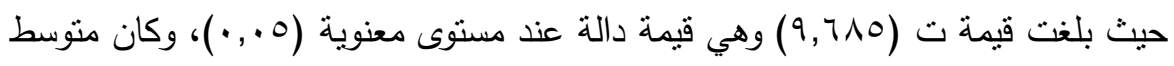

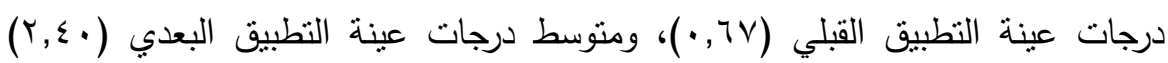
لصالح التطبيق البعدي. توجد فروق ذات دلالة إحصائية بين متوسطي درجات عينة البحث للارجة الكلية لاختبار

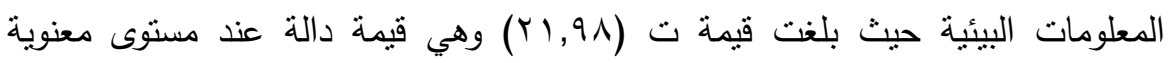
(0., •)، وكان منوسط درجات عينة التطبيق القبلي (97,97)، ومنوسط درجات عينة التطبيق البعدي (lv,v) لصالح التطبيق البعدي.

$$
\begin{aligned}
& \text { المجلد الخمسون، العدد العاشر الجزء الثاني، أكتوبر ب r.r. } \\
& \text { الترقيم الدولي 0826-0 1110 } \\
& \text { الترقيم الدولي الموحد الإلكتروني 3178-2636-26 }
\end{aligned}
$$




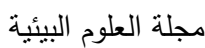

كلية الدراسات العليا والبحوث البيئية - جامعة عين شس البئ

مريم جورج عبد الثهيد وآخرون

جدول (^): نتائج حجم التأثنر لاختبار المعلومات البيئية

\begin{tabular}{|c|c|c|c|}
\hline مقار حجم التأثير & قيمة d ق & قيمة ايتا؟ & المتغيرات \\
\hline متوسط & $\cdot, 7 Y 0$ & $\cdot, r q$. & مشكلة تلوث الهواء \\
\hline متوسط & $\cdot, 7 V$ & $\cdot, \leqslant \leqslant 9$ & مشكلة المياه \\
\hline متوسط &., $09 \leqslant$ & . ror & ترشيد استهلاك الطاقة \\
\hline متوسط & $\cdot, \mathrm{TVV}$ & $\cdot, \leqslant 0 \wedge$ & التلوث الضوضائى \\
\hline متوسط & $\cdot, \times 10$ &., $01 Y$ & المخلفات الصلبة (تدوير النفايات) \\
\hline متوسط & $\cdot, 707$ & $\cdot, \varepsilon r$ & التتوع البيولوجى \\
\hline متوسط & $\cdot, \vee \vee \vee 1$ &., $09 \varepsilon$ & التصحر \\
\hline متوسط & $\cdot, 797$ & $\cdot, \leqslant \wedge 0$ & مشكلة تغير المناخ \\
\hline كبير &., $9 Y Y$ & $\cdot, 10$ & الدرجة الكلية اختبار المعلومات البيئية \\
\hline
\end{tabular}

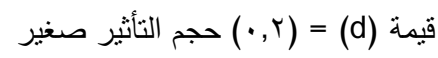

قيمة (d) = (d, (·, ) حجم الثأثير متوسط

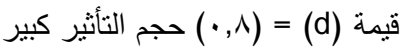

اتضح من الجدول السابق لنتائج حجم النأثير لاختبار المعلومات البيئية ما يلي:

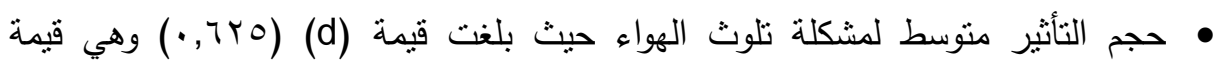

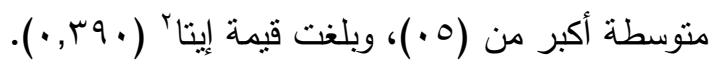

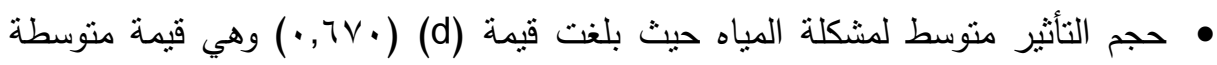

$$
\text { أكبر من (0.)، وبلغت قيمة إيتا' (1979, • •). }
$$

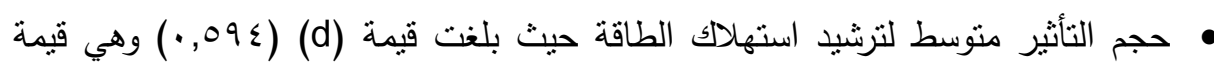

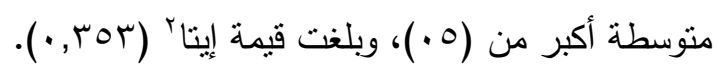

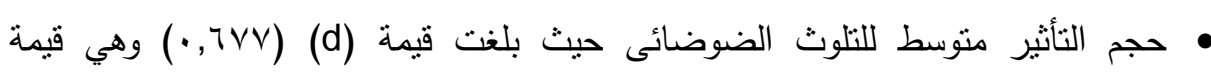

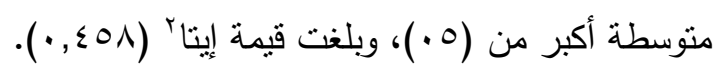

420

$$
\begin{aligned}
& \text { المجلد الخمسون، العدد العاشر الجزء الثاني، أكتوبر ب r.r. } \\
& \text { التزقيم الدولي 0826- ISSN 1110 } \\
& \text { الترقيم الدولي الموحد الإلكتروني 3178-2636-26 }
\end{aligned}
$$




\section{مجلة العلوم البيئية \\ كلية الدراسات العليا والبحوث البيئية - جامعة عين شمس لبه \\ مريم جورج عبد الثهيد وآخرون}

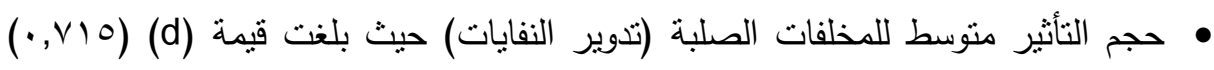

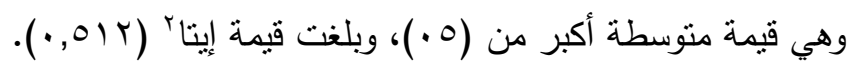

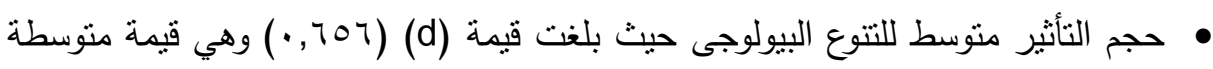

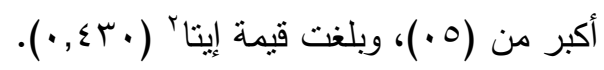

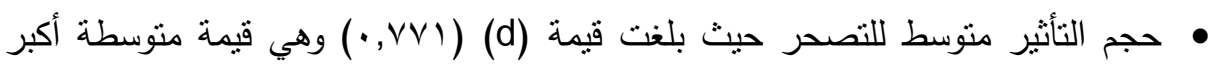

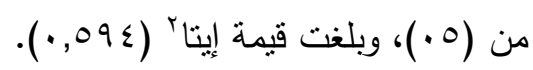

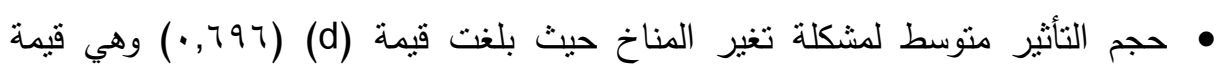

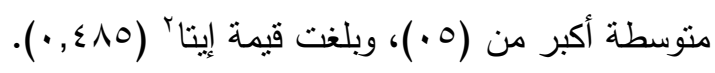

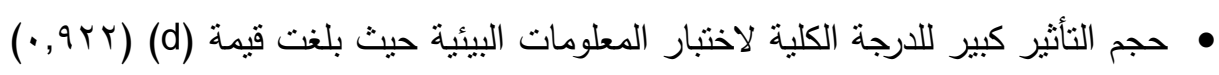

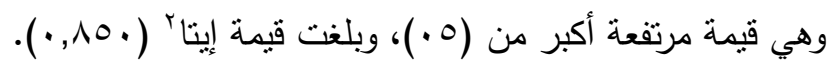

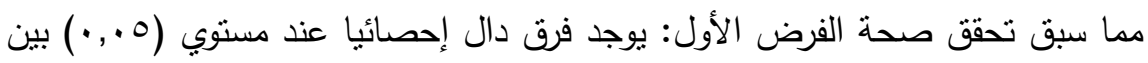

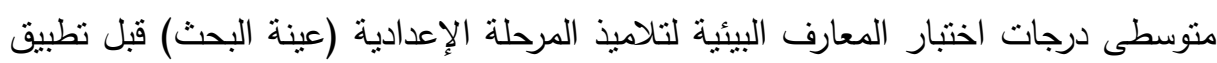
البرنامج وبعده لصالح التطبيق البعدي.

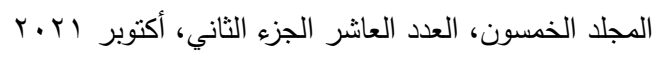

$$
\begin{aligned}
& \text { الترقيم الدولي 0826-0 1110 } \\
& \text { الترقيم الدولي الموحد الإلكتروني 3178-2636-26 التربي }
\end{aligned}
$$




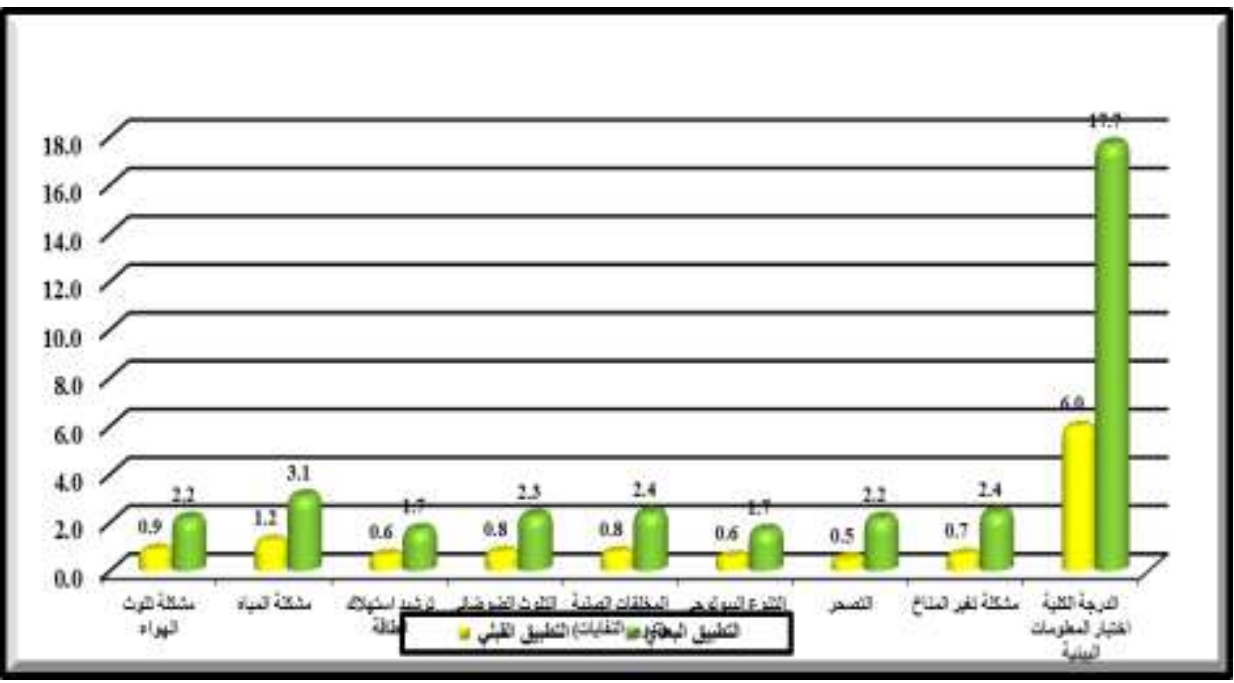

شكل (1): الفروق بين منوسطي درجات عينة البحث في النطبيقين القبلي والبعدي لاختبار المعارف البيئية

هذه النتيجة اتفقت مع دراسة: (رشا عبد الدايم، Y V V V) فاعلية برنامج قائم على توظيف

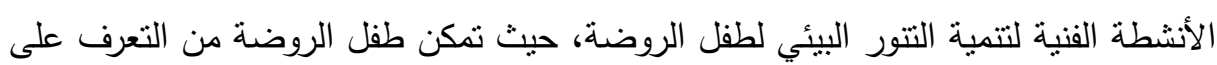

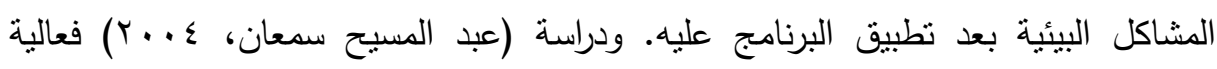
برنامج لتتمية المعلومات البيئية لاى معلمى العلوم بالمرحلة الأعدادية. ودراسة (عماد عادل

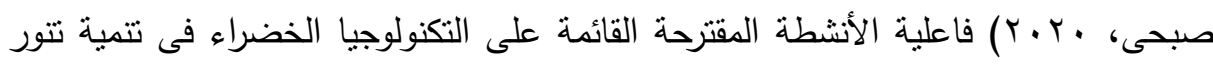
التلاميذ بمفاهيم التكنولوجيا الخضراء من حيث زيادة معلوماتهم المتعلقة بالتكنولوجيا الخضراء.

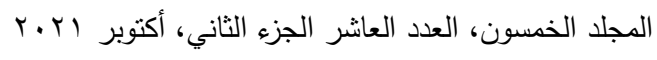

$$
\begin{aligned}
& \text { الترقيم الدولي 0826-08S 1110 } \\
& \text { الترقيم الدولي الموحد الإكتروني 3178-2636 }
\end{aligned}
$$




\section{نتائج تطبيق مقياس الأتجاهات:}

الفرض الثاني: يوجد فرق دال إحصائيا عند مستوي (0.0. .•) بين متوسطى درجات مقياس الإناس الأتجاهات البيئية لتلاميذ المرحلة الإعدادية (عينة البحث) قبل تطبيق البرنامج وبعده لصالح

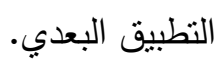
جدول (9): نتائج اختبار (ت) لحساب دلالة الفروق بين متوسطي درجات عينة البحث في البئي التطبيقين القبلي والبعدي لمقياس الاتجاهات البيئية

\begin{tabular}{|c|c|c|c|c|c|c|c|}
\hline \multirow{2}{*}{ مستولة الدالة } & \multirow{2}{*}{ قيمة } & \multicolumn{2}{|c|}{ التطبيق البعدي } & \multicolumn{2}{|c|}{ التطبيق القبلي } & \multirow{2}{*}{ الالارجة } & \multirow{2}{*}{ المتغيرات } \\
\hline & & الانحراف & المتوسط & الاتحراف & المتوسط & & \\
\hline دالة., & $r, N \mid r$ & $1, .0$ & $10,1 \mathrm{~V}$ & $1, \leqslant 0$ & $\vee, 9 V$ & Ir & مشكلة المباه \\
\hline دالة, & $1 \wedge, \leqslant 0 \leqslant$ & 1,01 & $11, v$. & $1,1 \pi$ & $ד, r v$ & 1. & الدخلفات الصلبة \\
\hline دالة, & $r r, \cdot V V$ & $1,0 Y$ & $1 \varepsilon, r$. & $1,1 \mathrm{~V}$ & $\wedge, \cdots$ & Ir & ترشيد استهالاكك \\
\hline دالة, & $\mid V, V O \varepsilon$ & $1, \cdots$ & $V, r$. & $\cdot, 9$. & $r, \wedge V$ & 7 & التلوث الضوضائى \\
\hline $\begin{array}{l}\text { دالة, } \\
\\
\end{array}$ & 19,1 Y & $1, .0$ & $q, \wedge r$ & $\cdot, 10$ & $0, \cdot r$ & $\wedge$ & مشكلة تلوث الهواء \\
\hline دالة, & $1 V, Y 9 q$ & $1, \cdot \varepsilon$ & $V$, or & $\cdot, \wedge \wedge$ & $\Gamma, T V$ & 7 & التتوع البيولوجى \\
\hline دالة, & $1 V, r 94$ & ז ה, • & $V, V r$ & $1, \cdot 1$ & $r, V r$ & 1 & مشكلة الاحتباس \\
\hline دالة & $O r, \wedge \leqslant r$ & $r, O$. & VT, rV & $T, \mu V$ & r & 7. & لمقياس الإتجاتهاهات الكلية \\
\hline
\end{tabular}

اتضح من الجدول السابق لحساب دلالة الفروق بين متوسطي درجات عينة البحث في

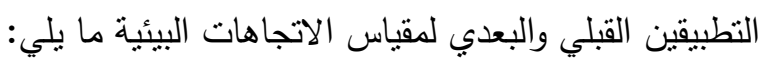

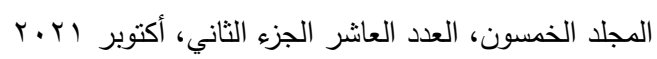

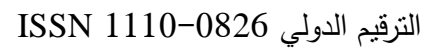

الترقيم الدولي الموحد الإلكتروني 3178-2636 
•وجد فروق ذات دلالة إحصائية بين متوسطي درجات عينة البحث لمشكلة المياه حيث

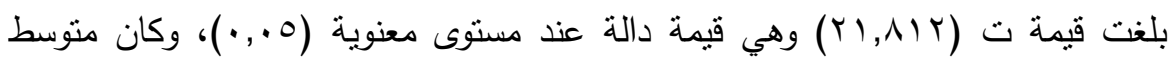

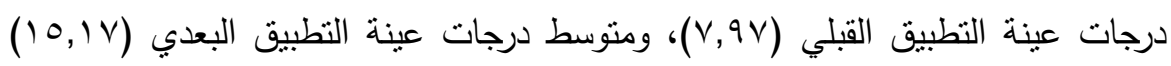
لصالح التطبيق البعدي. توجد فروق ذات دلالة إحصائية بين متوسطي درجات عينة البحث للمخلفات الصلبة

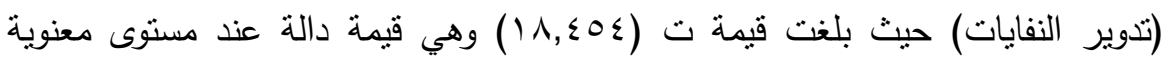

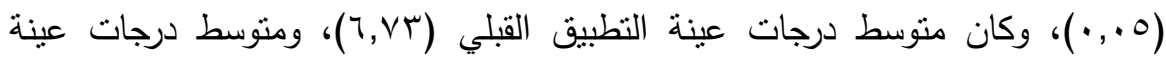
التطبيق البعدي (1,V) (1) لصالح التطبيق البعدي. توجد فروق ذات دلالة إحصائية بين متوسطي درجات عينة البحث لترشيد استهلاك الطاقة حيث بلغت قيمة ت (Yr,VV) وهي قيمة دالة عند مستوى معنوية (0., (•)، وكان

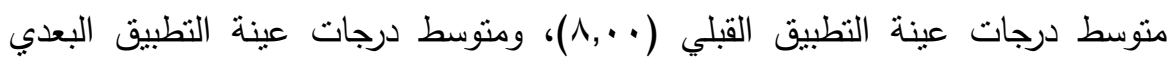

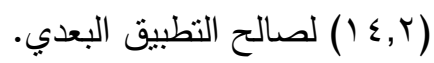
توجد فروق ذات دلالة إحصائية بين منوسطي درجات عينة البحث للتلوث الضوضائى

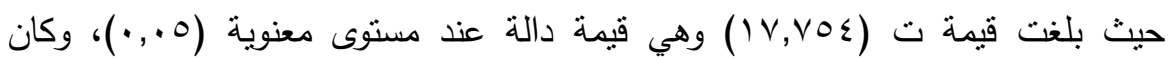
متوسط درجات عينة التطبيق القبلي (r,Av)، ومتوسط درجات عينة التطبيق البعدي

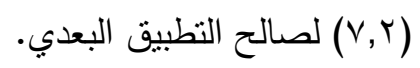
توجد فروق ذات دلالة إحصائية بين منوسطي درجات عينة البحث لمشكلة نلوث الهواء

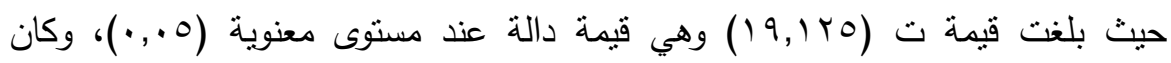
متوسط درجات عينة النطبيق القبلي (r.,0)، ومتوسط درجات عينة النطبيق البعدي ( ) الصالح التطبيق البعدي.

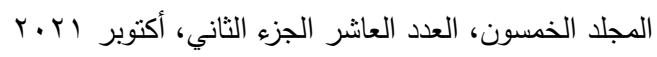

$$
\begin{aligned}
& \text { الترقيم الدولي 0826-0 1110 } \\
& \text { الترقيم الدولي الموحد الإلكتروني 3178-2636-26 }
\end{aligned}
$$


• توجد فروق ذات دلالة إحصائية بين متوسطي درجات عينة البحث للتتوع البيولوجى حيث

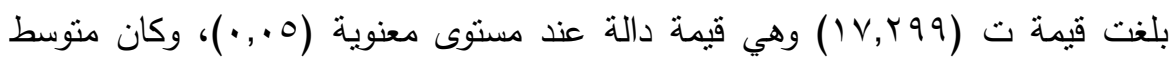

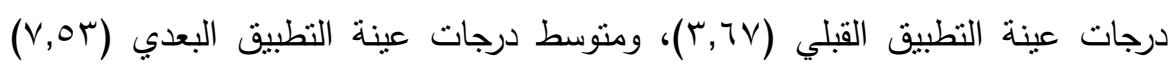
لصالح التطبيق البعدي. توجد فروق ذات دلالة إحصائية بين منوسطي درجات عينة البحث لمشكلة الاحتباس

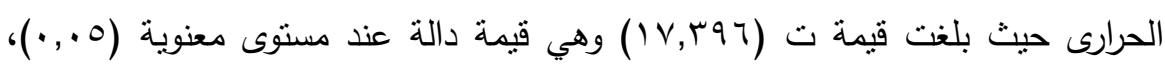

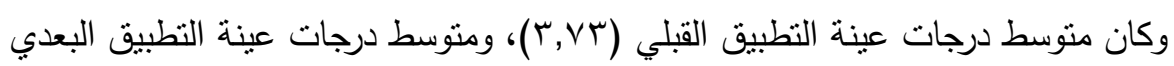

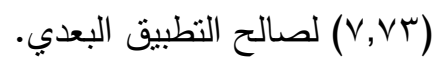

توجد فروق ذات دلالة إحصائية بين متوسطي درجات عينة البحث للارجة الكلية لمقياس

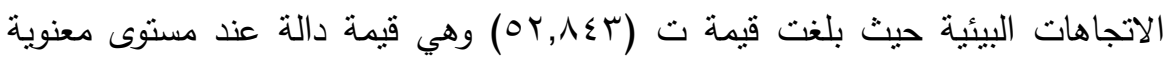

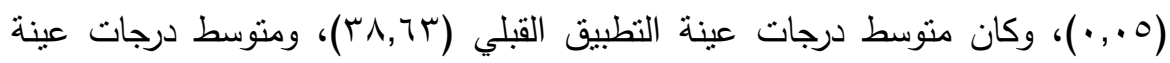

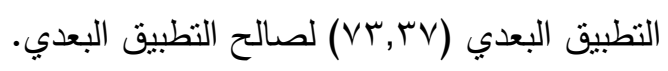
جدول ( • 1): نتائج حجم التأثير لمقياس الاتجاهات البيئية

\begin{tabular}{|c|c|c|c|}
\hline مقدار حجم التأثير & قيمة & قيمة ايتا؟ & المتغيرات \\
\hline كبير & $\cdot, 9 \leq 0$ & $\cdot, \wedge 9 \mu$ & مشكلة المياه \\
\hline كبير & $\cdot, \wedge 9 \vee$ & $\cdot, \wedge \cdot 0$ & المخلفات الصلبة (تدوير النفايات) \\
\hline كبير & $\cdot, 919$ & $\cdot, \wedge \leq \varepsilon$ & ترشيد استهلاك الطاقة \\
\hline كبير & $\cdot, \Lambda \vee r$ & $\cdot, \vee \vee T 1$ & التلوث الضوضائى \\
\hline كبير & $\cdot, 941$ & $\cdot, \wedge T \mathrm{~V}$ & مشكلة تلوث الهواء \\
\hline كبير & $\cdot, \wedge 9 \wedge$ & $\cdot, \Lambda \cdot 7$ & التتوع البيولوجى \\
\hline كبير & $\cdot, 9 \cdot \varepsilon$ & $\cdot, \wedge) \vee$ & مشكلة الاحتباس الحرارى \\
\hline كبير - كير & $\cdot 991$ & $\cdot 9 \wedge 1$ & الدرجة الكلية لمقياس الاتجاهات البيئية \\
\hline
\end{tabular}

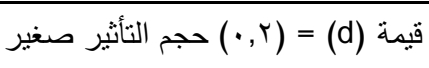

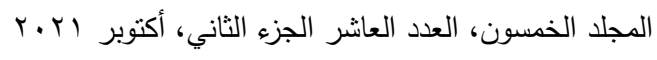

$$
\text { الترقيم الدولي 0826- ISSN 1110 }
$$

الترقيم الدولي الموحد الإلكتروني 3178-2636-26 الترب 


$$
\begin{aligned}
& \text { قيمة (d) = (0, (·) ) حجم الثأثير متوسط } \\
& \text { قيمة (d) = (d, (d) (d, ) حجم التأثير كبير }
\end{aligned}
$$

اتضح من الجدول السابق لنتائج حجم التأثنر لمقياس الاتجاهات البيئية ما يلي:

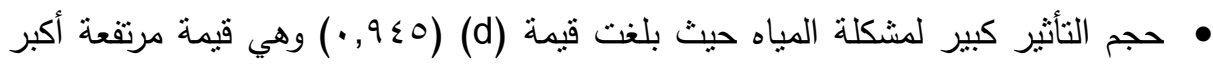

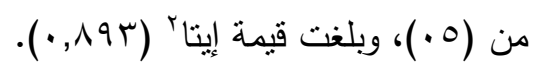

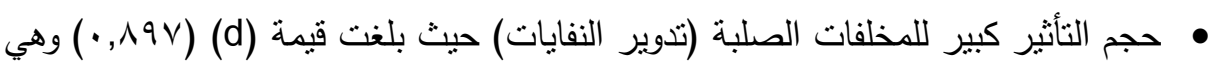

$$
\text { قيمة مرتفعة أكبر من (ه •)، وبلغت قيمة إيتا ( (. A, • ). }
$$

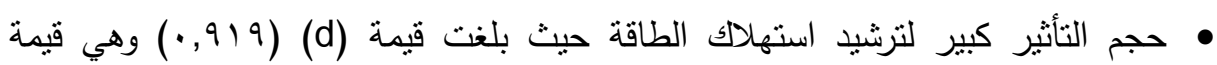

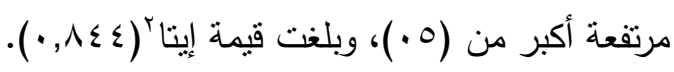

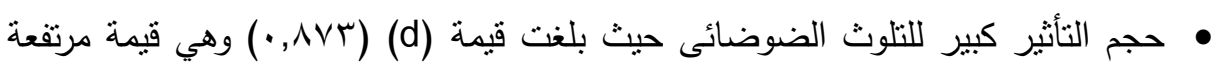

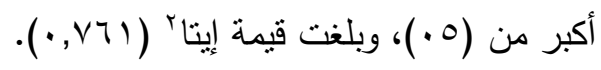

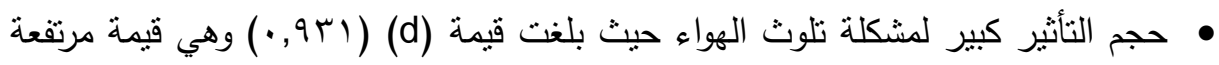

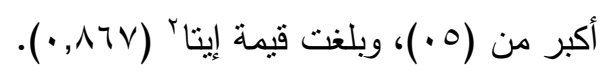

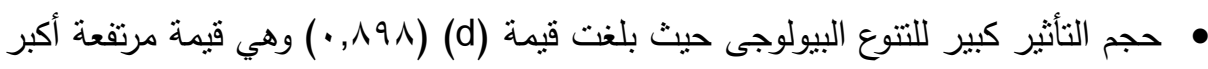

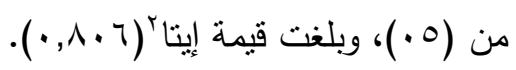

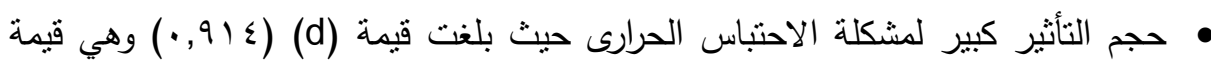

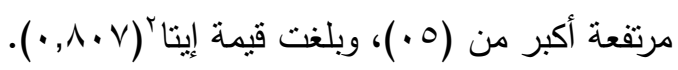

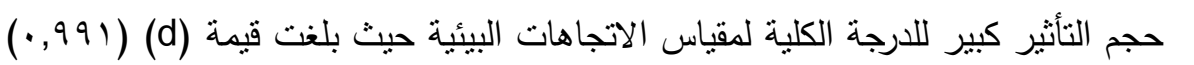

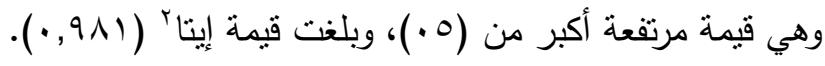


كلية الدراسات العليا والبحوث البيئية - جامعة عين شمس لئه

مريم جورج عبد الثهيد وآخرون

مما سبق تحقق صحة الفرض الثاني: يوجد فرق دال إحصائيا عند مستوي (ه.,.) بين

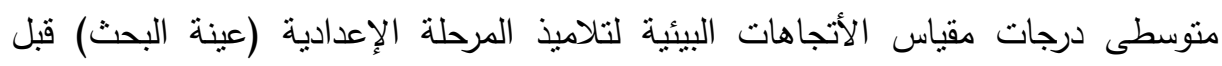
تطبيق البرنامج وبعده لصالح التطبيق البعدي.

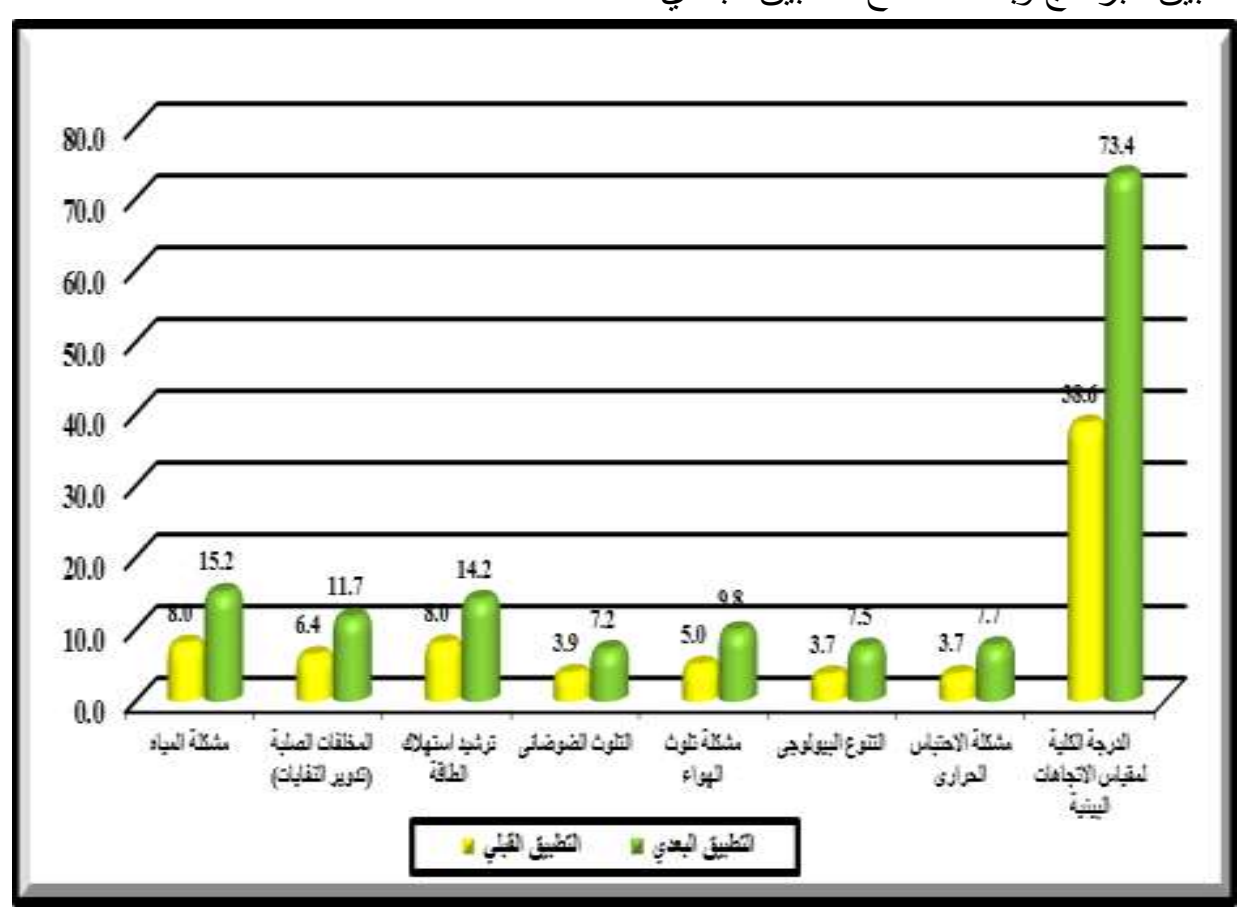

شكل (Y): الفروق بين منوسطي درجات عينة البحث في التطبيقين القبلي والبعدي لمقياس الاتجاهات البيئية

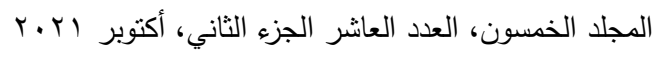

الترقيم الدولي 0826-0 1110 110

الترقيم الدولي الموحد الإكتروني 3178-2636 
واتفقت هذة النتائج مع دراسة : (نادية محمد على العطاب، 17 ـ r) فاعلية مقرر التربية البيئية فى تحقيق اتجاهات إيجابية بيئية لدى طلبة قسم الكيمياء بالجامعة. وايضاً أكدت دراسة

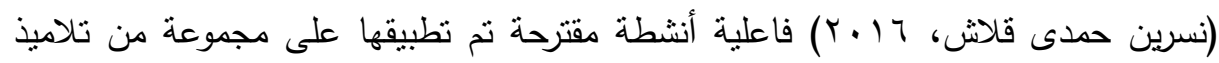
الصف الثانى الإعدادى فى نتمية الإتجاهات نحو المحافظة على البيئة.

نتائج تطبيق مقياس المهارات: الفرض الثالث: يوجد فرق دال إحصائيا عند مستوي (0., •) بين متوسطى درجات مقياس المهارات البيئية لتلاميذ المرحلة الإعدادية (عينة البحث) قبل تطبيق البرنامج وبعده لصالح التطبيق البعدي.

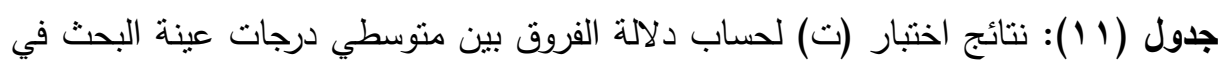
التطبيقين القبلي والبعدي لمقياس المهارات البيئية

\begin{tabular}{|c|c|c|c|c|c|c|c|}
\hline \multirow{2}{*}{ مستوى } & \multirow[t]{2}{*}{ قيمة (ت) } & \multicolumn{2}{|c|}{ 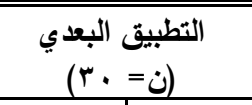 } & \multicolumn{2}{|c|}{ التطبيق القبلي } & \multirow[t]{2}{*}{ الارجة } & \multirow[t]{2}{*}{ المتغيرات } \\
\hline & & الانحراف & المتوسط & الانحراف & المتوسط & & \\
\hline 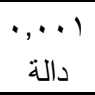 & rV,TOV & 1,19 & $17, \varepsilon$ & $1, \varepsilon r$ & T, \&. & $r$. & تحديد المشكلة \\
\hline 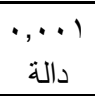 & $r \cdot, \wedge 91$ & $1, .9$ & $\Lambda, 1$ & $1, r$. & $r, 1$ & 1. & حل الشكلة \\
\hline 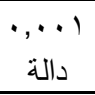 & $\leqslant 1, \wedge 9$. & זr, & $T \leqslant, 0$ & $1, \times 7$ & $\Lambda, 0$ & $r$. & الدرجة الكلية لمقياس المهارات البيئية \\
\hline
\end{tabular}

اتضح من الجدول السابق لحساب دلالة الفروق بين متوسطي درجات عبنة البحث في التطبيقين القبلي والبعدي لمقياس المهارات البيئية ما يلي: • توجد فروق ذات دلالة إحصائية بين متوسطي درجات عينة البحث لتحديد المشكلة حيث

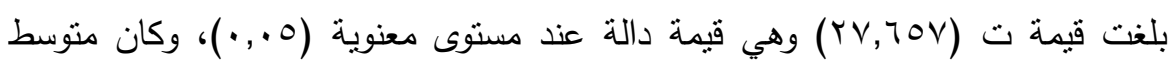


درجات عينة التطبيق القبلي (ع,7)، ومتوسط درجات عينة التطبيق البعدي (؟,7 (1) لصالح التطبيق البعدي.

• توجد فروق ذات دلالة إحصائية بين منوسطي درجات عينة البحث لحل المشكلة حيث

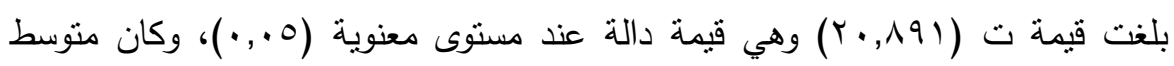

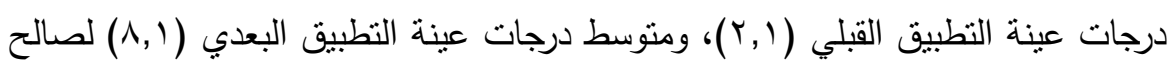
التطبيق البعدي.

• نوجد فروق ذات دلالة إحصائية بين متوسطي درجات عينة البحث للارجة الكلية لمقياس

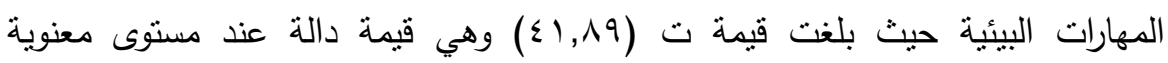
(0., (•)، وكان منوسط درجات عينة النطبيق القبلي (^,0)، ومتوسط درجات عينة

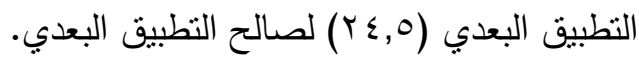
جدول (r r ): نتائج حجم التأثير لمقياس المهارات البيئية

\begin{tabular}{|c|c|c|c|}
\hline مقدار حجم التأثير & قيمة d ق & قيمة ايتا؟ & المتغيرات \\
\hline كبير &., 971 & $\cdot 9,9 \mathrm{~V}$ & تحديد المشكلة \\
\hline كبير &., 947 & $\cdot, \wedge \vee_{0}$ & حل المشكلة \\
\hline كبير &., $9 \wedge \mathrm{r}$ &., $97 \varepsilon$ & الدرجة الكلية لمقياس الدهارات البيئية \\
\hline
\end{tabular}

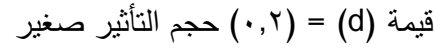

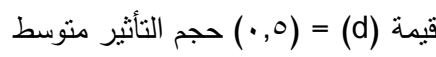
قيمة (d) = (d, (·, ) حجم التأثير كبير

اتضح من الجدول السابق لنتائج حجم التأثير لمقياس المهارات البيئية ما يلي:

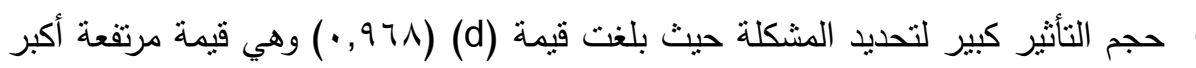

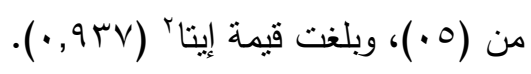

$$
\begin{aligned}
& \text { المجلد الخمسون، العدد العاشر الجزء الثاني، أكتوبر ب r.r. } \\
& \text { الترقيم الدولي 0826-0 1110 } \\
& \text { الترقيم الدولي الموحد الإلكتروني 3178-2636-26 التربي }
\end{aligned}
$$


• حجم التأثير كبير لحل المشكلة حيث بلغت قيمة (d) (بrو, , ) وهي قيمة مرتفعة أكبر

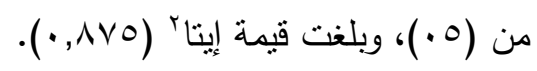

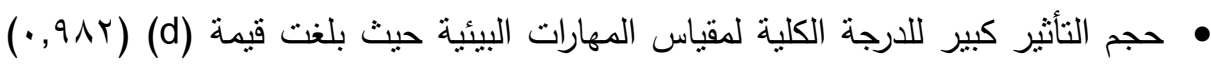

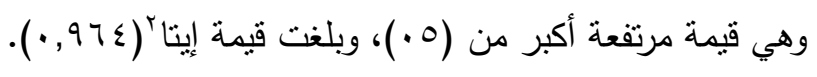

مما سبق تحقق صحة الفرض الثالث: يوجد فرق دال إحصائيا عند مستوي (0. (., •) بين منوسطى درجات مقياس المهارات البيئية لتلاميذ المرحلة الإعدادية (عينة البحث) قبل تطبيق

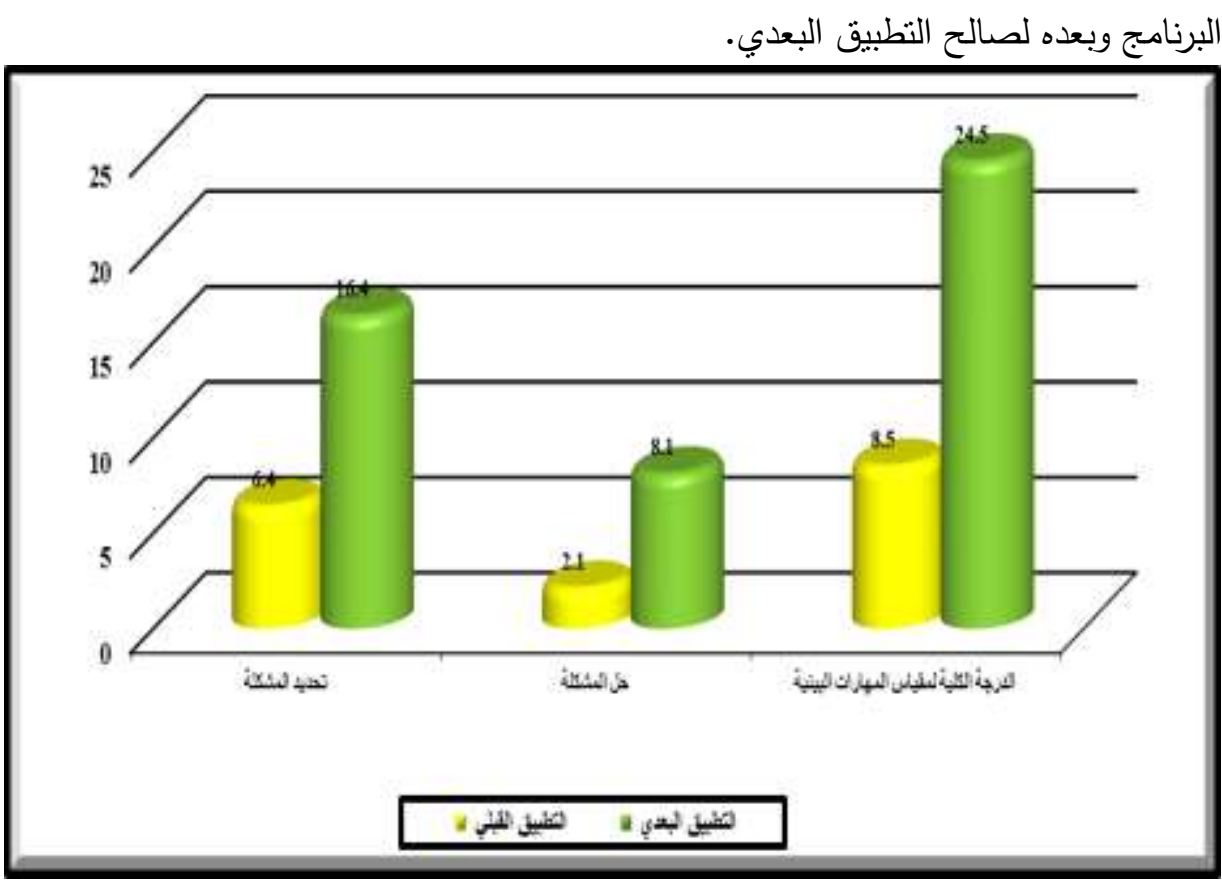

شكل (ऍ): الفروق بين متوسطي درجات عينة البحث في التطبيقين القبلي والبعدي لمقياس

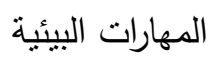

430

$$
\begin{aligned}
& \text { المجلد الخمسون، العدد العاشر الجزء الثاني، أكتوبر ب r.r. }
\end{aligned}
$$

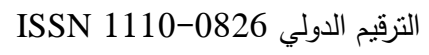

$$
\begin{aligned}
& \text { الترقيم الدولي الموحد الإلكتروني 3178-2636-26 }
\end{aligned}
$$




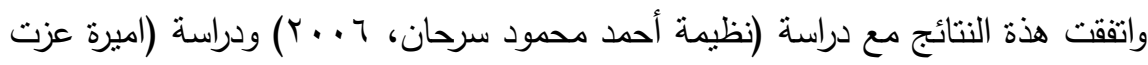

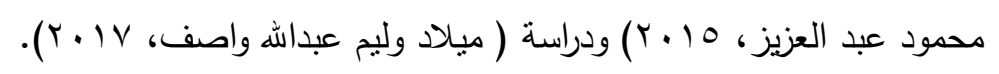
القرض الرئيسي: يوجد فرق دال إحصائيا عند مستوي (0.,.) بين متوسطى درجات تلاميذ المجموعة التجريبية (عينة البحث) فى مقياس النتور البيئى فبل وبعد تعرضهم لبرنامج الوسائل الإرشادية بإستخدام فن الجرافيك لصالح التطبيق البعدى.

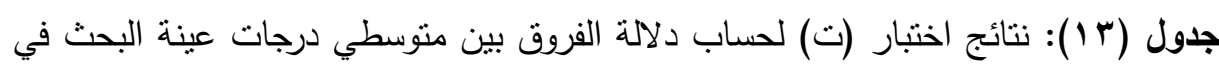
التطبيقين القبلي والبعدي لمقياس المهارات البيئية

\begin{tabular}{|c|c|c|c|c|c|c|c|}
\hline \multirow{2}{*}{ مالدلالة } & \multirow{2}{*}{ قيمة (ت) } & \multicolumn{2}{|c|}{ 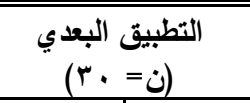 } & \multicolumn{2}{|c|}{ 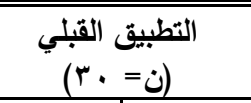 } & \multirow{2}{*}{ الارجة } & \multirow{2}{*}{ المتغيرات } \\
\hline & & الانحراف & المتوسط & الانحراف & المتوسط & & \\
\hline 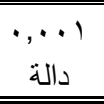 & OА, VAN & $\varepsilon, \Gamma$ & 110,7 & $r, q$ & or, 1 & Ir. & الدرجة الكلية لمقياس \\
\hline
\end{tabular}

اتضح من الجدول السابق لحساب دلالة الفروق بين منوسطي درجات عينة البحث في

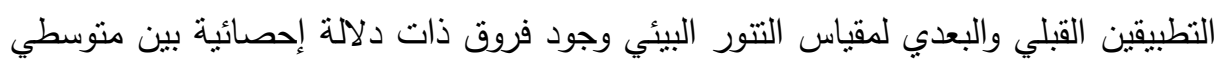

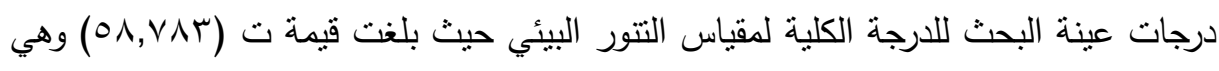
قيمة دالة عند مستوى معنوية (0., ) )، وكان منوسط درجات عينة التطبيق القبلي (1, (به)،

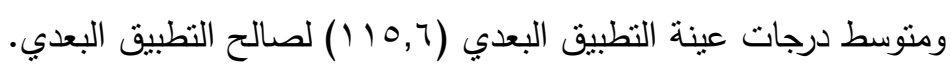
جدول (؛ ا ): نتائج حجم التأثير لمقياس المهارات البيئية

\begin{tabular}{|c|c|c|c|}
\hline مقدار حجم التأثثر & قيمة d d & قيمة ايتا؟ & المتغيرات \\
\hline كبير & $\cdot, 99 r$ & $\cdot, 9 \wedge \varepsilon$ & الدرجة الكلية لمقياس التتور البيئي \\
\hline
\end{tabular}

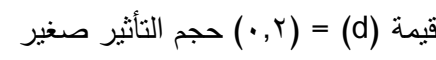

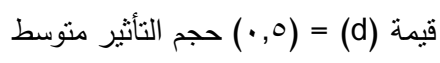

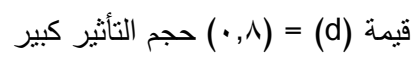

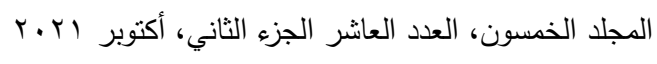
431

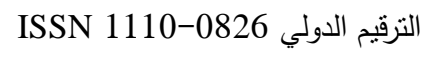
الترقيم الدولي الموحد الإككتروني 3178-2636 الني 
اتضح من الجدول السابق لننائج حجم النأثير لمقياس التنور البيئي أن حجم النأثير كبير

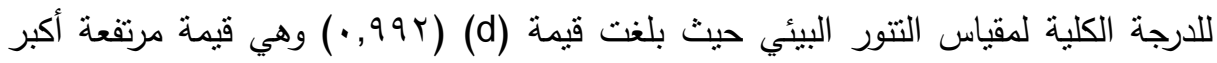

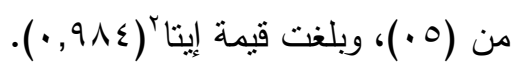

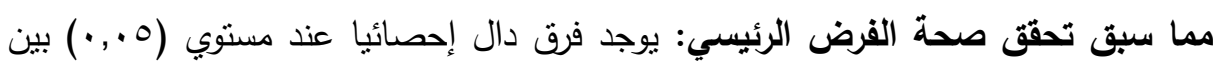

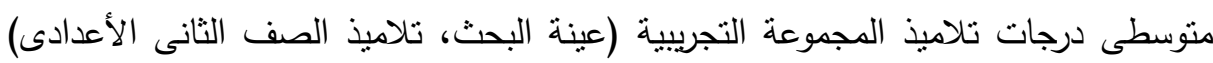

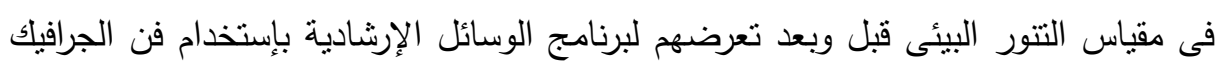

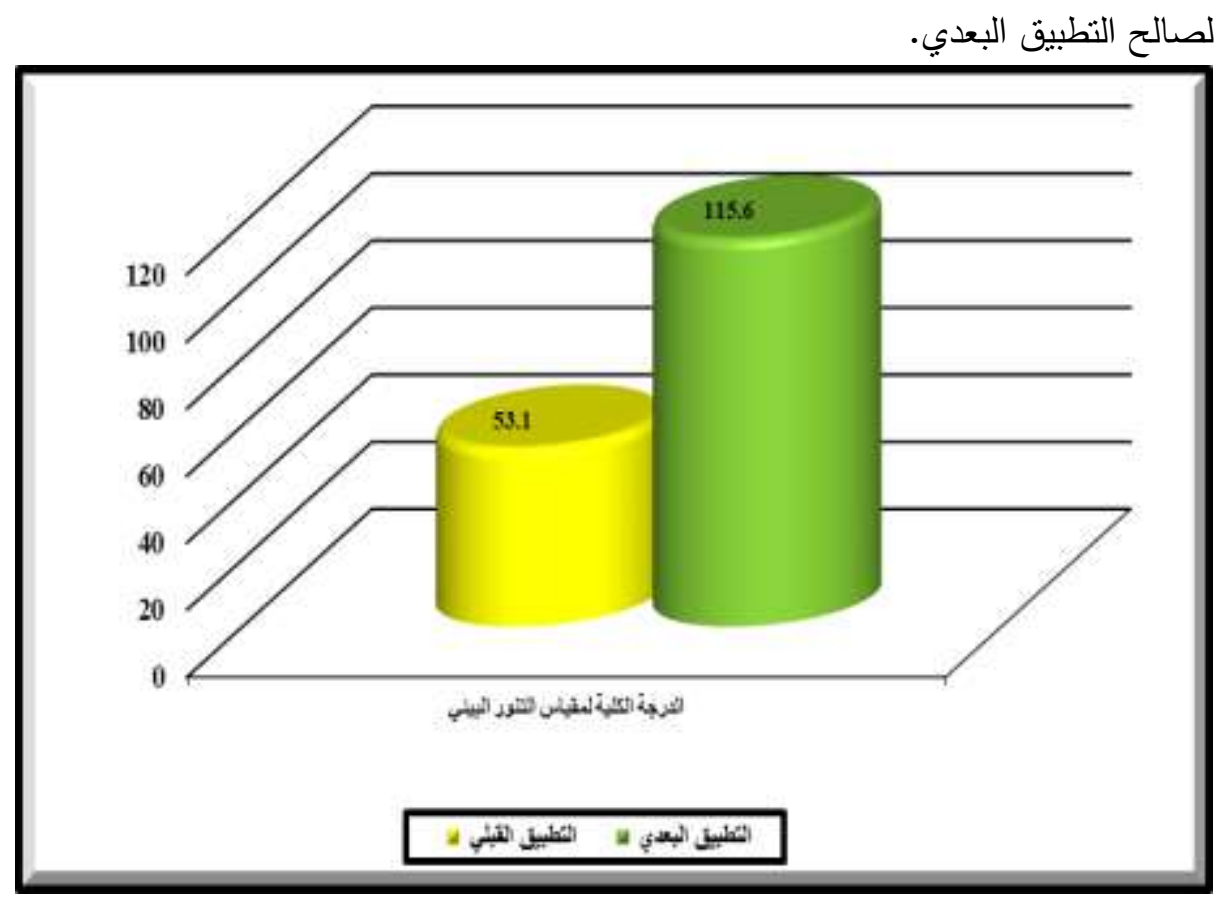

شكل (؛): الفروق بين متوسطي درجات عينة البحث في التطبيقين القبلي والبعدي لمقياس

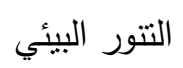

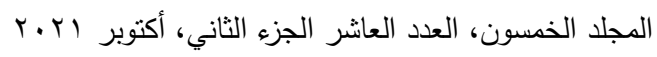

$$
\begin{aligned}
& \text { الترقيم الدولي 0826-1110 } \\
& \text { الترقيم الدولي الموحد الإلكتروني 3178-2636-26 }
\end{aligned}
$$


التعليق العام على النتائج: يتضح من خلال نتائج مقياس التتور البيئي أن إنتاج الوسائل الأرشادية بأستخدام فن الجرافيك نتج عنه تتمية تتور التلاميذ فى المعارف البيئية والأتجاهات والمهارات البيئية، ويرجع ذللك إلى التتوع فى التصميمات والوسائل الإرشادية والتى يتم التعامل

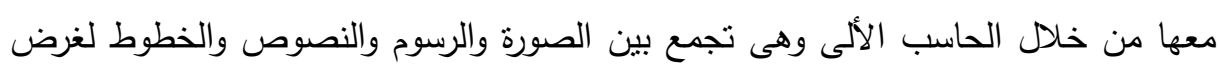

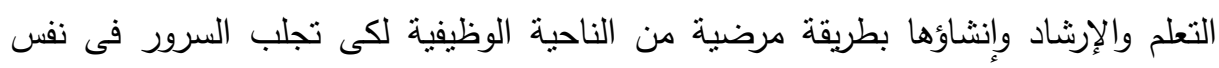

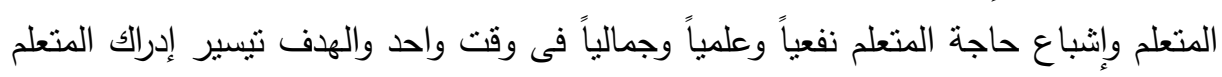

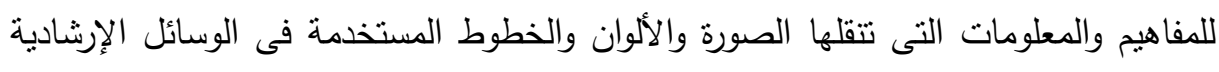
والتصميم يعبر عن الأفكار والمفاهيم وينقلها للمتعلم ويهدف إلى التوعية بوجود المشكلة والعمل على حلها فهو يرشد المتعلم ويساعد على تغير إتجاهاته وسلوكه.

\section{اللموصيايتص}

• عقد دورات تدريبية متخصصة فى مجال الجرافيك للمدرسين والمختصين بالأنشطة والوسائل الأرشادية . ثورات

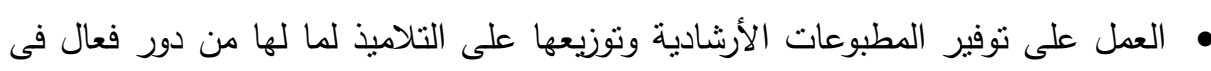

تحقيق الغرض منها.

• دعوة الجهات المسئولة إلى وضع جدول زمنى لتعليم مهارة انتاج وسيلة إرشادية لدورها الإيجابى على سلوكيات التلاميذ.

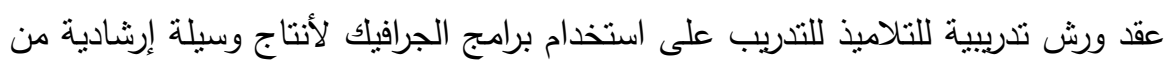
خلا المتخصصين فى مجال الجرافيك لدورها الفعال فى تتمية التتور البيئى لدى التلاميذ.

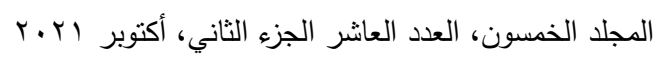

$$
\begin{aligned}
& \text { التزقيم الدولي 0826- ISSN 1110 } \\
& \text { الترقيم الدولي الموحد الإككتروني 3178-2636 الني }
\end{aligned}
$$




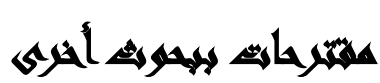

• إعداد دراسة تتضمن تصميم برنامج تدريبي للمعمين عن أهمية التأثير البصرى على

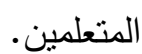

• أن تهتم الدراسات المستقلية بالتعرف على المتغيرات المستقلة الأخرى التى لها علاقة بإستخدام الطرق الإرشادية وتأثنيرها على المتعلمين.

\section{المراليجا}

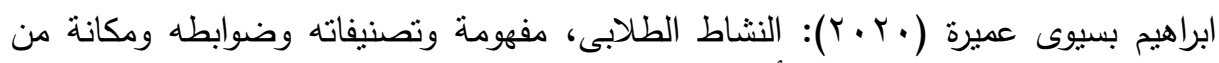

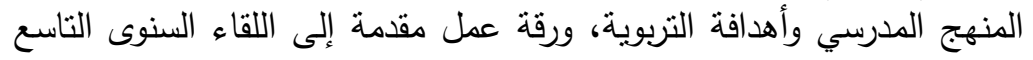

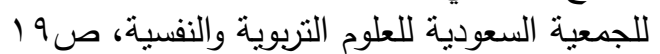

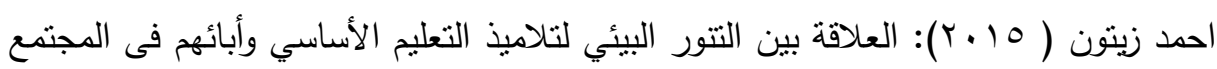

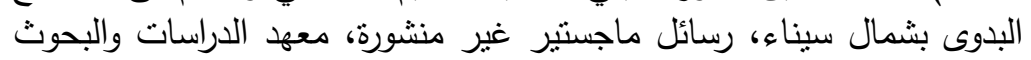
البيئية، جامعة عين شمس.

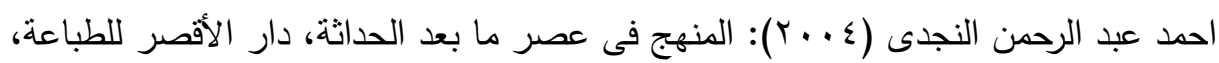

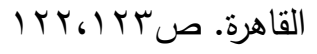

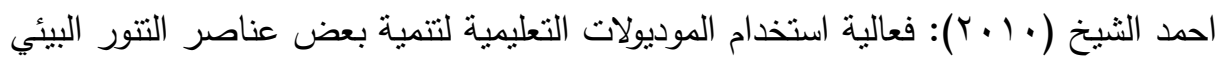

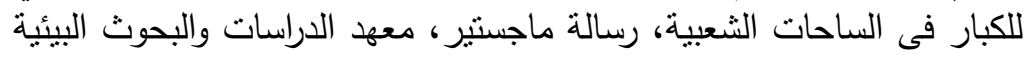
جامعة عين شمس. صات صبr

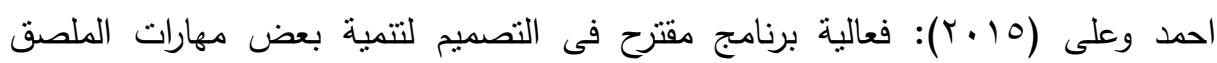

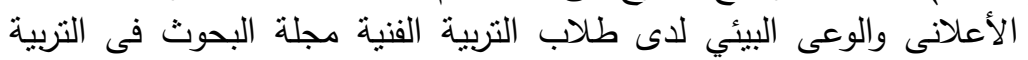

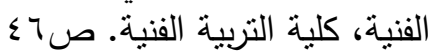

الراوى، نزار (11 (Y): مبادئ تصميم الجرافيك،ثار أوثر هاوس للنشر ، الولايات المتحدة الأمريكية.

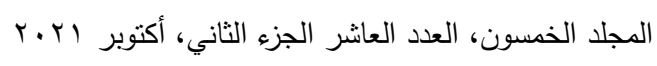

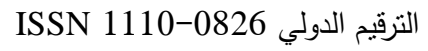

$$
\begin{aligned}
& \text { الترقيم الدولي الموحد الإلكتروني 3178-2636 }
\end{aligned}
$$




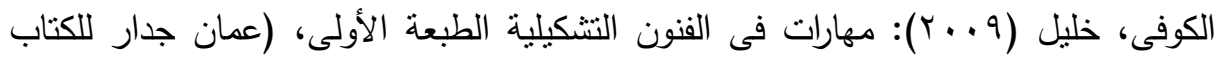

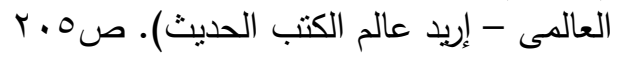

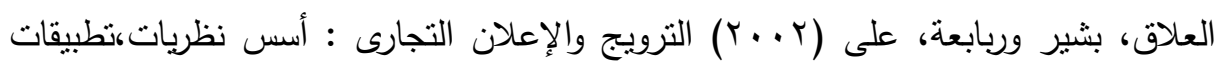

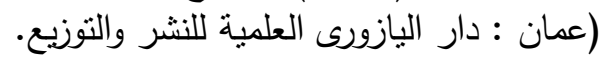

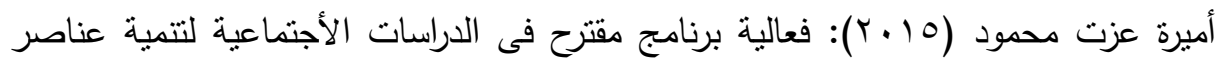

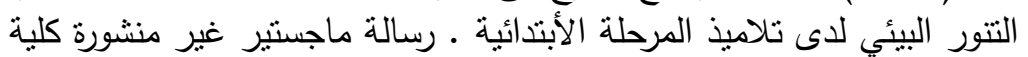

التربية. قسم الدراسات الأجتماعية ـ جامعة الأبنائة المنصورة.

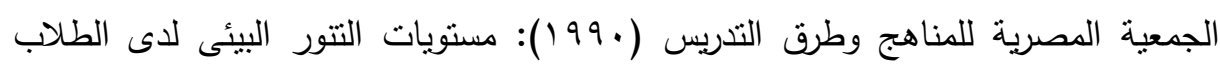

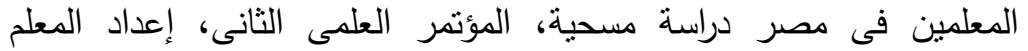

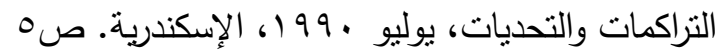

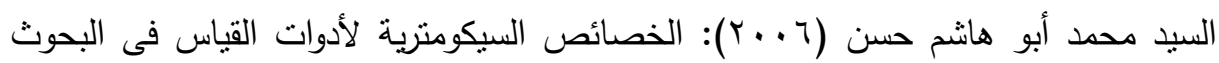

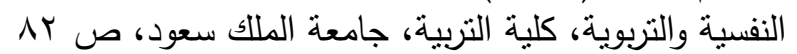

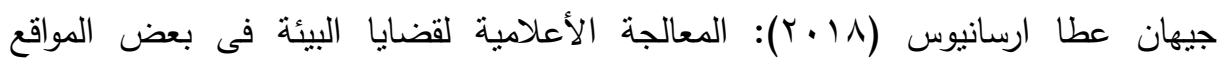

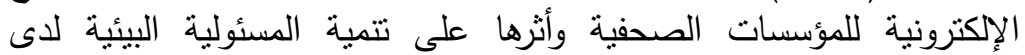

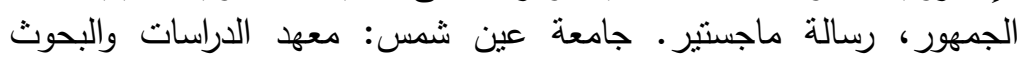

$$
\text { البيئية، قسم العلوم التربوية والأعلام البيئى. }
$$

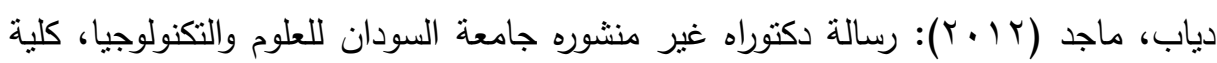
الفنون الجميلة. صنالة صكاه

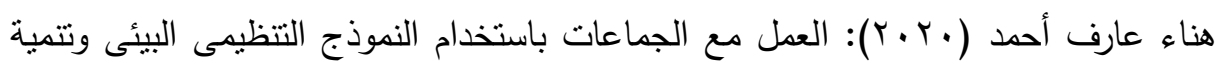

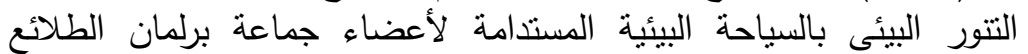
بمدينة أسوان، مجلة دراسات فى الخدمة الأجتماعية والعلوم الأنسانية، ب( (0) إبريل.

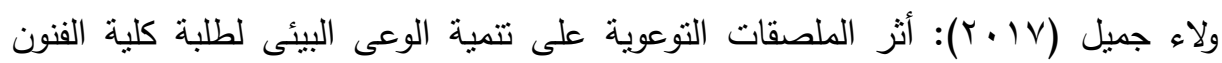

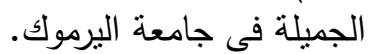

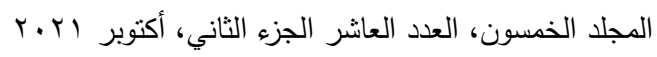

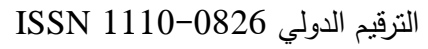

$$
\begin{aligned}
& \text { الترقيم الدولي الموحد الإلكتروني 3178-2636 }
\end{aligned}
$$




\section{مجلة العلوم البيئية \\ كلية الدراسات العليا والبحوث البيئية - جامعة عين شمس لبيه \\ مريم جورج عبد الثهيد وآخرون}

حسام قرعان (10 ب ب): ترجمة حسام قرعان، اساسيات التصميم الجرافيكى الطبعة الأولى،

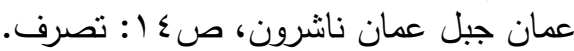

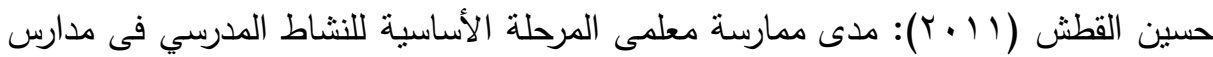

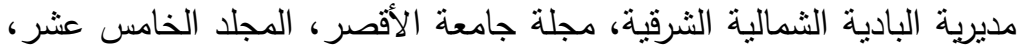

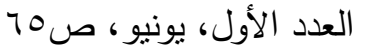

حسن شحاته (99 (19): النشاط المدرسي: مفهومة ووظائفة ومجالات نطبيقة، طا، الدار المصرية اللبنانية، القاهرة. ص10 المباط

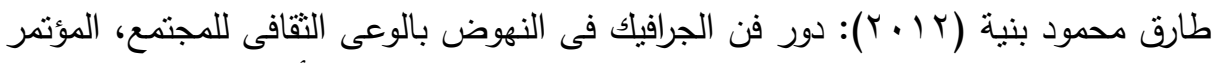

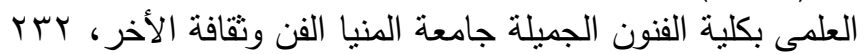

محمد المنيف (797 (1)): النشاط المدرسي المنهجى واللامنهجى مجلة التوثيق التربوى، عدد

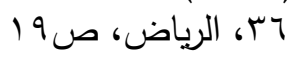

محمد صابر سليم (1990): مرجع فى التربية البيئية دراسات حالة لإثراء المناهج التعليمية صنية بيئيا، مشروع التدريب والوعى البيئى دانيدا، جهاز شئون البيئة، رئاسة مجلس الئس الئس

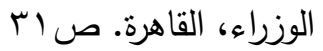

ميلاد وليم واصف (Y V V Y): تتمية التتور البيئى لمعلمات رياض الأطفال باستخدام

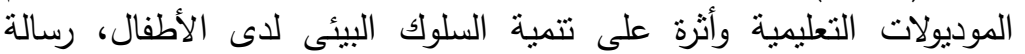

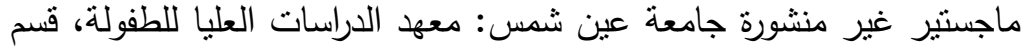
التربية والعلوم البيئية.

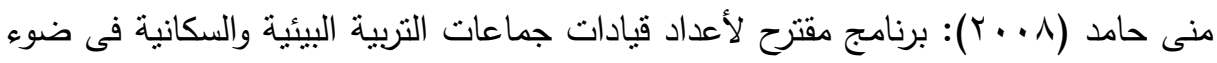

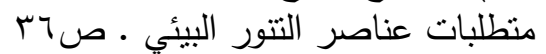

نادية محمد العطاب (7 ( †): فاعلية مقرر التربية البيئية فى تحقيق إتجاهات إيجابية بيئية لاى طلبة قسم الكيمياء بالجامعة.

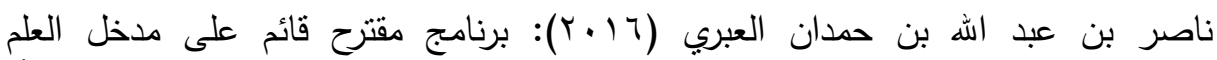

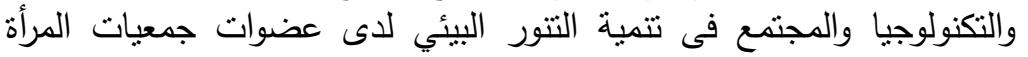

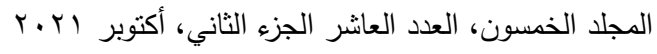

$$
\begin{aligned}
& \text { الترقيم الدولي 0826- ISSN 1110 } \\
& \text { الترقيم الدولي الموحد الإلكتروني 3178-2636 }
\end{aligned}
$$


العمانية، رسالة دكتوراه غير منشورة، معهد الدراسات والبحوث البيئية، قسم

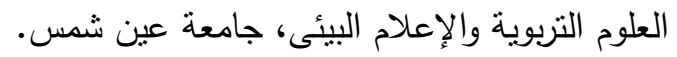

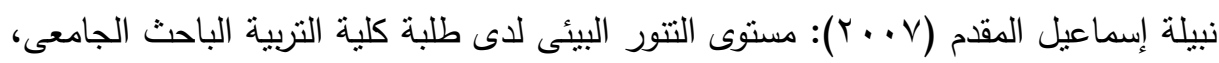
جامعة إب، يناير المان.

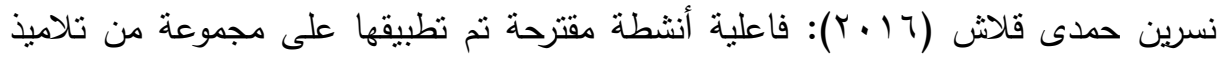
الصف الثانى الإعدادى فى تتمية الإتجاهات نحو الدحافظة على البيئة.

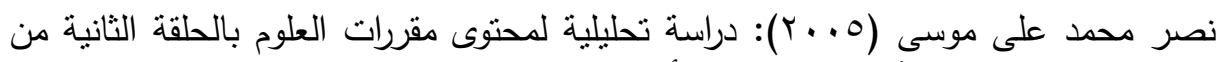

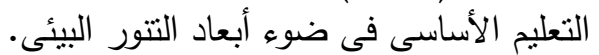

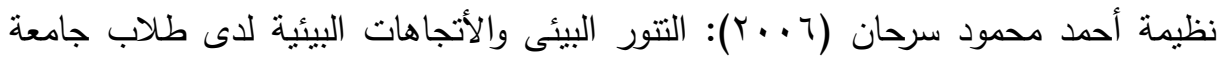
حلوان برنامج مقترح لتنمية التنور البيئى والأتجاهات البيأنياتية.

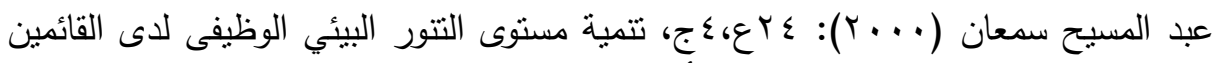
بالتدريس بفصول محو الأمية، مجلة كلية التربية، جامعة عين شمس.

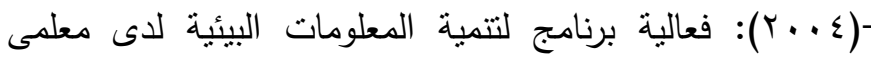

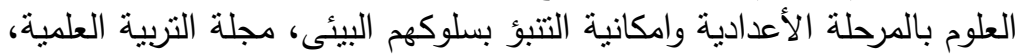

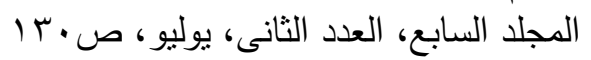

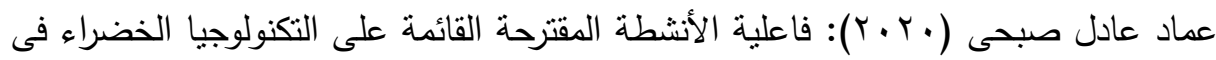
تتمية نتور التلاميذ بمفاهيم التكنولوجيا الخضراء من حيث الإنية زيادة معلوماتهم

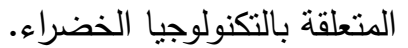

عصام توفيق (0 . ب): الأنشطة المدرسية والوعى البيئي : الأطر النظرية - الادوار الوظيفية

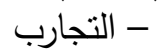

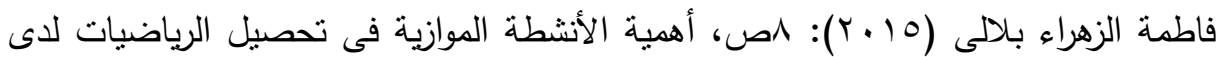
طلاب التعليم الثانوى الإعدادى، فاس، المركز الجهوى لمهن التربية والتكوين فلين لإني

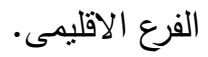

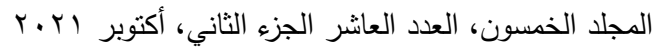

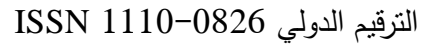

$$
\begin{aligned}
& \text { الترقيم الدولي الموحد الإلكتروني 3178-2636 }
\end{aligned}
$$




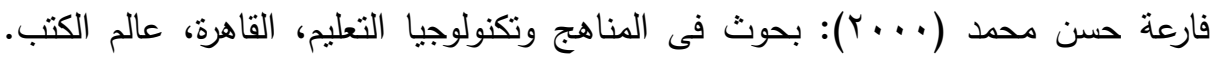
ص. מ. מ

صابر سليم وأخرون (999 (1)): مرجع فى التربية البيئية للتعليم النظامى وغير النظامى مشروع بلئي

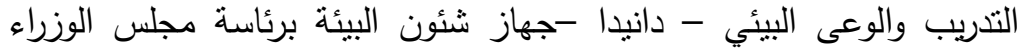

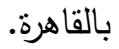

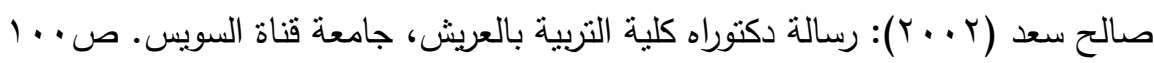

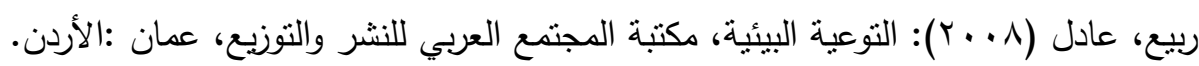

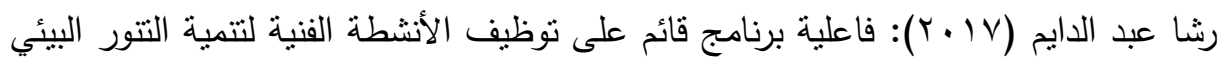
لطفل الروضة حيث تمكن طفل الروضة من التعرف على التى المشاكل البيئية بعد تطبيق البرنامج عليه.

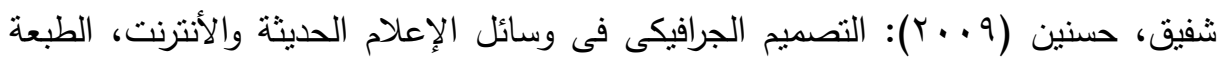

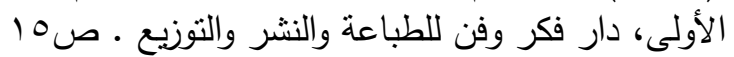

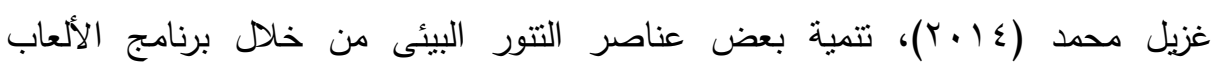
الإلكترونية لاى تلميذات المرحلة الأبتدائية بدولة الكويت.

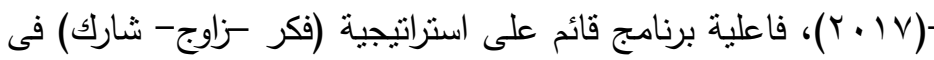
تتمية القيم والمهارات البيئية لدى تلميذات الماتية المرحلة المتوسطة بدولة الكويت.

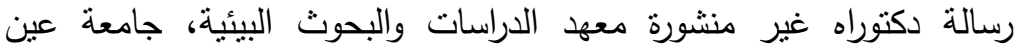
شمس.

غيث، خلود (1) (1) مدخل إلى التصميم الجرافيكى الطبعة الأولى، عمان: دار الإعصار للنشر والتوزيع والإعلان بين النظرية والنطبيق.

Bamberg, S. and Moser, G. (2007): Twenty years after hines, Humgerford and to mera: Anew meta-analysis of psychosocial determinants of pro -environ mental behavior. Journal of environmental psychology, vol.27, p.14-25. 


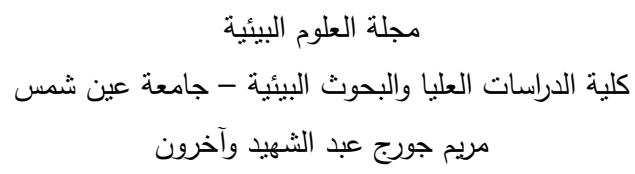

Cottrell, S. P. et al. (1993): General Responsible Environ mental Behavior Among Boaters on the Chesapeake Bay. Northeasterm Aecreation Research symposium, Saratoga sprimgs, NY.

Gheith, E. (2019): Environmental Litercy among prospective classram teachers im jordan, international journal of learning, teaching and educational research 8(12), 258-279, https://doi. Org/10.26803/ij/ter,18.12.15

Emmanuel, Chukwuemeka (2017): Environmental Journalism and National sustaimable Development in Nigeria: an analysis, department of mass communication ,federal polgtechnic nekede, owerri.2, 190-194.

Humgertard, H. (1980): Peyton R. Aparadign forcitizen Responsibility: Environmental action, in A. Sack, et al; (eds.) current issuesvI; the year book of environ mental education and environmental studies (pp. 14-154)

Jennifer Gibbons (2016): The link between Extracurricular Activities and development of some dimensions of emvironmantal literacy for youth in Grades 5 and studies in education for the degree of master of education, Faculty of education.

Philip kotler. P. and Others (1999): Principles of marketing" (enligne), $2^{\text {nd }}$ ediition, jernew, USA: premtice hall Europe, $p, 793$.

Lioyd-strovas, J. Moseley, C, Arsuffi, T. (2018): Environmental literacy of under graduate college students: development of the environmental literacy instrument LE(1). School science and Mathematics, 118(3-4),84-92.

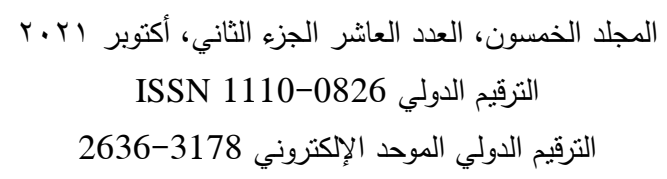




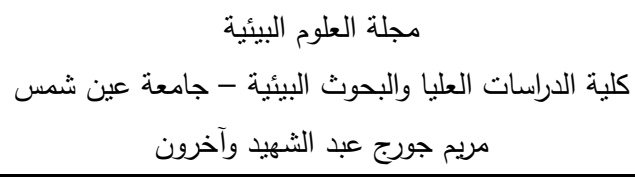

Monroe, K. B. and others (2004): Perceived price umfairness of dynamic pricing and its Freegift to study comsumers, perceptions and behaviors, behavioral.

Peer, S.; Goldman, D. and Yavetz, B. (2007): Environmental Literacy in teacher training: attitudes knowledge and environmental behavior or begimning students the journal of environmental Education, 39(1), 45-59.

Shin Jang Hus (2004): The Effect of an environmemtal education program of responsible environmental of behavior and Associated emvironmental literacy variables in Taiwanese college students education optic, pp.34-48

Sheneff, David J - Vandell, Deborah (2018): youth engagement and quality of Experience in after schoal occasional paper series.

Shirey, J. (2011): Designing for bwhavior change: identifying design components that encourage and empower in dividuals to act in environmentally responsible ways- carmegie mellon university (moster thesis of design)

Weizer. B. (2011): The Enviro thon and its effect on students environmental literacy. Edd, University of Hounton, voulusse g2-09a dissertation abstracts international,p.29

Roth, Charles (1992): Environmental literacy: its roots, Evolution,and directions in the 1990s, Columbus, OH: ERIC Clearinghouse for science, Mathematics and environmental Education (ERIC Document Reproduction Service no . ED348 235)

Unesco-unep, (1990): Environmental literacy for all, connect, environmental education news letter, no.(20) ,pp. 1-2

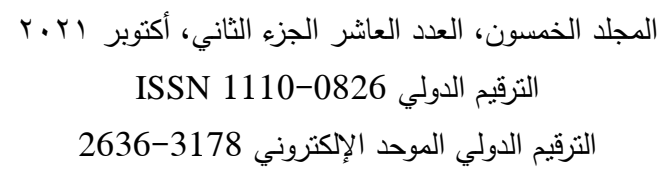




$$
\begin{aligned}
& \text { مجلة العلوم البيئية } \\
& \text { كلية الدراسات العليا والبحوث البيئية - جامعة عين شمس لئه } \\
& \text { مريم جورج عبد الثهيد وآخرون }
\end{aligned}
$$

Stapp, Williams B. and Darothy A. Cox (1974): Environmental Educatian Activites Manual volume 1, comcering space ship estn", op. cit,p.

\title{
USING ART OF GRAPHICS FOR PRODUCING GUIDING MEANS FOR DEVELOPING ENVIRONMENTAL LITERACY AMONG PREPARATORY SCHOOL STUDENTS
}

\section{Mariam G. Abdel Shaheed ${ }^{(1)}$; Abdel Messeh S. Abdel Messeh (2) and Morad H. Babawy ${ }^{(3)}$}

1) Post graduate student at Faculty of Graduate Studies and Environmental Research, Ain Shams University 2) Faculty of Graduate Studies and Environmental Research, Ain Shams University 3) National Center for Educational Research

\begin{abstract}
This researchs' purpose is to develop environmental literacy through the use of graphic art for preparatory stage students through the design of guiding means. Therefore, the researchers have prepared a list of some environmental problems by reviewing some previous research and studies and the opinions of specialists which have included (5) major issues branching from them (9) environmental problems, which in turn have included (43) concepts. The researchs tools are prepared to include (6) posters with different designs, a brochure with two covers, the design of (2) (folded) magazines, a design of the cover of the face and the back of the notebook. Inside it, contains a number of recycled

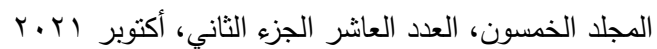

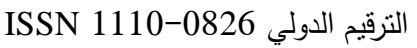

$$
\begin{aligned}
& \text { الترقيم الدولي الموحد الإلكتروني 3178-2636 }
\end{aligned}
$$




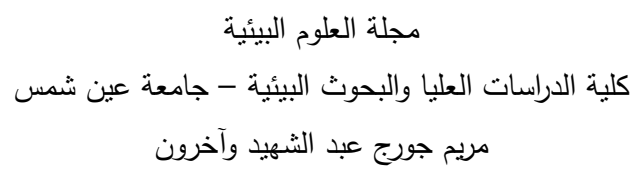

paper, the design of one desk-calendar which contains 12 designs; inside it, there is a folder design for keeping papers, a CD sticker design, a card design, a design of 4 prints on Cochet paper, environmental games, printing on a mug, printing on a paper folder. A scale of Environmental Literacy has been also designed, including (a Test of Environmental Information, a Scale of Environmental Attitudes and a Scale of Environmental Skills). A program of the proposed activities has been applied to a group of (30) students of the second year of preparatory school. The experimental method has been used for its suitability to the nature of this research. After the application of the guiding means program, a post-application of the scale of environmental literacy has been subsequently conducted to the research group.

Results indicate that the average scores of the experimental group has increased after the statistical treatment of these scores and that: There is a statistically significant difference between the mean scores of students on the scale of environmental literacy pre/post application of the guiding means, in favor of the post-application. There are also statistically significant differences regarding the scores of each dimension of the environmental literacy dimensions pre/post application of the program, in favor of the post-application. This indicates the effectiveness of the program of the guiding means produced using graphic art for the development of environmental literacy. The researcher recommends the necessity of including the guiding means designed using graphic art in the schools of the preparatory stages and using the means that have been designed as well.

Keywords: Graphic art - Environmental literacy - Guiding means.

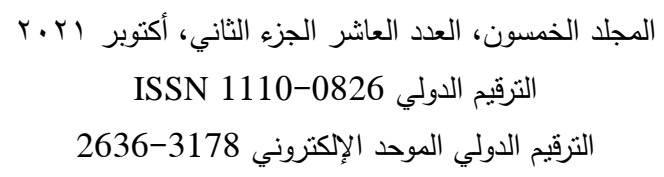

